Andrews University

Digital Commons @ Andrews University

1978

\title{
A Training Program for Leadership in Group Processes Designed to Help Establish New Members in the West Indies SDA Churches
}

John C. Palmer

Andrews University

Follow this and additional works at: https://digitalcommons.andrews.edu/dmin

Part of the Practical Theology Commons

\section{Recommended Citation}

Palmer, John C., "A Training Program for Leadership in Group Processes Designed to Help Establish New Members in the West Indies SDA Churches" (1978). Professional Dissertations DMin. 214.

https://dx.doi.org/10.32597/dmin/214

https://digitalcommons.andrews.edu/dmin/214

This Project Report is brought to you for free and open access by the Graduate Research at Digital Commons @ Andrews University. It has been accepted for inclusion in Professional Dissertations DMin by an authorized administrator of Digital Commons @ Andrews University. For more information, please contact repository@andrews.edu. 


\section{ABSTRACT \\ A TRAINING PROGRAM FOR LEADERSHIP IN GROUP PROCESSES DESIGNED TO HELP ESTABLISH NEW MEMBERS IN THE \\ WEST INDIES SDA CHURCHES}

\section{by}

John C. Palmer

Chairperson: Arnold Kurtz 


\author{
ABSTRACT OF GRADUATE STUDENT RESEARCH \\ Project \\ Andrews University \\ Seventh-day Adventist Theologica1 Seminary.
}

Title: A TRAINING PROGRAM FOR LEADERSHIP IN GROUP PROCESSES DESIGNED TO HELP ESTABLISH NEW MEMBERS IN THE WEST INDIES SDA CHURCHES

Name of research: John C. Palmer

Name and title of faculty adviser: Dr. Arnold Kurtz, Ph.D.; D.Min. Date completed: June 1978

\title{
Problem
}

To develop a program specifically aimed at integrating new converts into the church family in the churches of the West Indies Union Conference of Seventh-day Adventists.

\section{Method}

The method employed in the prosecution of this project consisted of the following activities:

(1) Review and evaluation of the relevant theological and instructional 1iterature.

(2) Organizing and structuring the relevant material in a training course design for ministers of the West Indies Union 
Conference of Seventh-day Adventists.

(3) Conducting, first a pilot scheme in group leadership on the campus of Andrews University, and then conducting this training course on the campus of West Indies College in Mandeville, Jamaica.

(4) Evaluating the course.

\section{Results}

(1) The high degree of group cohesion attained, both socially and spiritually suggests that the objective of the course was satisfactorily achieved in the development of that quality of fellowship that is referred to in the New Testament as koinonia.

(2) The total group response indicated positively the members' satisfaction as well as the fulfillment of group goals.

(3) The group members were unanimous in expressing their eagerness to implement the new concepts and group skills in their churches for a more effective ministry.

\section{Conclusion}

As a result of the formative evaluation and other instruments in the form of questionnaires administered in the project it seems reasonable to conclude:

(1) That the true spirit of koinonia can be developed among Seventh-day Adventist church members in this territory in a relatively short time.

(2) That within the context of a mutual member-to-member ministry, a genuinely caring ministry on the part of old members towards new members could be satisfactorily developed under the guidance of pastors who have had the necessary training. 
(3) That the Seventh-day Adventist pastors of this territory appear to be eager to cooperate with any genuine program that promises not only to increase evangelistic gains but also to enhance membership conservation by consolidating their evangelistic gains. 
Andrews University

Seventh-day Adventist Theological Seminary

A TRAINING PROGRAM FOR LEADERSHIP IN GROUP PROCESSES DESIGNED TO HELP

ESTABLISH NEW MEMBERS IN THE

WEST INDIES SDA CHURCHES

\author{
A Project Report \\ Presented in Partial Fulfillment \\ of the Requirements for the Degree \\ Doctor of Ministry
}

by

John C. Palmer

June 1978 



\title{
A TRAINING PROCRAM FOR IEADERSHIP IN GROUP PROCESSES DESIGNED TO HELP \\ ESTABLISH NEW MEMBERS IN THE WEST INDIES SDA CHURCHES
}

\author{
A project presented \\ in partial fulfillment of the requirements \\ for the degree \\ Doctor of Ministry
}

by

John C. Palmer

APPROVAL BY THE COMMITTEE:

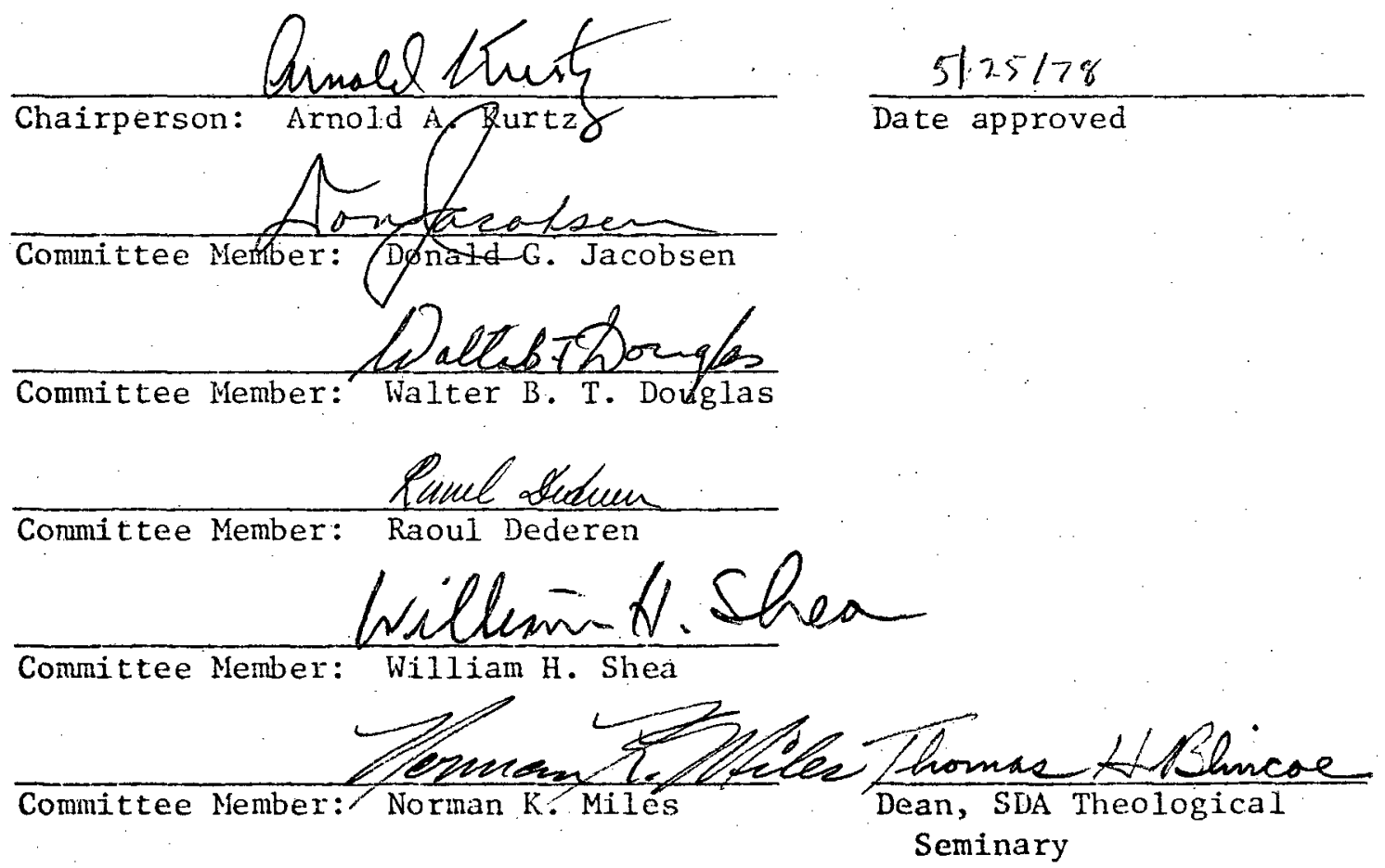


LIST OF TABLES • • • • • • . • • • • • • • • • • •

ACKNOWLEDGMENTS . . . . . . . . . . . . . . . . v vii

Chapter

I. INTRODUCTTON .. . . . . . . . . . . . . . . 1

The Need ..................... . . 1

Statement of the Problem ............. 2

Purpose ...................... 5

Expectations .................. . . . . . 7

Long-range Objectives ............. . . . . 7

The Church . . . . . . . . . . . . 7

New Converts . . . . . . . . . . . 8

Evangelism .................. 9

Short-range Objectives ............ 9

Pastors.................. 9

Personal .. . . . . . . . . . . . 9

Significant Terms ............... 10

Description of the Project . . . . . . . . . 12

Overview of Study . . . . . . . . . . . . 13

II. THEOLOGICAL FOUNDATIONS . . . . . . . . . . . . . 14

A Theology of the Laity . . . . . . . . . . 14

Church .................... 15

An Act of God .. . . . . . . . . . . . . . 16

Community of the Redeemed ............. 16

The Priesthood of Believers . . . . . . . . . 17

The Ministry of the Laity . . . . . . . . . 19

The Role of the Pastor ............. 22

Purpose of the Church . . . . . . . . . . . 23

Missio Dei ................... . . . 24

The Symbol of the Kingdom . . . . . . . . . 25

The Church an Implement of Salvation........ 26

Toward a Theology of Relationship . . . . . . . . . 29

Humanity's Need for This Relationship . . . . . . . . 31

Koinonia Distinguishes the Christian Community . . 32

Importance of Christian Community for Individual
Growth . . . . . . . . . . . . . . . 35

Community Contributions Through Smal1 Groups . . . . 36

Self-discovery .. . . . . . . . . . 36

Self-acceptance ............. . . 37

Incarnate Love . . . . . . . . . . . . . 37

Healing . . . . . . . . . . . . . . 38 
Wholeness .............. . . 39

Intercessory Prayer .............. 40

Growth .................. . 41

Sense of Mission ............. . . 42

Fellowship of the Holy Spirit . . . . . . . . 42

III. THE SMALL GROUP PHENOMENON--ITS CHALLENGES AND

POSSIBILITIES FOR THE CHURCH . . . . . . . . . . 45

Relationship ................. . . 4 47

The Missing Dimension in the Family .. . . . . . 47

The Missing Dimension in Society . . . . . . . 48

The Missing Dimension in the Church .. . . . . . . 51

Possibilities for the Church . . . . . ... . . 53

Christianity Supplies the Key . . . . . . . . 55

Potential for Church Renewal and Revitalization . . 56

Necessity for Training . . . . . . . . . 57

IV. PROJECT DESCRIPTION . . . . . . . . . . . . . . 60

Pilot Program . . . . . . . . . . . . . 60

Approval of Institutions . . . . . . . . . . 61

Description of Course . . . . . . . . . . . . 61

Course Agencia................ . . . 62

General Information . . . . . . . . . . 62

Course Design... . . . . . . . . . . . 65

The Daily Class Sessions . . . . . . . . . 66

Summary of Course Content and Activities . . . . . 66

Self-actualization, Days 2 and 3 . . . . . . 66

Self-disclosure, Days 4-6........... . 70

Self-transcendence, Days 7-10........ 82

V. EVALUATION, IMPLICATIONS, CONCLUSION, AND

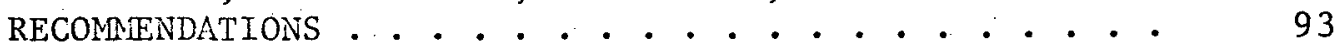

Evaluation of the Project . . . . . . . . . 93

The Formative-evaluation Process . . . . . . 94

Likert-type Attitude Test . . . . . . . . . 94

Questionnaire Evaluation and Analysis....... 95

Implications . . . . . . . . . . . . . 110

For the Church ................. 110

For the Writer ............... 115

Conclusion ................... . . . . 116

Recomendations . . . . . . . . . . . 117

APPENDIX A. Sanple of a Typical Class Lecture . . . . . . 119

APPENDIX B. Sumary of Instructional Concepts Used in Lectures on Self-disclosure and Selftranscendence . . . . . . . . . . . .

APPENDIX C. Exercises Used in Lab Sessions . . . . . . . . . 138 
APPENDIX D. Hand-outs . . . . . . . . . . . 157

BIBLIOGRAPHY . . . . . . . . . . . . . . 183

$\operatorname{VITA~.~.~.~.~.~.~.~.~.~.~.~.~.~.~.~.~} 193$ 


\section{LIST OF TABLES}

1. Evaluation of Group Leadership, Processes and Goals . . . 97

2. Evaluation of Group Relationship, Process and Goals . . . 99

3. Evaluation of Group Relationship, Processes and Goals . . 100

4. General Evaluation of the Group Leader . . . . . . . . 102

5. Evaluation of Group Process and Goals . . . . . . . . . 106 


\section{ACKNOWLEDGMENTS}

I am happy to acknowledge with grateful thanks ny indebtedness to all the kind folk who helped and encouraged me during my struggle on this campus to complete this course. My depth of gratitude, however, demands the naming of some persons in particular.

I would like to especially thank Pastors H. S. Walters of the West Indies Union Conference and B. L. Archbold of the Inter American Division for making it possible for me to return to Andrews to pursue this course; Dr. Walter Douglas, assistant professor of church history, and history of antiquity, in whose class I was first introduced to the group approach in the learning situation and who served as one of my advisors; Dr. Don Jacobsen, associate professor of evangelism, and personal nurture, whose class deepened my impression of the group concept and who also served as one of my advisors; Dr. Steven Vitrano, professor of preaching, and field education, for his hours of counsel and guidance; and Dr. Raoul Dederen, professor of historical theology, for his invaluable assistance in the theological area. Others that must be mentioned are Drs. W. Murdoch, E. Chalmers, B. Reeves, and G. Oosterwal, Miss Sirley Welch, and Mrs. Carmen Holland.

My greatest debt of gratitude, however, must be reserved for my major professor, Dr. Arnold Kurtz, professor of church leadership and administration of church organization, and my wife, Ina May. It was through the influence and inspiration of Dr. Kurtz, chairman of 
the Doctor of Ministry program, though unknown to him, that the "die was cast" in my choice of this particular project and from his c1asses I gleaned ideas and material that laid the foundation for the project. Added to this was his kind patience in working with me painstakingly throughout the entire project, as chairman of my advisory committee. Ina May not only spent sleepless nights editing and typing this manuscript, but assumed the responsibility of "bread-winner" for most of the years I spent in obtaining my education from the B.A. to the D.Min., at the same time earning her M.A. in educational administration. All the congratulations belong to you, May.

Last and greatest of all is my inexpressible gratitude to my heavenly Father who, by His great mercies, has brought me from a "mighty long way." 


\section{CHAPTER I}

\section{INTRODUCTION}

\section{The Need}

As evangelist and ministerial secretary of the West Indies Union Conference of Seventh-day Adventists, the writer has been deeply concerned for many years with the problem of membership attrition in this territory, particularly of the new members, and with the apparent lack of meaningful fellowship in the church.

After years of observation as pastor and as evangelist, augmented by personal interviews and discussions with church members, pastors and denominational officers, the conviction has grown that there is a keenly felt need in this territory to develop an awareness of the responsibility of members to one another.

Other factors accentuating the urgency of this need are as follows :

(1) The ratio of pastors to church members in this union conference, which at present is approximately 1 to 1,200 (the average district is six churches), necessitates such a program of caring ministry among believers.

(2) The problem of membership attrition seems to indicate the necessity for a program to strengthen church members with special emphasis on the stabilization of the new converts.

(3) Poor interpersonal relationships point to the need for 
establishing and developing "the fellowship of the saints" (koinonia) and the communion of the Holy Spirit in a practical way.

This missing dimension in the church has been confirmed and highlighted by Gottfried Oosterwal's discovery in his recent research on Seventh-day Adventist Church growth in North America:

In the churches that show 1ittle or no growth, over 70 percent of the people who responded to the question as to what aspects of their church could be improved included 'more fellowship.' in their answers, a much higher percentage than any other need for improvement. 1

The findings of this research in regards to the spiritual "culture shock" ${ }^{2}$ which new believers suffer, and their disappointment in not finding warm fellowship in the church, is by no means peculiar to North America. The writer's twenty-five years of pastoral experience in this territory attest to this fact.

One of the greatest challenges, therefore, that confronts the church today is to "discover... . what structures, programs and organizations can best fulfill this need for communion and fellowship. ${ }^{3}$

\section{Statement of the Problem}

At present there is no definite program in the Seventh-day Adventist Church in the West Indies Union Conference that is specifically aimed at integrating and stabilizing new believers into the church family. There is no specific program that is addressed to the problem of orienting these new converts into the Seventh-day Adventist

$1_{\text {Gottfried Oosterwal, Patterns of SDA Church Growth in }}$ America (Berrien Springs, Mich.: Andrews University Press, 1976), p. 53 .

${ }^{2}$ Ibid., p. $51 . \quad$ 2Ibid., p. 26 
life-style after they have been stripped of their former way of life and affiliations. There appears to be a need for positive, systematic, caring fellowship to nurture them into spiritual development.

Consequent1y, many new converts suffer keen disappointment

in not finding this quality fellowship and eventually return to their former life and their old associations.

This lack of a definite plan or system of spiritual "postnatal care" of these new born babes ${ }^{1}$ (new converts) as contrasted with the "prenatal care" (evangelistic preparation) surfaces in the general attitude of older members toward new members ${ }^{2}$ where a meaningful relationship is concerned. Norman Wegmeyer's observation is pertinent :

Like our Lord, we all have degrees of relationships, but we ought to learn the importance of cultivating such relationships in the church. Oddly, while the church is essentially relationships and while relationships are built on personal communication, it is unfortunately true that we tend to shy awąy from personal communication in connection with the church. ${ }^{3}$

If it is true that "A mother calls the personality of the

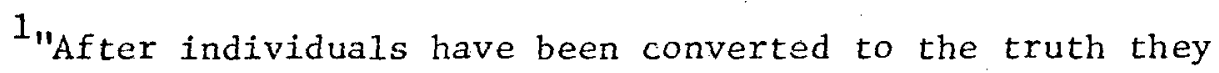
need to be looked after. The zeal of many ministers seems to fail as soon as a measure of success attends their efforts. They do not realize that these newly converted ones need nursing--watchful attention, help and encouragement.

"No wonder that some become discouraged, linger by the way, and are left for wolves to devour. Satan is upon the track of all. He sends his agents forth to gather back to his ranks the souls he has lost. There should be more fathers and mothers to take these babes in the truth to their hearts, and to encourage them and pray for them, that their faith be not confused." Ellen G. White, Evangelism (Washington, D.C.: Review and Herald Publishing Association, 1946), pp. 351-52.

2 Oosterwal, p. 26 .

3 Norman E. Wegmeyer, The Art of Christian Relationships (Minneapolis: Augsburg Publishing House, 1976), p. 19. 
child into being by communicating with him," $"$ and if it is true that "people communicate all the time in all relationships" intentionally or unintentionally, ${ }^{2}$ verbally or nonverbally (even by remaining silent), then it must be true that the church through its older members is communicating a constant series of nonverbal messages to the new converts. These messages may be interpreted as saying, "We are really not interested in you as a person, nor greatly concerned about your spiritual well-being per se, only in your addition to the church register and your financial contribution to its program." 3

The problem, therefore, in simple terms is how to develop this kind of meaningful, caring fellowship in the church, especially in large churches; what structure (or restructuring) can be devised and developed in the church that will be designed specifically not only to win, but to hold new believers by satisfying this deep need. On solution to the problem is to establish a genuine fellowship in the church by improving interpersonal relationships through the small group communication process. The following excerpt from Wegmeyer supports this need for inter-member communication:

If relationships are important in the church, then it is also important that there be opportunity and encouragement for comnunication between the members of the church. Without

${ }^{1}$ Harvey Siefert and Howard H. Clinebell, Jr., Personal Growth and Social Change (Philadelphia: Westminster Press, 1952), p. 110.

2 ${ }^{2}$ Ibid., p. 112 .

3". . we neglect them altogether once they are in the church. This is one reason why we have such a problem with losses among those whom we win through our evangelistic endeavors." Reuben A. Hubbard and Kathy Hargrave, "Don't Stop With Community Programs," Ministry, August 1977, p. 20. 
communication there will be no relationships, and without personal relationships there is no church--only a collection of people. ${ }^{1}$

speaking of this need for communication ${ }^{2}$ in establishing relationships, Ruel Howe makes it even more urgent: "Dialogue is to love what blood is to the body." ${ }^{3}$ That is to say that dialogue or real communication is the foundation of meaningful relationship: "Indeed, this is the miracle of dialogue; it can bring relationship into being, and it can bring being once again into a relationship that has died."

\section{Purpose}

The purpose of this project was to develop and implement a minj.sterial institute for the pastors of the West Indies Union Conference for the purpose of training them and helping them to train leaders of small groups in which the concept of mutual member-to tiember ministry might be realized. The ultimate reward of this program in terms of ministry were to:

(1) Integrate and stabilize the new converts within the church family.

$1_{\text {Wegmeyer, p. } 13 .}$

${ }^{2}$ Hobart Mowrer, emeritus professor of psychiatry at the University of Iilinois, once described himself as having "a lover's quarrel with the church." He explained that the church had failed him when he was a teenager and has continued "to fail his patients today. How? Because the church has never learned the secret of community." John R. W. Stott, "Unhooked Christians," Christianity Today, October 7, 1977, pp. 40-41. 1963), p. 3.

${ }^{3}$ Ruel Howe, The Miracle of Dialogue (New York: Seabury Press, ${ }^{4}$ Ibid. 
(2) Stimulate spiritual growth and development of church members .

(3) Provide an alternate means of evangelistic outreach.

Since the church, possibly more than any other institution, is involved with small groups in various forms, a conceivable by-product of this course has been the new insights and skills for pastors and church elders that will enable them to make their church board meetings, school boards, Sabbath School councils, and other task-oriented groups of the church more productive and spiritually satisfying. 1

It was hoped that the overall effect of this program would serve to supply what to the writer seems to be the missing dimension in the Seventh-day Adventist Church: that quality of fellowship that (1) develops in the members a strong sense of "ownership" of the church and its mission; and (2) develops a strong sense of "beionging," first to God as His "peculiar possession" through a special relationship and then to one another as an integral part of the special fellowship (koinonia) that characterizes the christian community. Members will thus learn to recognize that the ultimate purpose of the church is to make effective the redemptive fellowship of her Lord rather than merely to provide opportunities for religious and social gatherings.

The following words express the writer's conviction:

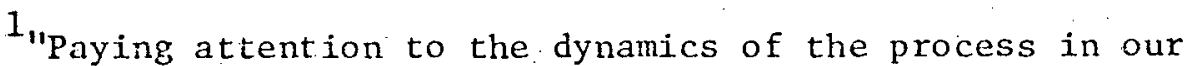
meetings gives us a concrete way of improving our relationships with one another and being reconciled to one another." Philip A. Anderson, Church Meetings That Matter (Philadelphia: United Church Press, 1965), p. 22 . 
The chief business of the church is to help all men grow in relationship with Jesus Christ and with each other. . . This means that the strengthening of relationships in the church is the work of the church. And when members of the body plan and pray, study and work together to serve the world for which Christ died and rose again, stronger relationships will develop.

This seems to be sufficient reason why it is incumbent upon us to improve our relationship with one another in the church, ${ }^{2}$ thus improving our effectiveness as witnesses for Christ in the world.

\section{Expectations}

It was hoped that the following objectives would be realized:

\section{Long-range objectives}

The church

(1) The establishment of a definite program in the church to foster and develop a true sense of koinonia, i.e., a fellowship that learns to share, "bearing one another's burden."

(2) That this program would foster and encourage a member-tomember mutual ministry within the context of small group fellowship, thus making practical the doctrine of the priesthood of believers (the universal priesthood) in the church.

(3) That this program would be instrumental in enhancing the effort of the church to recapture the spiritual zest and vitality ${ }^{3}$

${ }^{1}$ Wegmeyer, p. 7.

${ }^{2} \mathrm{~A}$ cold, critical attitude on the part of the members in a certain church, coupled with their lack of communication, drove a young man out of the church twice. He never again returned despite endearing entreaties. Cliff Snith, "The Encounter," Review and Herald, July 18, 1977, pp. 5, 6 .

3 "There is no question about the need for redeeming fellowship groups today. The sharing group offers the potential for meeting that need at the same time that it suggests a model for revital- 
of the New Testament church through koinonia (fellowship), diakonia (service), and kerygma (proclamation). ${ }^{1}$

(4) That as an indirect result of this program involving group procedures, task-oriented groups of the church, e.g., church board, school: board, business meetings, and other committees would become more productive and spiritually satisfying.

(5) That this mutual ministry of member-to-member led by small group leaders rightly trained would augment the pastoral ministry of the professional clergy, thus alleviating the pressure of over-burdened ministers in this territory.

New converts

(1) That the development of a definite and systematic program based on koinonia for integrating and stabilizing new converts into the church family would be realized.

(2) That this member-to-member mutual ministry generated and fostered by the warm, Christian fellowship (koinonia) of a genuinely caring community would be effective in attracting and holding new converts, thus helping to reduce the incidence of member dropouts. ${ }^{2}$

izing the life of the church." R. C. Leslie, Sharing Groups in the Church (Nashville: Abingdon Press, 1971), p. 199.

${ }^{1} \mathrm{~J}$. C. Hoekendijk, The Church Inside Out (Philadelphia: Westminster Press, 1964), p. 42.

2 "The Lord will put it into the hearts of His servants to welcome these trembling, repentant ones to their loving fellowship. - . Bring them into association with experienced Christians, that they may gain spiritual strength." Ellen G. White, Ministry of Healing (Nountain View, Calif.: Pacific Press Publishing Association, 1942), p. 178. 
Evangelism

It was hoped that a possible by-product developing from this project would be that these groups would provide a means of evangelistic outreach focusing on those people who are not being reached by other evangelistic methods.

\section{Short-range objectives}

Pastors

The greatest expectation of the writer was that as an immediate and direct result of the project:

(1) The participating pastors would catch a clear vision of the benefits and possibilities of the small group approach.

(2) Their zeal and enthusiasm would fire them to make and accelerate plans to introduce the group concept in their churches at the earliest opportunity.

It was also hoped that as a result of the new insights gained in group procedures the participants would

(1) Be able to make their committee meetings and church board meetings more productive.

(2) Improve the interpersonal relationships in their churches.

(3) Enhance their general leadership ability.

Personal

The writer hoped to obtain for himself a deeper understanding, broader insights, and increased skills in developing and implementing an effective program for membership conservation for the West Indies Union Conference. 


\section{$\underline{\text { Significant Terms }}$}

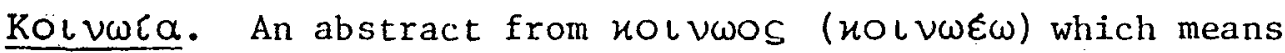
"fellows," "participants," and implies fellowship or sharing with

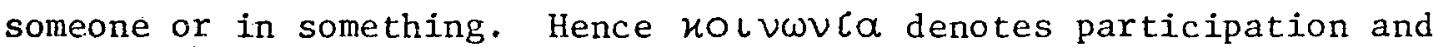
fellowship, especially with a close bond. It expresses a two-sided relation.

The nolvwvEw group is most common in Paul for whom it has the meaning of a direct religious fellowship (participation) of the believer in Christ and Christian blessings, and for the mutual fellowship of believers.

"In 1. John, Kolvwu Ca is a favorite term to describe the living bond in which the Christian stands. Here, too, the word implies inward fellowship as a religious basis." ${ }^{1}$

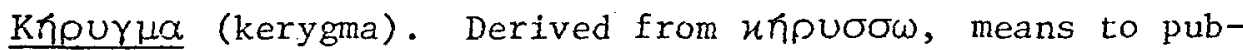
1ish, proclaim, announce open1: This is the act of proclaiming (1 Cor 2:4) or announcing. The content of the knourua focuses on the resurrection of Jesus Christ (1 Cor 15:14). By preaching is manifested the Logos which brings to man the eternal life that was promised. 2

"The unpurua is the mode by which the divine Logos comes to us. $" 3$

${ }^{1}$ Friedrich Hauck, "KolvwV in the NT," Theological Dictionary of the New Testament (Grand Rapids, Mich.: William B. Eerdmans Publishing Company, 1976), 3:807-8. (Hereafter abbreviated TDNT.)

${ }^{2}$ Gerhard Freidrich, "Knourua," TDNT (Grand Rapids, Mich.: William B. Eerdmans Publishing Company, 1976), 3:714-16.

3 Ibid., p. 716 . 
"Knoura is the announcement of the good news that Jesus is the Christ." 1

Slakovla. Derived from Slakovla "one who renders service to another." In the New Testament Slakovta means "waiting at table". or in a wider sense, "provision for bodily sustenance." It is also used for any "discharge of service" in genuine love. Thus the house of Stephanus gave itself to the service of the saints (1 Cor 16:15). A distinctive point for understanding this concept is that early Christians learned to regard and describe as stauovias al1 significant activity for the edification of the community (Eph 4:11).

The believer serves not only his brother but also Christ. He is responsible for the service committed to him as a gift of grace. In 1 Cor 12:28, Paul mentions the content of these acts of service, namely, acts of care and assiscance on behalf of the community.

Relationship. "Relationships are emotional connections between people, and the connections are made and sustained through communication." 2 This is vital for real fellowship.

Self-actualization. The psychological need for growth; development, and utilization of one's potential." 3

Self-disclosure. Occurs when one person reveals his true

$1_{\text {Thomas Oden, The Intensive Group Experience (Philadelphia: }}$ The Westminster Press, 1946), p. 9I.

${ }^{2}$ Wegmeyer, p. 12.

3 David Johnson and Frank Johnson, Joining Together: Group Theory and Group Skills (New Jersey: Prentice Hall, 1975), p. 289. 
feelings to another, who he is, and how he came to be this way. ${ }^{1}$

Self-transcendence. The word "transcendence" according to

Webster means "to go above or beyond, overpass, or exceed, as a limit; to go beyond in elevation, excellence, extent or degree." 2

Hence, self-transcendence implies going beyond the limits of self. Thus the word seems most expressive of the concept of selflessness that is basic to the qualities necessary for good group leadership. Self-interest must be subordinated to group interest.

\section{Description of the Project}

(1) This institute (training course) consisted of forty hours of lectures, discussions, and workshop activities dealing with the fundamental principles underlying the dynamics of the small group method for (a) stimulating spiritual growth of church members, (b) establishing new converts, (c) developing the koinonia (fellowship) among church members, and (d) evangelistic outreach.

(2) This institute was designed for pastors who will in turn train suitable small group leaders in their churches to implement this program which will be known as Operation koinonia.

(3) The West Indies Union Conference of Seventh-day Adventists and the West Indies College signified their desire for, and gave their support to this program (project).

(4) This program was tested locally as a pilot scheme before it was officially presented to the ministers.

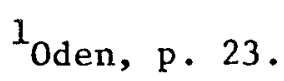

2 The Living Webster Encyclopedic Dictionary (Chicago: The English Language Institute of America, 1975). 
(5) Sources that were employed were: The Bible, the authoritative writings of the church, and other relevant literature in the field. The writer also consulted resource persons with competence in group procedures. Human resources were amply provided by the West Indies Union Conference of Seventh-day Adventists and the West Indies College.

\section{Overview of Study}

Obvious1y, any program designed to train and develop group leaders would necessarily involve a brief but comprehensive outline of the fundamental principles underlying group procedures. This seems basic to a proper grasp, on the part of the would-be leader, of the kind of relationship that is expected in the group situation. Hence, consideration was given to relevant instructional literature in group dynamics. The thematic structure of the study falls naturally under three main headings--self-acutualization, self-disclosure, and self-transcendence.

The remainder of this report is organized as follows:

In Chapter 2 a spiritual and biblical rationale for the concept of member-to-member mutual ministry based upon this concept of koinonia within the group context is offered.

Chapter 3 deals with the group phenomenon, its proliferation, and its challenges and possibilities for the church today.

Chapter 4 presents the description of the project in detail.

Chapter 5 presents an evaluation with implications, conclusions, and reconmendations. 


\section{CHAPTER II}

\section{THEOLOGICAL FOUNDATIONS}

The biblical doctrine regarding the laity seems most appropriate for establishing a theological perspective with respect to small groups in the church. Because of the various ramifications involved in this subject a theological concept commensurate to its scope and depth is required. This demand is met perfectly in the theological consept of the laity inasmuch as any discussion of a theology of the laity must necessarily involve such cognate areas ${ }^{1}$ as the nature of the church; of mission, and of the Christian relationship-areas directly related to the group concept. A theology of the laity, therefore, provides an appropriate theological umbrella for a doctrinal treatment of the training of group leaders for koinonia (fellowship) and other growth groups in the church.

\section{A Theology of the Laity}

A proper definition of the "laity" (in common parlance, lay membership) embraces the "totality of believers in the church." 2 Theologically it implies God's plan of salvation as unfolded in

$1_{\text {Hendrik Kraemer, A Theology of the Laity (Philadelphia: }}$ Westminster Press, 1958), p. 75 .

${ }^{2}$ George Eldon Ladd, A Theology of the New Testament (Grand Rapids, Mich.: William B. Eerdmans Publishing Company, 1974), p. 537 . 
redemptive history. ${ }^{1}$ The English term, laity, is derived from the Greek laikos which means "belonging to the laos," that is, "a body of people," "a concourse of people," or simply "people." 2 In Luke 2:32 it is used in reference to "the people of Israel" (1aou sou Israel); hence laos comes to mean "the people of God," and in this light laikoi refers to the members of this body or people. It may be observed that while the term, laikos, strictly speaking, is not found in the scriptures its meaning is nevertheless quite clear in reference to laos as the people of $\mathrm{God}^{3}$

A theology of the laity, then, refers to a study of "the people of God" in an endeavor to arrive at a proper understanding of the church and its purpose for existence in the world. ${ }^{4}$

\section{Church}

The English word, church, is derived from the Greek word, kuriakon, which means : that which belongs to the Lord." 5 The idea of the church as "the people of God" is conveyed by two Greek words, laos in contrast to ethne (or nations), and ekklēsia which is derived from ekkleoo (to summons). "The semantic value of the word is that of an assembly called together." ${ }^{6}$ Hence, an assembly or convocation,

${ }^{1}$ Ibid., p. 538 .

2 The Analytical Greek Lexicon (New York: Harper and Brothers Publishers, n.d.), p. 246 .

$$
3 \text { Kraemer, p. 155. } \quad 4 \text { Ibid., p. } 127 .
$$

5 Robert T. Handy, Members One of Another (Valley Forge: Judson Press, 1968), p. 60.

6 Yves Congar, Lay People in the Church (Maryland: Newman Press, 1967), p. 23 . 
as in Acts $7: 38$, where ekklésia is used for the congregation of the children of Israel. This accords with the characteristic Septuagint usages which imply "a people raised up by God" or "called out by God." The assembly exists on the basis of the act of God. 1

An act of God

This "act of God" in calling out a people from the nations of earth to be designated as specially $\mathrm{His}^{2}$ is not an idea peculiar to the 01d Testament. This concept is developed in the New Testament within a continum that dates back to the call ("election") of Abraham in the 01d Testament. ${ }^{3}$ "The act of election of Abraham (and implicitly of Israel) coincides with the promise or prospect of blessings for the nations." 4 To this end the covenant established with Abraham and subsequently with his descendants (the Israelites) as the special people of God $^{5}$ was intended, as Blauw states:

The history of Israel in her totality and in her context is universal prophecy. For the 01d Testament makes it unmistakably clear, again and again, that it is precisely the covenant of Yahweh with a unique Israel, of Israel with a unique God . . . far from being an end in itself, far from getting one wrapped up in this particular relationship--has meaning, revelation, real and dynamic import for the relation between God and all peoples, men of all peoples. 6

Community of the redeemed

The idea of the church as a community of believers is also derived from the Greek usage of ekklésia:

$$
{ }^{1} \text { Congar, p. 23. } \quad{ }_{1} \text { Pet } 2: 9 . \quad{ }^{3} \text { Gen } 12: 1-3 \text {. }
$$

${ }^{4}$ Johannes Blauw, The Missionary Nature of the Church (Grand Rapids: William B. Eerdmans Publishing Company, 1974), p. 22.

${ }^{5}$ Exod 19:4. $\quad{ }^{6}$ Blauw, p. 28. 
The very usage of ekklēsia is suggestive of Paul's concept of the church. . . Ekklesia is never used of a building as is the English word 'church.' It is the assembly of the saints for worship. As such ekklessia can designate the believers who gather in a particular home as a house church (Rom 16:5;

Col $4: 15)$. It can designate the totality of believers living in one place--Laodicea (Co1 4:16), Galatia (Ga1 1:2). . . The church universal is not thought of as the totality of all the local churches; rather, each community however small, represesents the total community, the Church.

Thus as the human community responds to the "summons" or "call" (ekkleoo) of God it becomes "at one and the same time the community of the redeemed and the redeeming community. ${ }^{2}$

The priesthood of believers

In his first epistle Peter applies another old Testament image to the Christian community, namely, the "priesthood of all believers." "You are a chosen race, a royal priesthood, a holy nation, a people for God's own possession, that you may proclaim the excellencies of Him who has called you out of darkness into His marvelous light. ${ }^{3}$

This concept was introduced by God Himself at Mount Sinai when, after delivering the Israelites from Egyptian bondage, He condescended to enter into a covenant relationship with them: "And yet shall be unto me a kingdom of priests, and an holy nation. These are the words which thou shalt speak unto the children of Israel. 14

${ }^{1}$ Claud Welch, The Reality of the Church (New York: Charles Scribner's Sors, 1958), pp. 46-48.

2 Peter Beyerhaus and Henry Lefever, The Responsible Church and the Foreign Mission (Grand Rapids: William B. Eerdmans Publishing Company, 1964), p. 110 .

$$
31 \text { Pet } 2: 9 \text { (NASB). } \quad{ }^{4} \text { Exod 19:6. }
$$


God's origina1 plan for Israel was for them to be a "kingdom of priests." 1 This means that God's intended purpose in the establishing of the theocracy was for every Israelite to be a priest, everyone a king morally and spiritually. Priests in that they were "to draw near to God in prayer, in praise, and sacrifice." Priests also in the sense that they were privileged to act as "intermediaries between God and the heathen." 2 They were to represent God and the way of holiness to the heathen, and as prophets and preachers were to instruct them in the plan of salvation.

After Israel's failure to recognize in Jesus of Nazareth the promised Messiah, God, observes Peter, granted those privileges to the Christian Church as the new Israel of God, adding the significant term "royal" to priesthood. As God's special possession and children of the King of kings they are "royal." 3 As priests they are to offer up spiritual sacrifices unto God, acceptable to God through Jesus Christ and have "the right to approach God directly." 4 No one is to speak to God for them, nor come between them and God.

The picture which then emerges is obvious: Christ is the on1y "Great High Priest" and His people are priests on whom He confers the privilege of coming "boldly to the throne of grace." 6

${ }^{1}$ Francis D. Nichol, ed., Seventh-day Adventist Bible Commentary, 7 vols. (Washington, D.C.: Review and Herald Pub. Assn., 1955), 7:261-62 (hereafter cited as SDA Bible Commentary).

2 Ibid., 1:595.

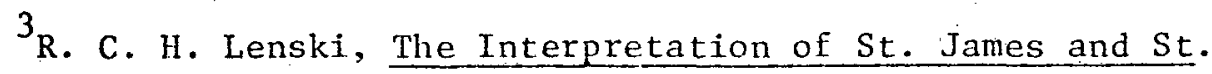
Peter (Columbus, Ohio: Wartburg Press, 1945), pp. 101-2.
${ }^{4}$ Ibid.
${ }^{5} \mathrm{Heb} \quad 4: 14$.
${ }^{6}$ Heb 4:16. 
Christ, then, is the one great High Priest and His followers are the new priesthood. This was the conviction that prevailed in early Christianity:

It was a striking characteristic of early Christianity that it had no offering, and therefore, no priest. All the faithful were conceived as priests and prayer as their offering. But if a11 were priests there was no room for a professional priesthood. . . . This idea of a congregation of priests (universal priesthood) was a favorite in the ancient church and was regarded as part of the superiority of Christianity. 1

The ministry of the laity

Various evidences substantiate the fact that the ministry of the early church was predominantly a ministry of the laity--the laos. There was definitely no clerical order in the early church. "The old Testament distinction between priest and people, clergymen and layman, is at an end. Christ, our High Priest, has made all Christians priests unto God. All Christians are God's clergy." ${ }^{2}$ Certainly the apostles gave order and direction to the Early Church, but the type of organization that existed facilitated and enhanced the ministry of the believers:

The external organization and administration of the early church was such as befitted the royal priesthood of God's children. In that community of brethren all were of equal dignity. Each member had for himself access to the Word and heart of God, and to all co-jointly had been given one office, the ministry of the Word. 3

${ }^{1}$ Samuel Macauley Jackson, ed., The New Schaff-Herzog Encyclopedia of Religious Knowledge, 12 vols. (New York: Funk and Wagnalls Company, 1911), 9:251-52.

2 Mark A. Noll, "Believer-priests in the Church: Luther's View," Christianity Today, October 26, 1973, pp. 4-8.

${ }^{3} \mathrm{C}$. Abbetmeyer, Four Hundred Years (St. Louis: Concordia Publishing House, 1917), p. 3 . 
The ministry, then, was to be considered as an office and not as an order, and the church should be a government of God through the people and for the people, and all Christians are the people. 1

The word "ministry" is a loose translation of the Greek diakonia (already noted) which means service or stewardship. ${ }^{2}$ This was doubtless the basic law for the life of the Christians of the early congregation: "You must serve one another, each with the talent (charisma) he has received as efficient stewards (in oikonomoi) of God's varied grace." ${ }^{3}$ Hence all New Testament Christians were diakonoi, ministers, called to a ministry. "In the primitive church every activity or function which contributed to the upbuilding of the Christian community was brought under the category of diakonia. "4

And he gave some to be apostles, and some to be prophets, and some to be evangelj.sts, some to be shepherds, and some to be teachers, for the equipment of the saints, for the work of the diakonia, for the upbuilding of the body of Christ. 5

This emphasis on diakonia the people of God inherited from the Lord Jesus Himself Who "came not to be ministered unto but to minister and to give his life a ransom for many." 6 . "Al1 the stress was on the diakonia, the ministry of the whole membership because the church as a whole stood under the same token as the Lord, i.e.,

${ }^{1}$ Oscar E. Feucht, Everyone a Minister (St. Louis, Concordia Publishing House, 1974), p. 35.

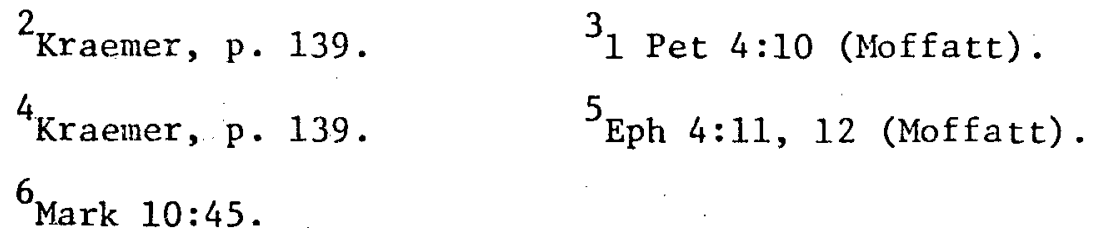


'servantship."'1 As the chief of servants ${ }^{2}$ Jesus calls His disciples $^{3}$ to "ministry," that is to say, service both for God and his fellowmen:

He himself is the Servant par excellence and He calls us to be servants too. This much then is certain: if we are christians we must spend our lives in the service of God and man. The only difference between us lies in the nature of the service we are called to render. Some are called to be missionaries, evangelists or pastors; others to great professions of law, education, medicine and the social sciences; ${ }_{4}$ but others are called to commerce, industry, farming. . .

It is for the effectiveness of this ministry of the laity. that we find spiritual gifts bestowed on the Church. Paul develops this theme in three principal passages ${ }^{5}$ with the intent that there should be no misunderstanding relative to spiritual gifts (charismata) and the minstry. 6 "These gifts are the consequence of the presence of the 'Spirit of promise' who indwells all believers. . . They are given by our Lord for the purpose of equipping His people for the work of the ministry." Hence the gifts are the manifestation of the Spirit through the believer to make his service effective. ${ }^{8}$

If we accept this New Testament concept of the whole church

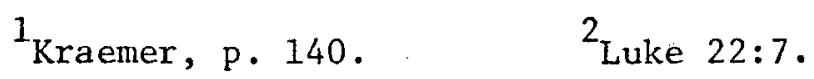

3 Matt $20: 25-28$.

${ }^{4}$ John R. W. Stott, Christian Mission in the Modern World (Illinois: InterVarsity Press, 1.975), p. 31.

${ }^{5}$ Rom 12:3-8; 1 Cor 12-14; Eph 4:14-16.

6"It is important, brethren, that you should have clear knowledge on the subject of spiritual gifts" 1 Cor 12:1 (Weymouth).

7 Lewis A. Drummond, Leading Your Church in Evangelism (Nashville: Broadman Press, 1975), p. 70 .

${ }^{8}$ Ibid. 
as ministry, diakonia, it becomes evident that the laity living in the world is the primary body through which the ministry has to be manifested in a11 spheres of 1 ife. $^{1}$ Furthermore, and in the words of Kraemer, it means that "the Church, being ministry, being diakonia in correlation to Christ's diakonia or ministry" is under divine obligation to show in "her own life signs and evidences of this divine order which is in Christ an operative fact." 2

The role of the pastor

If the ministry of the church is indeed and in truth the laity the question naturally arises, what then is the role of the pastor? The answer is given by Paul in Ephesians 4: "He ascended into the heights with captives in His train, He gave gifts to men -. some pastors and teachers 'to equip God's people for work in His service to the building up of the body of Christ. " 3

The purpose of the pastors and teachers and evangelists in their gift and calling is to equip the ministers (laity) for their ministries. ${ }^{4}$ Pastors and Christian teachers are supplied to the laos by the Spirit for the express purpose of preparing the whole church for service according to the individual gifts of the members. In the authoritative writings of the Church this matter of the church being a training center for service (diakonia) has been repeatedly emphasized:

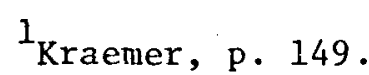
2 Ibid.

$3_{\text {Eph } 4: 7,8 \text { (NEB) }}$.

4 David Haney, The Idea of the Laity (Grand Rapids: Zondervan Publishing House, 1973), p. 40 . 
Every church should be a training school for Christian workers. - . An education should be given that would result in furnishing hundreds who would put out to the exchanges valuable talents. By the use of these talents, men would be developed who would be prepared to fill positions of trust and influence, and to maintain pure, uncorrupted principles.

There should be well organized plans for the employment of workers to go into all our churches, large and small, to instruct the members how to labor for the upbuilding of the church, and also for unbelievers. It is training, education, that is needed. 1

\section{Purpose of the Church}

The purpose of the church is not only to extend the kingdom of God in the world by proclamation but to prepare men and women for the kingdom of glory. This is God's plan and purpose for the existence of the church from its inception. Therefore, the church must demonstrate (by koinonia) the kingdom of God. "The church exists to demonstrate the kingdom of God and then to spread it." ${ }^{2}$ This is our obligation to Christ and our debt to the world. The church is the theater of His grace. 3

To this end, therefore, the church exists and not primarily for itself. ${ }^{4}$ God's plan has ever been to save the world (oikoumene) i.e., mankind from eternal destruction, ever since the entrance of sin. But this plan of salvation is made operative through the church to which He has entrusted the revelation of this plan for the world.

${ }^{1}$ Ellen G. White, Christian Service (Washington, D.C.: Review and Herald Pub. Assn., 1947), pp. 58, 59.

2 Haney, p. 36.

3 Ellen $G$. White, Acts of the Apostles (Mountain View, Calif.: Pacific Press Publishing Assn., 1948), p. 12.

${ }^{4}$ Kraemer, p. 127. 
In justice to the whole account of the history of God's selfdisclosure, aiming at the salvation and redemption of the world, it must be stated as at first point that God is concerned about the world. In all that has happend in Christ the whole of mankind is in God's view. The Church is provisional, not definitive. 1

The Church, therefore, holds her mandate from her Lord ${ }^{2}$ who set the example by His divine self-disclosure on behalf of the

Father: "As thou hast sent me into the world even so have I also sent them into the world." ${ }^{3}$ The supreme task of the church, then is to declare the wonderful deeds of God "who has called you out of darkness into his marvelous light." ${ }^{4}$ This implies an evangelistic responsibility hinged on the theology of mission. 5

\section{Missio Dei}

This purpose of the church should not only hold priority in her program but should be recognized as the ground of her very being; thiat is to say, the Church herself is mission:

In no way can mission be viewed as one among other tasks to which the church is called. A church that knows that she is a function of the apostolate and that her very ground of existence lies in the proclamation of the kingdom to the world does not engage in missions, but she herself becomes mission, she becomes the living outreach of God to the world. 6

As the church assumes this grave responsibility of mission proclaiming who Jesus is and the saving power of God through Him; "the He is

${ }^{1}$ Ibid.

3 John $17: 18$.

${ }^{5}$. Pierce Beaver, The Missionary Between the Times (New
2Matt 29:19, 20 .

${ }^{4} 1$ Pet $2: 9$.

York: Doubleday \& Company, 1968), pp. 8-13.

${ }^{6}$ Hoekendijk, p. 43 . 
Savior, Reconciler, Lord; the Way, the Truth and the Life; the good Shepherd, the great Physician, the Prince of Peace"1 whom to know is life eternal, she has the unfailing assurance that "the mission (or apostolate) is Missio Dei ${ }^{2}$--it is the mission of her Lord. The work of salvation -is really not hers in terms of origin or ownership; it is the Lord's (ergon Theou). ${ }^{3}$. It originated with Him, but He works through the church to accomplish His mission: "The inner urge of God towards the world entered into the world in Jesus Christ and through the church this divine urge continues. The church is the community of the sent. . . She is sent to and into the world." 4

The symbol of the kingdom

It is in this sense of total identity with God's interest in the world that the church is also a symbol or agent of God's saving grace. W. O. Carver observes:

The church is the core of God's kingdom as being realized in human history. Local churches are the agencies of that kingdom and of its gospel; thus they are colonies of the kingdom of heaven on earth located in the midst of the world which is to be won through the gospel. 5

As agents or representatives of the kingdom (Paul uses the term "ambassadors") the people of God should consider their 1ocal churches as "immigration centers for heaven" 6 and themselves as recruiting

${ }^{1}$ Beaver, p. 10 .

$3_{\text {Hoekendijk, p. } 42 .}$

5 W. O. Garver, What is the Church? (Nashville: Broadman
2 Ibid.

${ }^{4}$ Kraemer, p. 133.

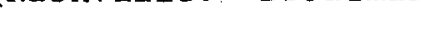
Press, 1958), p. 13 .

$$
\text { 6 Haney, p! } 30 \text {. }
$$


agents and training instruments. This makes it even more obligatory

for the church to be "on permanent display" before the world, "exhibiting the workability of the kingdom idea; that in Christ there is no division" ${ }^{1}$ or dissension, but love and harmony.

This harmony is best seen in koinonia, the most tangible evidence of a genuine, godlike, reconciling live relationship which, in fact, is the ultimate reality of the church:

In her ultimate reality the Church is men's fellowship with God and with one another in Christ. She is also the totality of the means to this fellowship. From this fellowship aspect, her ultimate reality, the Church is the aggregate of those who are in Christ Jesus. This aggregate is quite a different thing from a simple juxtaposition of individuals in a group: it is a people, the people of God. ${ }^{2}$

The church an implement of salvation

This ultimate reality in the final analysis, is in essence the jmplementation of the plan of salvation--to restore the broken relationship caused by sin. Sin alienates. It disrupts basic relationships. ${ }^{3}$ Sin means a refusal by mail to let God act in his life. This means rebellion against God. Thus before Go, man "stands condemned. Judgment--eternal judgment--is his lot, for the essential God-man relationship is corrupted. "4

This corrupted God-man relationship affects not only society by broken homes, family estrangement, ${ }^{5}$ race hatred, national disturbances and international tensions and frictions but more subtly, and

$1_{\text {Jbid. }}$

3 Drummond, p. 39 .

5rie Bronfenbrenner, "Nobody Home: The Erosion of the American Family," Psychology Today, 10 (May 1977): 41-43. 
worst of all, the individual's own self-relatedness is corrupted:

"Sin in relation to one's own relatedness is corrupted by evil just as surely as are the other essential relationships of 1 ife." ${ }^{1}$ The individual experiences internal derangement, perversion, frustration and depression; and only as he comes to himself, like the prodigal, and becomes properly related to God can he properly relate to others and to himself. ${ }^{2}$

The restoration of relationship, then, is part of the core of the gospel. ${ }^{3}$ In this sense a theology of relationship becomes vital to the church (the laos). 4 The Church is a stage before the world in which God demonstrates the power of His love to effect this miracle of koinonia in the healing of relationships. Hence the responsibility of the people of God to the world of aliens, "since the apostolate and the laity belong essentially together. " 5 This is a most urgent task of the church:

As long as it is day the community of Christ may and must proclaim the deeds of God, and therewith, in her turn, call men out of darkness into 1ight; out of alienation into true fellowship with God and man; out of a twilight situation of mercilessness into the joy of mercy. 6

In this responsibility, however, the pastors have an equal share, inasmuch as it is their duty to "equip the laity" for service. This necessitates an ongoing Christian education. In equipping and preparing God's people for this evangelistic imperative it is the

${ }^{1}$ Drummond, p. 39 .

2 Ibid.

3 Leslie, p. 122 .

${ }^{4}$ This will be given full treatment in the following section.

${ }^{5}$ Hoekendijk, p. 87. $\quad 6_{\text {Blauw, p. } 135 .}$ 
pastor's responsibility to see that every available resource for training the ministry is utilized for total mobilization. ${ }^{1}$ To be successful in such a training program it is imperative that one recognizes certain structural elements as essential. The words of Christ in Mark's gospel provide a good base for this structure. ${ }^{2}$ Three goals should be specified as general guidelines for optimum results:

(1) To grow in relation to God;

(2) To develop trustful and responsible relations with others and help them gain a similar relationship with God;

(3) To become a whole person (personal relatedness)..$^{3}$

These three principles accentuate the need for a proper understanding of the theology of relationship among the laity and, therefore, should be a definite part of the continuing education and training of the laos. Failing this "few Christians will ever become equipped to engage successfully in outreach. " 4

${ }^{1}$ In urging the church to take advantage of the recent findings of behavioral scientists' research to enhance the effectiveness of the ministry of the church, Shutz and Rekers emphasize: "We are not advocating a substitution of social-psychological-motivational techniques for the Holy Spirit's work in the believer's life. Instead we recognize that each individual Christian must draw upon God's indwelling power to accomplish the work of the body of Christ. Once empowered by the Spirit the Christian might be confronted by an efficient or an irefficient church organization in which to work. We are advocating the use of social-scientific research methods to enhance the interpersonal relationships which make up the church structure, and programing that is geared to the mobilization of the laity for the task of evangelism." Samuel R. Shutz and George A. Rekers, "A Proposal for Lay Mobilization in Evangelism Utilizing Behavioral Technology," Journal of Psychology and Theology 1 (July 1973): 43.

${ }^{2}$ Mark 12:28-31. ${ }^{3}$ Drummond, p. 64 .

${ }^{4}$ Ibid. 
Toward a Theology of Relationship

Undergirding the biblical foundation of the laos as the people of God is the koinonia concept already referred to and which really lies at the heart of the concept of Christian fellowship. This implies a certain quality relationship between God and His people (the 1aos) on the one hand and on the other, within the laos or among His people as well. The Church in its ultimate reality is a fellowship of persons..$^{1}$ It is this special kind of relationship that creates the climate for mutual member-to-member ministry within the laos and constrains the members to labor for others outside the laos. "The love of Christ constraineth us." 2

This matter of relationship is the focal point in the plan of redemption and is central to the gospel of Christ. Jesus. Leslie observes that "unless persons can have meaningful feeling-level relationships, they cannot begin to appreciate Jesus or His :Leachings." ${ }^{3}$ It is from his perspective that Robert Dow and others term this concept "the theology of relationship." 4 Stated simply: this theology of relationship "suggests that the primary biblical injunction is to relate in love to God, to self and to others as the ultimate and authenticating mark of life in Christ." 5

This relationship encompasses not only man's relationship to

${ }^{1}$ Congar, p. 22. 2 Cor $5: 14$.

3 Leslie, p. 122 .

${ }^{4}$ Robert Arthur Dow, Learning Through Encounter (Va1ley Forge: Judson Press, 1971), p. 52.

5 Bruce Larson, "What Makes Theology Relationa1?" Faith at Work, June 1977 , p. 5. 
the rest of creation (the doctrine of man's creation, fall and reconciliation ${ }^{1}$ as well as man's relationship with man) but man's relationship to God. This is summarily expressed within the context of the Judeo-Christian tradition in three monosyllables, "God is love." 2 This seems to be the central theme of the Johanine writings. 3 . Contrary to the Gnostic's ${ }^{4}$ idealization of 1 ife derived from Greek philosophy which conceptualized God as an idea ${ }^{5}$ John emphasizes the reality of a living, personal God in terms of the most vital and meaningful relationship, "God is love." This involves koinonia. "God is not a geographic or national hex. He is not an idea. He is relationship. Love and relationship are interchangeable in this sense, for love is a relationship and there is no real relationship without love." 7

This love relationship is rooted in the divine affinity of

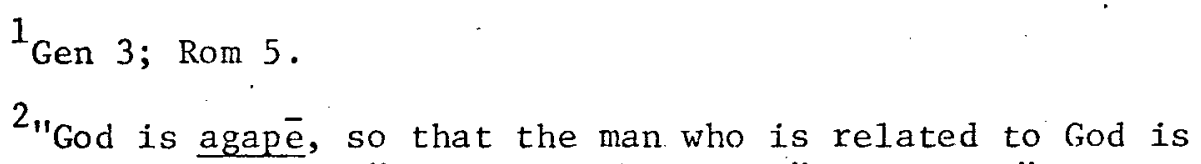

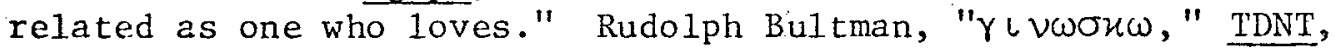
$1: 711$.

3 Albert Barnes, Barnes on the New Testament, 20 vols. (Grand Rapids: Baker Book house, 1953): 19:330.

4"Docetist from the Greek meaning 'to seem.' The Doctic Christology held that the Christ was only 'seemed' to be man; His reality was actually the spiritual, that is, non-material, being of God." Donald G. Dawe, "The Humanity of Christ and the Future of Man," Affirmation 1 (September 1973): 8.

${ }^{5}$ Dowe, p. 52 .

6 Like ginōskein, agapē determines the relationship between the Father and the Son (John 3:35) and also between Jesus and His own (John 13:1, 34). Bultman, 1:711.

$$
7_{\text {Dow, p. }} 52 \text {. }
$$


Father and Son and in turn, is extended to the human family:

Apart from its ordinary use the word (ginōskein) here denotes emphatically relationship to God and to Jesus as a personal fellowship. . . . As the relationship between Father and Son - . is mutual ginoskein, so is the relationship between Jesus and His own (John 10:14-27). Thus it is obvious that ginoskein is the supreme and true mode of being; but it is also obvious that materially this is understood to be agape (love). ${ }^{1}$

Seen in this light, this love relationship between Father and Son has far reaching implications for the world of intelligent beings. This is clearly reflected in John 3:16: "For God so loved the world that He gave His only begotten Son. . . ."

This relationship also supplies the model from which all human life seek meaningful existence.

Humanity's need for this relationship

A Christian life lived in this love relationship is immediacely bolstered and sustained by two powerful affirmations that are in themselves essential for growth and development in selfactualization: a sense of belonging ..."I belong"--and a sense of self-identity. ${ }^{2}$ This love relationship also becomes focal in our understanding of reconciliation in God's overall plan of redemption and in this sense has soteriological implications, for the plan of salvation involves the restoration of a genuine relationship between man and his Creator on the one hand, as well as between man and his fellowman on the other.

The apostle John epitomizes this theology of relationship by

$1_{\text {Bultman, p. } 711 .}$

2Dow, p. 50 . 
declaring: "Beloved, if God so loved us we ought to love one another,"1 and Jesus emphasizes: "A new commandment I give unto you that ye love one another; as I have loved you that ye also love one another." 2 Christ does not only require this love relationship among His followers but He supplies the power to live it out:

The Christ who makes human love for God and neighbor possible by His demonstration of the greatness of God's love for man... is also the One who requires what He has made possible. : . . No one can be a member of the Christian fellowship who does not acknowledge Jesus as the Christ and the Son of God and who does not love the brothers in obedience to the Lord. ${ }^{3}$

In the light of such a manifestation of God's love "there can be no question about the obligation to mutual love among those who experience it." 4

Koinonia distinguishes the Christian community

This fellowship is definitely a Christian concept that is grounded in the love of God manifested through Christ for His people. ${ }^{5}$ It at once becomes the essence of the binding force of the

$1_{1}$ John $4: 11$. $\quad{ }^{2}$ John $13: 34$.

$3_{H}$. Richard Niebuhr, Christ and Culture (New York: Harper and Row Publishers, 1974), pp. 46-47.

${ }^{4}$ A. E. Brooks, A Critical and Exegetical Commentary on the Johanine Epistles, International Critical Commentary (Edinburgh: T. \& T. Clark, 1957), p. 119.

5 "Koinonia refers to the community or fellowship that emerges and exists in response to the love of God in Jesus Christ, which expresses in limited ways the communion or fellowship that God has for His children." Thomas C. Oden, The Intensive Group Experience (Philadelphia: Westminster Press, 1952), p. 91. 
Christian community. This was ideally exemplified by the New Testament church. ${ }^{1}$

The genuine love relationship exemplified in the laos of the New Testament is still the ideal for the laos today. ${ }^{2}$ It has not changed; indeed it cannot be changed since its very character is rooted in the Father-Son relationship and in our Lord's Incarnation. Bonhoeffer describes this love as follows:

Spiritual love is bound solely to the word of Jesus Christ. Where Christ bids me to maintain fellowship for the sake of love I will maintain it. . . Because spiritual love does not desire but rather serves, it loves an enemy as a brother. It origininates neither in the brother nor in the enemy but in Jesus and His word. 3

It is this unique love relationship that accounts for the essential differnece between the Christ-centered fellowship group and other fellowship groups that are only socially oriented, ${ }^{4}$ or other sensitivity groups that are solely psychologically oriented. This spiritual centripetal force draws people to Christ, the center, the Source from which this force emanates; and the closer people come in relationship to Christ as they move toward the center, the closer they come to one another in a deepened interpersonal relationship. This relationship, then, that is grounded in koinonia constitute the very essence of the laos, hence ekklessia is not conceived of

$1_{\text {Ed Barlow, Small Group Ministry in the Contemporary Church }}$ (Missouri: Herald Publishing House, 1972), p. 22.

2 John $1: 7$.

3 Dietrich Bonhoeffer, Life Together, trans. John W. Dober-stein (New York: Harper and Row, 1954), p. 35.

${ }^{4}$ Congar emphasizes that from the point of view of the church's sociological structure this fellowship "radically distinguishes her from every society that is purely earthly or human." p. 24 . 
as an institution, but rather as a fellowship of persons. To be in Christ through faith and to be in this fellowship are one and the same thing. ${ }^{1}$ This quality fellowship was demonstrated by the Lord Jesus throughout His ministry. Irving Harris emphasizes the centra1ity of His work in association "with a few close friends" (disciples)..$^{2}$

The first concern of these disciples was to maintain an enlarge the fellowship (koinonia) they began with their Master. ${ }^{3}$ This fellowship was an experience of living together. The members cared for one another and bore one another's burden. 4 They shared their possessions. ${ }^{5}$ They communicated openly and honestly with one another ${ }^{6}$ and they trusted one another. "Those who belonged to this fellowship," comments Philip Anderson, "were one with one another and with God; they were reconcijed to one another and to God." 7

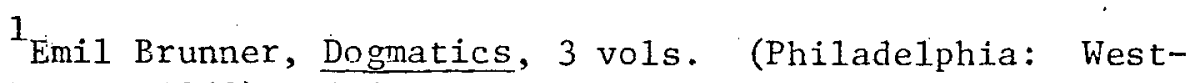
minster Press, 1962): $3: 21,22$.

2 Irving Harris, "Finding a Handle," Groups That Work (Grand Rapids: Zondervan Publishing House, 1968), p. 12.

3 Philip Anderson, Church Meetings That Matter (Philadelphia: United Church Press, 1965), p. 21 .

${ }^{4}$ Bear ye one another's burden and so fulfill the law of Christ. Gal 6:2.

${ }^{5}$ And all that believed were together and had all things common - . and parted them to all men as every man had need. Acts $2: 44,45$.

${ }^{6}$ But speaking the truth in love may grow up into him in all things which is the head even Christ. Eph $4: 15$.

7 Anderson, p. 21 . 


\section{Importance of Christian Community}

for Individual Growth

The concept of laos as a redeeming community as we11 as "the community of the redeemed" ${ }^{1}$ creates the picture of a Christian church with an upreaching hand holding to the divine love relationship for continuous sustenance, on the one side and on the other, reaching out the hand of ministry to the surrounding world.

There seems to be a special design in God's plan of salvation that while people are individually saved by a personal relationship with Christ, salvation is effected to quite an extent within the context of the Christian community. ${ }^{2}$ To state it differently, while salvation involves the restoration of persons to the divine fellowship it also involves the establishment of a unique relationship with the community of those who are saved.

Trueblood declares that this is why "there cannot be any vital christianity without an increased sense of being members of one ancther." ${ }^{3}$ It is true that groups may fail, but it is also true that there is less power without them. "Neither I nor any one else can be a Christian alone." ${ }^{4}$ It is God's will that we should find His living word in the witness of our brethren. A Christian, therefore, needs another Christian who will speak God's word to him. He needs him in times of discouragement and uncertainty. "He needs his brother man as a bearer and proclaimer of the divine word of

$1_{\text {Beyerhaus and Lefever, p. } 110 .}$

${ }^{2}$ Oden, p. 109.

${ }^{3}$ D. Elton Trueblood, Introduction to Groups That Work, p. 7. ${ }^{4}$ Ibid. 
salvation. He needs his brother solely because of Jesus Christ." 1

\section{Community Contributions Through Sma11 Groups}

What are some of the specific contributions that the Christian community can make toward the development of the individual's Christian experience in the context of koinonia and diakonia?

\section{Self-discovery}

Because of the human tendency to project the "should be" inage among our associates we tend to create a false picture of self-identity and thus fail to give recognition to the real self which may be "boxed in" by feelings of resentment, hostility, and loneliness, almost to the point of desperation. The result is that we have a ready reservoir of hostility and too little reserve of joy. The conscious life becomes narrowed as the inner defense system becomes thickened, i.e., we become "more closed." Relationships become functional, that is, we use each other. They are seldom interpersonal, that is, "where we enjoy each other." 2

It is only within the context of the group experience (through feedback) that genuine self-perception ${ }^{3}$ can be acquired, and by the support of the group this illusion ${ }^{4}$ can be smashed through to the authentic self where we see ourselves as others see us.

$1_{\text {Bonhoeffer; p. 23. }}$ 2 Dow, p. 63.

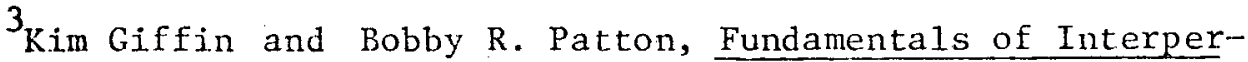
sona1 Communication (New York: Harper and Row, Publishers, 1971), p. 73 .

${ }^{4}$ Dow, p. 63 
Self-acceptance

It is said that one of the hardest doctrines of the Christian faith to receive is self-acceptance, not because of what a man does but "because of who he is." 1 There is the common tendency, as we have seen, in an effort to be acceptable (or project one's selfimage) an individual tends to withhold anything of himself that is unpleasant, undesirable or unattractive. "But the small group provides opportunity within the supportive trust that gradually builds up, to risk sharing even the dark aspects of one's 1ife." 2

Incarnate love

In the warm climate of a small sharing group provided by the community $^{3}$ the individual can feel free to abandon this facade of predetermined inage (identity) and without fear or embarrassment follow the example of our Lord and Master ${ }^{4}$ in risking an "encounter in the real world where we must fashion a new identity in relation with others." $"$.ike our great Exemplar "to incarnate love we have to risk an openness that exposes us to everyone. Our inner defences must be diminished." 6 In this atmosphere of openness and honesty within the group context trust and acceptance soon develop to a

$$
1_{\text {Leslie, p. } 101 .} \quad{ }^{2} \text { Ibid. }
$$

3 "Here a theology of relationship is absolutely essential to a community of fellow believers who want to be supported of another pilgrim's struggle to leave his addictive behaviors and reach for love's eternal intimacy." Dow, p. 63.

${ }^{4}$ Let your bearing toward one another arise out of your life in Christ Jesus. For the divine nature was His from the first; yet He did not think to snatch at equality with God, but made Himself nothing assuming the nature of a slave. (Phil 2:5-7, NEB)

$$
{ }^{5} \text { Dow, p. } 63 \text {. } \quad{ }^{6} \text { Leslie, p. } 93 .
$$


significant level. Thus "love becomes incarnated in individual personal relationships." 1

Healing

Like the "dead flesh" of an old wound which cannot be healed until it is "cleaned out" so spiritual healing cannot take place in the soul until the "dead flesh" of repressed feelings of resentment, hostility or any other negative feelings be "cleaned out" by confession--openness, honesty, and transparency. 2 "There is no substitute for being honest about yourself," says Bruce Larson. He feels that in the small group it is easier for people to come out with their real problems "and Bible truth instead of being presented theoretically is revealed in action and meets them at their point of need where God's love focusses." ${ }^{3}$. This concept is well endorsed in the following excerpt from Clemmons and Hester:

- . The dealing with self-awareness in a sharing group becomes an experience of God's grace administered to us. . . . It is through another that both the awareness of the blockages occurs and the healing takes place. . . the healing power of Christ is administered through others--this is part of the humility of Christian community that I must learn-I can't $t_{4}$ heal myself. - . We are all made and healed in community.

Madden goes even further as he makes this challenge to authenticity and acceptance of the "self" and a willingness to

${ }^{1}$ Leslie, p. 93.

2 Bruce Larson, "Honesty is the Only Policy," in Groups That Work (Grand Rapids: Zondervan Publishing House, 1968), pp. 21, 22 .

${ }^{3}$ Ibid.

${ }^{4}$ William Clemmons and Harvey Hester, Growth Through Groups (Tennessee: Broadman Press, 1974), p. 73. 
accept the affirmation of others crucial to the healing experience:

Whoever brings acceptance in a total way brings healing. Whoever cannot accept affirmation from others cannot be healed. Whoever shuts himself off from sharing his deeper self imposes on himself a kind of isolation or banishment. . . A genuine self-acceptance must be started at some point outside the self. It must come from another self who has been able to turn to accept healing from his own brokenness. 1

\section{Wholeness}

Another vital contribution of the community through small sharing groups is the development of the sense of "wholeness" by the individual. Leslie defines wholness as salvation, " 2 a restoring of fundamental unity." This implies both a "sense of inner integration and an external relatedness both to fellowmen and to God." 3

In the interest of accelerating the process toward this goal--"the ideal of personal relatedness"--the sharing of feelings in the small group is as important as the sharing of mere ideas. 4 This coincides with Oden's view that salvation is mediated interpersonally and not through a professional elite but through a community of ordinary people. "It is mediated, not through jdeas but through relationships that enable persons to overcome that demonic power of

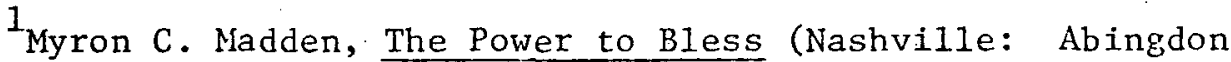
Press, 1971), p. 141 . (p. 108).

2 Salvation, for Oden, means health from the, Latin, salvus

3 Leslie, p. 108 .

4 "The more hearing of sermons Sabbath after Sabbath, the reading of the Bible through and through, or the explanation of it verse by verse will not benefit us or those who hear us unless we bring the truths of the Bible into our individual experience." White, Ministry of Healing, p. 514. 
anxiety and guilt." 1 People are changed not by mere cognitive knowledge of their predicament but by entering into a new relationship in which they are assured that they are positively valued by others. 2

\section{Intercessory prayer}

The role of intercessory prayer in enhancing the development of this goal of ideal "personal relatedness" should also be emphasized:

The concern that manifests itself in intercessory prayer prepares the way for a meaningful relationship between people. . . . Knowing God not only helps us to know people but knowing people helps us to know God. The relationship of rapport is the highway by which the Spirit of God communicates His word. . . . Without the communion of saints, communion with God could generate into a monologue with oneself. 3

Bonhoeffer gives equal prominence to this vital role of the mutual ministry of members' intercessory prayer in developing meaningful relationships. A Christian fellowship can only live and exist by the intercession of its members for one another; otherwise it collapses. It is very difficult, almost impossible, for an individual to hate or condemn one for whom he prays, no matter how much trouble the latter causes. "His face, that hitherto, may have been strange and intolerable to me is transformed, in intercession, into

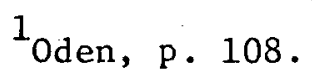

2 Ibid. Walden Howard adds: "We will find maturity only in a healthy interdependence on other Christians, through a fellowship where we can learn to be ourselves in an honest and loving relationship with others." "Barriers to Fellowship," in Groups That Work, p. 34 .

3 William Hulme, The Dynamics of Sanctification (Mineapolis: Augsburg Publishing House, 1966), p. 151. 
the countenance of a brother for whom Christ died, the face of a forgiven sinner." 1

It is by this mutuality of intercessory prayer that we truly.

learn to bear on another's burdens. ${ }^{2}$

\section{Growth}

It is the consensus among contemporary psychiatrists that growth and self-fulfillment cannot adequately be realized independently of the community. Hence the popular trend in psychiatry today is to deal with personal problems in the context of "family therapy and community psychiatry." ${ }^{3}$ Paul Tillich is credited with the statement: "No personal being exists without communal being. . . There is no person without an encounter with other persons. Persons can grow only in the communion of personal encounter." 4 ' It is, therefore, safe to say that growth as a human being means growth in personal relatedness. The small group which provides wide opportunties for enhancing personal relationship also leaves the door ajar to ever increasing areas of relatedness, even including the possiblity of a relatedness with the ultimate dimensions of 1 ife. ${ }^{5}$

$1_{\text {Bonhoeffer, p. } 86}$

2 Howard B. Haynes, "No Lonely Pilgrimage," in Groups That Work, p. 101.

3 Leslie, p. 97.

${ }^{4}$ Paul Tillich, Systematic Theology (Chicago: University of Chicago Press, 1951), p. 176.

${ }^{5}$ Leslie, p. 98 . 
Sense of mission

In the sharing-caring community there is developed a sense of concern for one another in the full realization that "I am my brother's keeper." "It is both the community that develops from commitment and the mission that grows out of caring." 1 As this sense of concern is developed in the sharing group attention is deflected from self-centered preoccupations to unselfish ministry for others and a genuine sense of mission." "Not only will small groups in the church assist persons in a deepening of their personal relationships with others, but they can become the means of restoring a sense of mission to the Church." ${ }^{3}$

\section{Fellowship of the Holy Spirit}

Finally, it must be observed that it is only in the context of the community that the "fellowship and communion of the Holy Spirit" can be fully realized. This view is shared by Ed Barlow. Iil contrast to his critical observation of contemporary church patterns and structures to provide "an informal atmo'sphere that allows freedom of the Spirit" he readily endorses one structure that does--certain forms of the small group: "It is my conviction that the koinonia of the Holy Spirit is most likely to be experienced where Christians meet together informally in such small group(s). . . . "4

${ }^{1}$ Dow, p. 123

2 Ed Barlow, Sma11 Group Ministry in the Contemporary Church (Missouri: Herald Publishing House, 1972), p. 19.

${ }^{3}$ Clemmons and Hester, p. 46.

${ }^{4}$ Barlow, p. 20. 
In summary it seems reasonable to conclude: (1) That the Creator who made man from one beginning ${ }^{1}$ knew long before the behavioral scientists that the influence exerted by group relationship has the greatest impact on the individual member for change. Note the following:

We are molded by our relationships. Only rarely do people make significant changes in their attitudes or actions entirely apart from some relationship. If in the church we are hopeful of changing persons (including ourselves) we should remember that it will most likely happen because of the relationships that are established or strengthened. . . We must continually examine our structures to see if they allow relationships to develop. 2

(2) That God's love-relation becomes more meaningful to the individual as it is reflected through the group love-relationship to individuals' unreserved acceptance, trust and support, (3) That spiritual growth and development ${ }^{3}$ of the individual Christian experience is greatly enhanced by the "mulching" provided by the group relationship--confrontation, affirmation, identification, through depth-level interpersonal communication. ${ }^{4}$ Trueblood observes:

The world needed a saving faith and the formula was that such a faith comes by a particular kind of fellowship. Jesus was deeply concerned for the continuation of His redemptive work after the close of His earthly existence, and His chosen method was the formation of a redemptive society. He did not form any army,

1 "So God created man in his own image, in the image of God created he him; male and female created he them" (Gen 1:26). "Ointment and perfume rejoice the heart; so doth the sweetness of a man's friend by hearty counsel. . . Iron sharpeneth iron; so a man sharpeneth the countenance of his friend." Prov 27:9, 17.

2 Wegmeyer, p. 69.

3 Ellen G. White, Testimonies for the Church, 9 vols. (Mountain View, Calif.: Pacific Press Pub. Assn., 1948), 7:195.

${ }^{4}$ These terms will be discussed in greater detail in later sections of this paper. 
establish a headquarters or even write a book. A1l He did was to collect a few unpromising men, inspire them with the sense of His vocation and theirs, and build their lives into an intensive fellowship of affection, worship and work. 1

In short, this theology of relationship rightly understood and applied will not only attract more members to the church and hold them (thus reducing the drop-out rate) ${ }^{2}$ but will definitely prepare the way for pentecost. ${ }^{3}$

${ }^{1}$ E1ton Trueblood, A1ternative to Futility (New York: Harper and Brothers Publishers, 1948), p. 29.

2 "After individuals ahve been converted to the truth they need to be looked after. . . These newly converted ones need nursing-watchful attention, help and encouragement. . . There should be more fathers and mothers to take these babes in the truth to their hearts and to encourage them and pray for them that their faith be not confused." Ellen G. White, Evangelism (Washington, D.C.: Reviev and Herald Pub. Assn., 1946), pp. 352-53.

"Only where a small group of disciples is gathered in His name is He present with that peculiar power which He promised His followers. That is to say that existence of a small group of persons committed to Christ and bound together in a special Christian fellowship is a necessary condition for the coming of the Holy Spirit. Large groups can ordinarily be so blessed only when there exists within them such dedicated groups of disciples." Barlow, p. 29. 


\section{THE SMALL GROUP PHENOMENON--ITS CHALLENGES AND}

\section{POSSIBILITIES FOR THE CHURCH}

By all probabilities one of the greatest challenges ${ }^{1}$ facing the Seventh-day Adventist Church today, not only in the West Indies, but possibly as a religious denomination, is the mounting interest in the small group phenomenon ${ }^{2}$ as one of the most powerful means of effecting change ${ }^{3}$ in human behavior socially, intellectually and spiritually.

Other segments of society--education, business, government, politics, military ${ }^{4}$-have been quick to seize the opportunity offered by utilizing (and in some instances even exploiting ${ }^{5}$ ) this phenomenon.

${ }^{1}$ Speaking of small groups, Barlow says: "The challenge to the church is to understand the dynamics and utilize them for the advancement of the kingdom of $\operatorname{God}^{\prime \prime}(\mathrm{p} .82)$ ).

2 "We are in the midst of the explosion of interest in the use of the small group. It has tremendous potentiality for the renewal of the church. . . All church leaders . . . should examine the new insights on the subject with great seriousness." Clyde Reid, Groups Alive--Church Alive (New York: Harper and Row, Publishers, 1969), p. 17 .

${ }^{3}$ Joseph Luft, Group Processes (Palo Alto. Calif:: The Nationa1 Press, 1963), p. 3.

${ }^{4}$ Darwin Cartwright, Group Dynamics (New York: Harper and Row, Publishers, 1953), p. 3 .

5 "Prisoners of World War II and the Korean conflict found the enemy using group method tactics to change loyalties when other types of 'brainwashing' failed. Efforts to change the philosophy of prisoners failed in the lecture method and in the one-to-one 
of group dynamics to great advantage: "There is no denying the phenomenon of the growing use of small group methods as a vehicle of learning and growth experiences." 1 Cartwright adds: "Educators are coming to believe that they cannot carry out their responsibilities fully unless they understand better how the classroom functions as a social group. "2

Relative to the impact in the bussiness world Gerard Egan informs us that for years business leaders have been interested in smal1 group laboratories as a means of improving managerial skills, human relations acuity and productivity in their organization. ${ }^{3}$

The proliferation of this small group phenomenon since the mid 1930s has captured the attention of behavioral scientists and other disciplines and has resulted in a "great burst of empirical research in the field of group dynamics." 4

encounter. However, when small groups of prisoners were assembled and the atmosphere of the discussion was controlled by the leader, a much higher rate of success in changing political ideologies was reported." Barlow, p. 82 .

${ }^{1}$ Gerard Egan, Encounter: Group Processes for Interpersonal Growth (Belmont, Calif.: Brooks-Cole Publishing Company, 1970), p. 1 .

$$
\begin{aligned}
& { }^{2} \text { Cartwright, p. 3. } \\
& { }^{4} \text { "This research, p. } 1 . \\
& \text {. began to display quite clearly the }
\end{aligned}
$$
characteristics that are now associated with work in group dynamics." Cartwright, p. 3. Taylor mentions some of the influences responsible for the interest in the small group phenomenon. Chief of these are the academic development of various disciplines: first, the theoretical and empirical work of sociologists takes historical priority; next, the research and practical concern of business and military agencies (studies by Mayo and his associates at the Harvard Business School); then psychological research (Noreno's work in the sociometric technique for the study of interpersonal choices, etc.); Kurt Lewin and his associates showing the determination of individual behavior by the properties of group atmosphere. Dalmas. Taylor, Small Groups (Chicago: Markham Publishing Company, 1974), pp. 2-4. 
The emergence of this growing interest in, and the rapid increase in preoccupation with the small group is interpreted by most behavioral scientists as an expression of protest against the depersonalization of society and a reaction against an impersonal religion in the church. ${ }^{1}$ Presumably there are various societal factors responsible for creating an apparent social and spiritual vacuum which the small group movement is endeavoring to fill. ${ }^{2}$ These multifarious and complex factors, however, may be classified under one distinctive heading with three subtitles: Relationship--the missing dimension in the family; the missing dimension in society; the missing dimension in the church.

\section{Relationship}

The missing dimension in the family

An inescapable by-product of the ever increasing industrialization of this technological age coupled with the concomitant urbanization is the accelerated mobility of this twentieth century society in comparison to previous generation. The consequent demographic instability adversely affects personal relationships in a variety of ways: Family roots are tragically uprooted, family ties are severed and social relationships are sexiously disrupted (if not entirely destroyed). Ralph Neighbors refers to this prevailing con-

${ }^{1}$ Ibid.

2 James A. Peterson, "The Interface of Institutions and Group Process," in The Group as Agent of Change, ed. Alfred Jacobs and Wilford Spradlin (New York: Behavioral Publications, 1974), p. 5 . 
dition as a "fragmentation of society," 1 and Cartwright observes that many thoughtful people are alarmed by "the apparent weakening and disintegration of the family." ${ }^{2}$

The resultant social milieu created by this volume of urbanization is a mass of people devoid of any significant relationship:

It has become a commonplace commentary on society today to speak of the way that the individual has been cut off from the primary life our forefathers found in the family, the nighborhood, and the settled community. He finds himself submerged in the mass of people around him, but without any true, firsthand relationship to anyone. He begins to believe the sociologist who speaks of society becoming a 'dust heap of individuals without links to one another. 3

The nissing dimension in society.

Compounding the effects of the mammoth scale of urbanization and industrialization on the individual in the society are certain depersonalizing forces ${ }^{4}$ impinging on the consciousness through our sophisticated technology and automation. ${ }^{5}$ For example, the

increasing trend toward bureaucratization of more and more aspects of the nation's Iife.

Coupled with the pressure of urbanization is the impersonality fostered by institutions and organizations. For example, mammoth

$1_{\text {Ralph Neighbors and Cal Thomas, Target Group Evangelism }}$ (Nashville: Broadman Press, 1975), p. vii.

2 Cartwright, p. 3 .

3 John L. Casteel, Spiritual Renewal Through Personal Groups (New York: Association Press, 1958), pp. 23-24.

${ }^{4}$ Clemmons and Hester, p. 45.

5 "Our automated, complex society has created a growing state of impersonality, and the yearning for closer personal ties is one of the major themes of our times." Giffin and Patton, p. vii. 
departmental stores and other "big mergers" create such impersonal business system that the opportunity for personal relationships is drastically reduced if not entirely eliminated. ${ }^{1}$

Another negative force in this social milieu is the pressure to conformity, as opposed to individualism: "Urbanization and its attendant and concentration of population and bureaucratization of work has led to increased valuation of conformity and adaptation to group requirement." The system, therefore, is apt to deface individuality. 2

The total effect of these and other dehumanizing forces in society is to heighten the sense of alienation and deepen the feelings of detachment. ${ }^{3}$ This situation is aptly described in the following words:

Something profound has perverted modern society. Human relationships fall apart, love fades, people are not communicating, anxiety grows, time is flashing by and society is selfdestructive. . . Each person fights to maintain his sanity in an uncaring society. 4

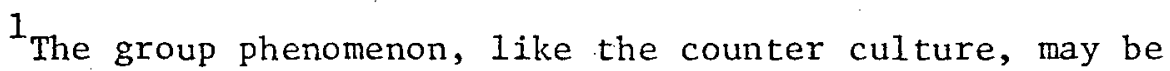
regarded as a protest against "Western Culture's artificial barriers that separates persons against its authoritarianism which nullifies individual freedom, and against its dehumanizing scientific and technological values." W. Michael Hoffman, "Ecology, Religion, and the Counterculture," Encounter 38 (Spring 1977): 100.

${ }^{2}$ Gerard V. Egan, "Group Insearch: Propaedeutic for a Contemporary Spirituality," Listening 12 (Spring 1977): 8.

3"The search for individual identity is implied in the following: 'The sole burden of poetry, theater, cinema, painting and fiction is that somewhere in there we lost ourselves and hence must grope pathetically for any straw of affirmation that may float by in the dark.' Tom Howard, "Who Am I? Who Am I?" Christianity Today July 8, 1977, p. 12 .

${ }^{4}$ Daniel J. Evearitt, "Paul Simon: The Only Living Boy in New York," Christianity Today, October 21, 1977,..pp. 21, 22. 
The upshot of all this is the subtle danger of losing a sense of the spiritual dimension of life. The life style characteristic of this modern technological society also militates against the "sense of soul." "The urbanization of society that seems to be a condition for industrialization, encourages a level of horizontal development that is inimical to the growth of the soul."1

Another subtle danger in the wake of this is the diminishing sense of self-esteem on the one hand and the increasing sense of loneliness on the other. The shallow, fleeting, manipulative "I-it" form of relating produces nothing to "replenish that most indispensable of inner resources, se]f-esteem." ${ }^{2}$ By the same token the massive cultural pressures increase a sense of loneliness and lovehunger and a need for an emotional point of reference or security.

Speaking to this point Trueblood states that there is a vast amount of loneliness and a consequent desire to belong to something. "Real fellowship is so rare and so precious that it is like dynamite in any human situation." ${ }^{3}$. This condition has been referred to as "a deep hunger" existing in modern society. Everywhere people are hungering for depth relationship. ${ }^{4}$ They need this relationship to give them a point of security and belonging in a world of such "rapid change and mass society. $"{ }^{5}$

${ }^{1}$ Egan, p. 8 .

${ }^{2}$ Howard J. Clinebel1, The People Dynamic: Changing Self and Society Through Growth Groups (New York: Harper and Row, Publishers, 1972, p. 13 .

3 Elton Trueblood, The Predicament of Modern Man (New York: Harper and Row, Publishers, 1944), p. 101.

$$
{ }^{4} \text { Reid, p. } 16 .
$$


The need for wholesome connection with "significant others" is emphasized by behavioral scientists who claim that it is quite possible to be more lonely in an airport or in a big sanctuary than in one's own room. They also claim that as good as solitude can sometimes be each human being requires some connection in which "loneliness is transcended by genuine sharing." 1 This enhances his best development. The fact is that technological man, despite his sophistication, is still a gregarious creature haunted by the herd instint, and needs this significant relation:

Man is by origin a herd animal. His actions are determined by a distinctive impulse to follow the leader and to have close contact with the other animals around him. Inasmuch as we are sheep there is no greater threat to our existence than to lose this contact with the herd and to be isolated. 2

This will to relate is the most powerful of human strivings. ${ }^{3}$ "One of our most compelling needs is to associate with others of our kind. Homospaiens are social creatures. Without comingling with other human beings they become lonely. "14

The missing dimension in the church

Unfortunately this missing dimension is also conspicuously

felt in our churches. It detracts from the quality of church worship and consequently exerts an adverse effect on church members. "Dogma,

${ }^{1}$ E1ton Trueblood, The Future of the Christian (New York:

Harper and Row, Publishers, 1971), p. 53.

${ }^{2}$ Eric Fromn, Psychoanalysis and Religion (New Haven, Conn.: Yale University. Press, 1950), p. 58.

${ }^{3}$ Clinebel1, p. 13 .

${ }^{4}$ Neely D. Gardener, Group Leadership (Washington, D.C.: National Training and Development Service Press, 1974), p. 4. 
denominatinalism and social respectability have largely overlaid the spirit of love in our churches."I It is observed that in a small intimate fellowship people's real problems have an opportunity to come into the open as opposed to the "cover-up" in the formal worship of the nominal congregation. "Bible truth, instead of being presented theoretica1ly, is revealed in action and meets men at their point of need where God's love always focusses. Human beings are very much alike." 2

The Seventh-day Adventist Church is by no means immune to this problem as has been attested to by Oosterwal's research: In the larger churches the "lack of fellowship" heads the 1ist (55\%) of reasons given for the believers' lack of spiritual commitment. ${ }^{3}$ It must be reiterated that when people were asked the question, "What aspect of your church do you feel could be improved?": 70 percent of them responded with, "More feliowship." 4

It is this intimate fellowship (koinonia) that made the New Testament community distinctive, and only this kind of fellowship can give that special quality to worship that assures certain satisfaction and meaningfulness to the worshippers today. 5

$$
\begin{array}{lc}
1_{\text {Harris, p. } 12 .} & \text { 2Ibid., p. } 13 . \\
3_{\text {Oosterwal, p. 30. }} & { }^{4} \text { Ibid., p. } 51 . \\
5_{\text {"A bar is possibly the best counterfeit there is to the }}
\end{array}
$$
fellowship Christ wants to give His church. It is an imitation, but it is like what the church ought to be, only with liquor at the center instead of grace--escape instead of reality. . .

"The bar flourished not because nost people are alcoholics, but because God has put into the human heart the desire to know and be known, to love and be loved. The church rarely offers this, so many seek a counterfeit at the price of a few beers. Christ wants His Church to be unshockable, democratic, permissive and filled with the real spirit--a fellowship where people can come in and say: 'I'm 


\section{Possibilities for the Church}

It is well known that there are certain dynamics sparked by a group of individuals interacting together as a unit that could never have been achieved by a lone individual. This phenomenon is described by behavioral scientists as an "increment of power." I This is a clear case of the whole being greater than the sum of its parts. A crude illustration is the wild force that is unleashed by a rampaging mob or street gang.

This increment of power generated by a group unit is recognized to be even more potent in the religious context:

Climactic for a picture of interpersonal relatedness is the great: church chapter in the Epistle to the Ephesians--chapter 4--with its matchless appeals for communal group unity. Even the most successful Group Dynamics Laboratory triumphs in creating interpersonal maturity are still foothills exemplars of what group dynamism can achieve when it takes form in a truly Christian fellowship. 2

It is observed that when love and mutual brotherhood are the goals then the purposes of the group continue to present a challenge. These goals never wear out. Furthermore, "When the sharing group provides opportunity for group members to help one another the concept of mutual brotherhood takes on new meaning." 3

sunk!' 'I'm beat!' A fellowship must exist where committed people can being to be honest with each other and discover the dimension of apostolic fellowship." Larson, pp. 20-21.

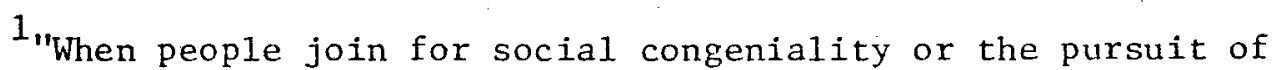
common interest, or even to serve some good cause they often discover an increment of power among them that seems to be something beyond the simple addition of their numbers." Casteel, p. 22.

2 John L. Casteel, The Creative Role of Interpersonal Groups in the Church Today (New York: Association Press, 1968), pp. 46, 47.

$$
\text { 3.eslie, p. } 123 .
$$


This is forcibly exemplified in the New Testament Church of which it has been said: "No doubt the early Christians found themselves augmented in some such way merely by being togehter." They stimulated one another's mind, stirred up energies and encouraged wills. ${ }^{1}$

In this connection it is important to note that the promise of Jesus' special presence and power ${ }^{2}$ was not made to a lone individual but to a group. The Master Himself admonishes: "Where two.or three or gathered together in my name, there am I in the midst of them." ${ }^{3}$ It was this special power through the presence of Jesus with the group that ensured Christianity's triumph over Rome: "Through the spread of its network of new and tough groups Christianity was able to set a term to the decay of the empire (Roman) and formed the matrix out of which a new society could be carved." 4

Undoubtedly the history of the success of the New Trstament

Church centered in the small group:

Such personal groups have been of great importance in the history of the early church. That history might be written as the account of the church's regeneration through the rise of small, tightly knit, deeply dedicated bands of people. The church began in a group of twelve, called by their Master 'to be with Him and to be sent out.' 5

I"That first group fellowship, like those that came after it, was animated by a spirit of love and of loyalty. . . Out of that came their tremendous spiritual power." Casteel, Spiritual Renewal Through Persona1 Groups, p. 168 .

2"And behold I send the promise of the Father upon you; but tarry ye in the city of Jerusalem, until ye be endued with power from on high." Luke 24:49.

$3_{\text {Matt } 18: 20 .}$

4 Homans, p. 650.

${ }^{5}$ Casteel, p. 20. 
This is doubtless reminiscent of the fact that almost every religious awakening or reformation in the history of Christianity originated with some dynamic, dedicated small group ${ }^{1}$--the religious orders of the Middle Ages, ${ }^{2}$ the pietistic movement of the seventeenth century, ${ }^{3}$ John Wesley's "Holy Club" at 0xford" (a prayer and study group which mushroomed into the Methodist movement), and most significantly, the Seventh-day Adventist movement which had its roots from its very inception in small groups known by the historic designation as "the little flock." 5

\section{Christianity supplies the key}

That Christianity supplies the key to the release of this increment of power for spiritual energy, growth and achievement is substantiated by experts in the group process:

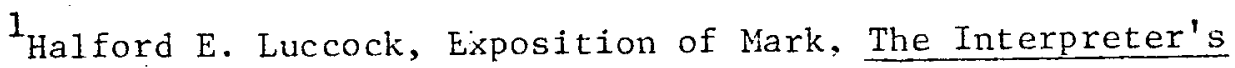
Bible (New York: Abingdon Press, 1951): 7:686.

2 Donald G. Blooesch, The Evangelistic Renaissance (Grand Rapids: William B. Eerdman Publishing Company, 1973), p. 103.

3 Leslie, p. 19.

4"The genius of the Methodist movement which enabled it to conquer the raw lives of working men in industrial England and the raw lives of men and women on the American frontier, was the 'class meeting'--ten members and their. leader, meeting regularly for mutual encouragement, rebuke, nurture, and prayer." Casteel, Spiritual Renewa1 Through Personal Groups, p. 20.

5 Mervyn Maxwe11, Moving Out (Mountain View, Calif.: Pacific Press Pub. Assn., 1973), p. 57. Speaking of these 1ittle groups which were to bedcome the foundation of Adventism (much the same way as Wesley's group became the foundation of Methodism), Maxwel1 informs us: "Before the end of 1846 several nuclei of believers in Sabbath, Sanctuary and Spirit of Prophecy had formed in scattered places. around New England and in the state of New York. . . " Te11 It to the World (Mountain View, Calif.: Pacific Press Pub. Assn., 1977), p. 86 . 
The religious group has a strategic position for it is consciously or unconsciously related to the release of creative emotions. It can direct a group towards mature and helpful action rather than stimulate a reversion to more primitive and injurious emotion. . . Where interest in the needs of others is inspired, the action of the group tends to become self-sacrificing and heroic. 1

It is this key, self-sacrifice, that makes, the difference; hence the need for "redeeming fellowship groups today." The sharing group, undoubtedly "offers the potential for meeting that need at the same time that it suggests a model for revitalizing the life of the church." 2

When God is made the central figure of group loyalty a new awareness of the significance of relationships emerges. ${ }^{3}$ Experiences have proved repeatedly that the average church anywhere can be greatly strengthened by the proper use of the power that is generated by such small groups. ${ }^{4}$ Not only will it help individuals to find deeper satisfaction in their church life, but the institution itself will be made more effective in achieving its stated goal. 5

Potential for church renewal and revitalization

In considering the potential that the group offers for church renewal and revitalization there are three ways in which small groups may provide growth and vitality in the church today--growth in fellowship, growth in personal Christian depth, and growth in mission

'Jackson, p. 11. The Alcoholics' Anonymous organization for example, utilizes this power of the group to find the suppore necessary to help individuals break the alcohol habit. Reid, p. 28.

2Leslie, p. 199.

${ }^{4}$ Reid, p. 11 .
${ }^{3}$ Ibid., p. 122 .

5 Ibid. 
(both in ministry and in witness). According to Clemmons and Hester these areas of growth will help provide new answers through the rebuilding of small sharing and caring units within the life of the church. ${ }^{1}$ This thought is also expressed by Jackson:

There is power in the group relationship that cannot be ignored. It can work for personality growth and individual development. It is important for church workers and church camp personnel to recognize and use these dynamic group forces that are available to them. ${ }^{2}$.

A. great advantage of the small group approach is the opportunity it offers to utilize the talents of nonprofessionals in the church as leaders: "The small sharing group can be led by selected laymen who are fitted for leadership, first by natural talents, and then by experience and training." ${ }^{3}$ It is observed that leadershi! skills are often caught as the members participate in groups led by trained leaders and then provide leadership of groups themselves. ${ }^{4}$

\section{Necessity for training}

The necessity for training small group leaders has been duly emphasized by Reid and others. Reid is emphatic in his assertion that: "There is no substitute for training." 5 . The importance of this training is implicit also in Luccock's declaration: "There is much to support the conclusion that all the great movements in christianity have been based on the training of small groups." 6

In this art of training we must emphasize the need for a close examination of the proper structure and purpose of groups, for

$$
\begin{array}{ll}
{ }^{1} \text { Clemmons and Hester, p. 45. } & { }^{2} \text { Jackson, p. } 15 . \\
{ }^{3} \text { Leslie, p. 133. } & { }^{4} \text { Ibid. } \\
{ }^{5} \text { Reid, p. 28. } & { }^{6} \text { Luccock, p. } 686 .
\end{array}
$$


"only if they are soundly based, efficiently organized and clearsighted as to their aims will they fulfill their vital role." ${ }^{1}$ This counsel is most timely inasmuch as there is grave danger when small groups are led by inept leaders or untrained and inexperienced persons. Such groups can result in more harm than good. ${ }^{2}$

Two other advantages that accrue from training small group

leaders may be described as (1) pastoral help, and (2) self-help:

Intelligent and compassionate lay leadership when properly trained can quickly take over the work of group leadership as it is actually the church and not the pastor alone assuming the responsibility for counselees completing the unfinished business of childhood and growing to productive and national maturity. Secondly it puts people to work solving their own problems-thoroughly and unhurriedly, and he is thus able to help as many simultaneously, as he used to pray that he could when he relied on conference-type pastoral counseling. ${ }^{3}$

Other mutual benefits for both preacher and small group may

be cited. For instance, when a pastor participates in the small

group program, he learns to krivw his people and their needs more

intimately since he receives valuable information of their emotional

needs and concerns. This enables him to make his preaching more relevant. 4

It also gives the layman an opportunity to express his

${ }^{1}$ Michael Skinner, House Groups (London: Epworth Press and SPCK, 1969), P. 1 .

2 A contemporary sociologist has remarked that: "Snall group discussions have become popular among evangelicals." He warned that they are an outgrowth of sensitivity training and can be risky if not handled properly. Tony Campolo quoted in "News: Evangelicals Employ Longabandoned Teaching Technique." These Times; October 1977, p. 6.

3 John B. Oman, Group Counseling in the Church (Minneapolis: Augsburg Publishing House, 1972), p. 12.

${ }^{4}$ Casteel, The Creative Role of Interpersonal Groups in the Church Today, pp. 113-14. 
opinions and impressions; at the same time it provides the pastor with feedback that is vital in the communication process. The opportunity to express himself also gives the layman the feeling that his personhood is more deeply involved, hence more of him is invested in the life and work of the institution. ${ }^{1}$

$1_{\text {Ibid. }}$ 


\section{CHAPTER IV}

\section{PROJECT DESCRIPTION}

\section{Pilot Program}

As a prelude to the project, a pilot program with a growth group was organized and conducted by the writer on the campus of Andrews University in the sumer of 1976. The composition of the group was heterogenous--men, women; the old, the middle aged, and the young; doctoral students, graduates, college, high school students; professional, and nonprofessional. This group numbered twelve individuals and met for two hours once a week for eight weeks.

From the very first meeting, through appropriate "icebreaking" exercises the atmosphere was created for deepening and growing fellowship.. The interest and enthusiasm grew with each passing week. More and more the group learned to "share," "bearing one another's burdens" as well as joys through the means of relational Bible studies. Passages of scripture were studied not only theoretically, for their content, but experientially--in what way does this apply to my personal experience? This approach to Bible study was new to almost all in the group.

As a result, a considerable measure of depth-leve1 sharing was developed in this relatively short period of time and a bond of fellowship was forged which, in our opinion, was nothing short of the New Testament koinonia. Frequently during this time different members 
of the group would ask, "Why don't they have something like this in the churches?" Members' satisfaction was most gratifying and the group responses were unanimous that this is what we need in the church to bring about meaningful fellowship.

\section{Approval of Institutions}

With the success of the pilot program, plans for the couse were finalized and submitted to the West Indies Union Conference officers whose territory was involved; to members of the Andrews University committee then in charge of directing the extension school in the M.A. program in religion at West Indies College; and to West Indies College itself, where the course would be conducted. The West Indies Union Conference officers expressed appreciation and pledged support for the course.

After obtaining certification of the writer's qualifications from the chairman of the Doctor of Ministry program to conduct such a course, the comittee in charge of extension M.A. program for West Indies College approved the course. They suggested the title: "Workshop in Leadership Development," and signified their willingness to give three graduate credits for it.

West Indies College welcomed the plan for the course and the administrators proceeded to built it into their summer-session schedule and to provide the necessary accommodation and facilities.

\section{Description of Course}

The course took the form of a two-week intensive session (or semi-marathon) from June 6 through 16. Eleven ministers and ministerial interns registered officially for the course while others 
visited as observers. Among those visiting were the president of the South Haiti Mission, the chairman of the theology department of West Indies College, the president of the West Indies Union, and Dr. Sakae Kubo of Andrews University. These participated freely and made valuable contributions to the discussions.

\section{Course agenda}

(1) Organizational preliminaries

(2) Reading material--advanced reading: six weeks prior to the proposed starting date, instructions were sent to the prospects via the theology department of the college to read certain books in the particular field of study in preparation for the course. Books suggested were: Church Meetings That Matter by Philip Anderson; Groups Alive--Church Alive by Clyde Reid; Group Counseling by Edgar Jackson, Sharing Groups in the Church by Robert C. Leslie; Groups That Work by E1ton Trueblood and others; Groups in Action by Lyman Coleman, and 69 Ways to Start a Study Group and Keep It Growing by Lawrence Richards.

\section{General information}

Our first class meeting convened on the campus of West Indies College, Monday morning, June 6, 1977. The scheduled time for starting was. 7:30 a.m. but we were a bit late in starting because of certain uncontrollable circumstances; this we made up for, however, by going over time. Thereafter the time schedule enjoyed a fair amount of respect.

The chairman of the theology department called the meeting to order, and after prayer he introduced the program and presented me to 
the group. Despite their warm reception and the general air of expectancy there were few who seemed just a little dubious or uncertain about the positive advantages of group dynamics.

Group contract. With the momentum of the reception received I lost no time in captializing on the opportunity to lay the foundation for building a warm group climate. This set the pace for negotiating the necessary group contract. The group cooperation was unanimous. No one was cajoled or coerced. However, it must be admitted that the prospect of getting three graduate credits was a powerful incentive for most of the men at the beginning. There was only one man who had already received his $M$.A. in religion from Andrews University, who was not taking the course for credit.

Classroom activities. Where procedural style is concerned meticulous care was exercised in avoiding the professor-lecturer student-1istener style so as to eliminate the formality. of the typical classroom atmosphere. Seats were so arranged that $I$ was on the same level with the group and shoulder to shoulder in the same circle as any one else.

Furthermore, I insisted that I be addressed by my first name without any title, as any one else. This gave them some struggle for the first two days but seeing that I was honest and comfortable with it they eventually relaxed and visibly enjoyed this symbol of comradeship. "Ordinariness disarms," declares Tjoard Jommes; "being on one and the same level allows for congeniality and collegiality." ${ }^{1}$ such a stance on the part of the group leader not only contributes.

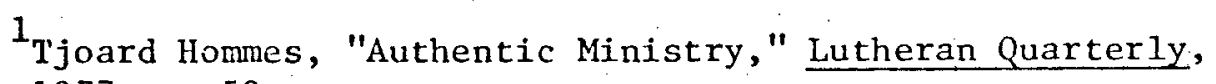
February 1977, p. 59. 
congeniality to the group atmosphere but also signals acceptance to the least member of the group. This is vitally important to the individual member.

Course material. The course material is divided into three sections for convenience handling: (1) Self-actualization, which deals with the motivation for joining groups. Under this section comes the material on the form and structure of groups; (2) Selfdisclosure, which deals with the importance of interpersonal communication for group interaction. Material dealing with communication skills comes under this section; (3) Self-transcendence--under this heading comes the last section dealing with leadership skills.

Lecture-discussion. The lecture-discussion method was modified and adopted to a "peer" setting, in other words, it was a discussion among equals--no boss, no lacky--hence the atmosphere was free, relaxed and informal as wuch as possible so as to stimulate normal and natural condition in churches (i.e., church halls, school, or wherever they hope to conduct similar group meetings with ordinary nonsophisticated people).

Hand-outs. Certain relevant materials were given regularly for which the men appeared to be most grateful.

$\underline{\text { Lab sessions. laboratory sessions were conducted, reinforced }}$ with various group exercises to provide opportunity for the group to apply in a practical way the theoretical concepts disclosed in the class. Time was then taken for personal evaluation as well as group evaluation.

Tape recording. Certain sessions were tape-recorded to 
afford the group leader opportunity for critical evaluation as well as to aid his recollection.

Method of evaluation. The formative-evaluation process coupled with the Likert's Attitude Test was used for general evaluation of the class as a group.

Celebration. The last session was climaxed by a very solemn and meaningful celebration of the Lord's supper. This also marked a joyful celebration of the tremendous success of the group experiences in which we had shared together in genuine koinonia.

\section{Course design}

The daily class format remained basically the same throughout (except for the fjrst day). We met for four-and-one-half hours each day. This block of time was divided into two--the first half for lecture-discussion and the other half for lab session. However, the fresh insights each day and the challenges offered by the possibility and practicability of group dynamics awakened such interest and excitement in the group that there appeared to be no time for boredom. The daily sessions followed in general the format outlined below: $7: 30-7: 45$ Devotion (conducted by a different person each day)

$7: 45-8: 15$

$8: 15-9: 00$

$9: 00-9: 10$

$9: 10-10: 00$

$10: 00-12: 00$
Organizational preliminaries

Removing our masks (getting better acquainted through the appropriate group exercise)

Break

Lecture-discussion: theoretical and theological rational for small group process

Lab session 
The daily class sessions

In the following pages are described in some detail each day's class activities beginning with the second day, since the first day of orientation has already been outlined. The instruction was thematically divided into three divisions--self-actualization, selfdisclosure, and self-transcendence. The essence of the growth group appears to be represented by these three interrelated ideas.

\section{Summary of Course Content and Activities}

Self-actualization, days $2-3$

Self-actualization constituted the rationale and underlying theme of the first two days. A statement on this theme is. followed by a description of two days classroom activities. ${ }^{1}$

The concept. Self-actualization, which deals directly with the essential needs of human nature, may be legitimately considered as the theoretical rationale for the type of group with which this project is concerned. (Self-disclosure and self-transcendence, which may be considered, in very simplified terms, as the method and process of the achievement of self-actualization respectively within the context of group dynamics, will be discussed in connection with the appropriate sessions).

Self-actualization may be defined as "the basis tendency for individuals to actualize their potential." 2 It is the psychological

${ }^{1}$ See appendix A for a sample class lecture.

2 Thomas Gordon, Group-Centered Leadership (Boston: Houghton Mifflin Company, 1955), p. 54. 
need for growth, development and utilization of one's potential. ${ }^{1}$ In other words:

We can say, an organism is governed by the tendency to actualize, as much as possible, its individual capacities, its 'nature,' in the world. . . . This tendency to actualize its nature, to actualize itself, is the basic drive, the only drive by which the life of the organism is determined.?

The concept of self-actualization as the underlying principle of growth groups may be best illustrated by citing three of the hypotheses undergirding the Human Potentialities Movenent: (1) that the group environment is one of the best settings in which to achieve growth; (2) that man's most exciting life-long adventure is actualizing his potential; (3) that personality growth can be achieved by anyone willing to invest himself in this process. 3

Behavioral scientists agree that the basic motivational principle that operates in human beings rests solely on certain fundamental needs. 4 Abraham Maslow advanced the view that these needs form a hierarchial structure. ${ }^{5}$ At the base is the physiological needs or drives--the impulse to satisfy hunger, the desire for survival and security; then higher up on the ladder are sociological needs--need to belong, need for esteem; and at the apex are the

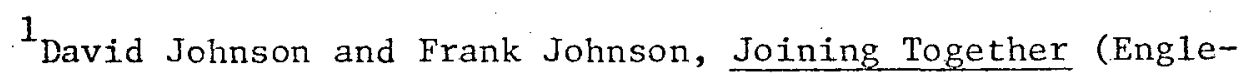
wood C1iffs, New Jersey: Prentice-Ha11, 1975), p. 289.

2 Kurt Goldstein, The Organism (New York: American Book Company, 1939), p. 196.

3 Leslie, p. 18.

${ }^{4}$ W. E. Beveridge, Managing the Church (London: SCM Press, 1971), p. 44 .

${ }^{5}$ Abraham Maslow, Motivation and Personality (New York: Harper and Brothers, 1954), p. 13. 
psychological (and spiritual needs)--self-actualization. This is the desire to excell and to achieve.

The consensus among sociologists and psychologists on the point seems to be clearly expressed by Johnson: "Man's highest need is desire for self-actualization." 1 Behavioral scientists and advocates of group dynarics claim that individuals through their selfawareness "and intentionality have self-actualization or self- : realization as their end goal in 1 ife. " 2 Johnson explains in detail: Self-actualization involves both self development and selfutilization--that is, potentialities are developed and then used in order to actualize oneself. Much of the focus of selfactualization in growth groups is aimed at greater personal understanding and awareness, and an increased sensitivity to both the surrounding environment and other people. ${ }^{3}$

Thus people join groups, because they perceive them as possible means for self-actualization--a way of actualizing their own capacity. On the other hand a group promises the individual an opportunity to grow, develop, fulfill, enhance, create--or "simply to become that for which he has the potential." ${ }^{4}$ Clinebell confirms this . view and sees the group "as an interpersonal laboratory for one's growth-work." Emphasizing the necessity for "depth relationship" to create the climate for growth he declares:

The small sharing group is the ideal for deepening relationships and consequently accelerating growth. To continue growing, every person requires a depth relationship with at least one other human being. A small network of depth relationship is

$$
\begin{array}{ll}
1_{\text {Johnson and Johnson, p. } 289 .}{ }^{2} \text { Ibid. } \\
{ }^{3} \text { Ibid. } & { }^{4} \text { Gordon, p. } 55 .
\end{array}
$$


even better. The group is an interpersonal laboratory for testing and learning better ways of relating. It provides a place to do one's growth work. 1

It is no mere passing coincidence that the behavioral

scientist and theologian alike in discussing "a person's basic needs" in the context of a committed relationship emphasize "oneness with others" which they define as "fellowship." 2

We, therefore, conclude: "When we enter into dynamic relationship with others, we are stimulated to discover who we are, what we are doing, and other vital questions of concern to growing Christians." 3

Activities. On day 2, before introducing the subtopic in continuation of the lecture and discussion on the small group process, a few minutes were sept in review of the previous day's discussion. We then gave consideration to some fundamental principles underlying group procedures, emphasizing self-actualization as the chief motivation for joining groups.

The various definitions and usages of the expression, "group

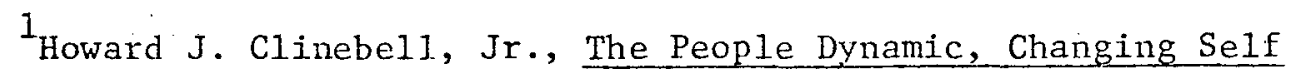
and Society Through Growth Groups (New York: Harper and Row, Pub1ishers, 1972), p. 8 .

${ }^{2}$ Dr. W. John Cannon, chairman of the behavioral science department at Columbia Union College, Takoma Park, Maryland, looks at commitment from a biblical perspective as well as from the behavioral science perspective, since he holds degrees in both fields. He shows how God's and Christ's commitment to the human family should be a model for human beings' commitment and to one another. "Commitment," Review and Herald, September 29,1977, pp. 3, 6.

3 Norman E. Jacobs, Christians Learning for Christians Living (St. Louis: Christian Board of Publication, 1956), p. 48. 
dynamics," were considered. Next were such topics as group size, response bonds and types of groups.

During the lab session, the class was involved in the following group exercises: History Giving, (2) affirmation--namegiving exercise, and (3) relational Bible study--the transfiguration (see appendix C). A season of sentence prayers brought about the dismissal. (See appendix D for hand-outs).

The next day, after reviewing the high points in the previous day's lesson considerable time was spent in discussing the various aspects of group behavior with demonstration in role-playing.

The lab session consisted of: (1) History Giving, (2) Affirmation, and (3) relational Bible study--the Pharisee's Prayer, Luke 18:9-14 (appendix C). After a reasonable amount of sharing within each group we dismissed with prayer--each man prayed for the one on his left. (See appendix D for hand-outs).

Self-disclosure, days $4-6$

Self-disclosure was the theme of the instructional materials used in the next three days. ${ }^{1}$

Self-disclosure may be considered as the key to unlock the secret of successful depth-level communication ${ }^{2}$-the indispensable key to the most relationship. ${ }^{3}$ It is only. at this level that section.

${ }^{1}$ See appendix B for a summary of the theory content of this

2 Those of use who can create conditions wherein mutual selfdisclosure is possible will communicate effectively--other will not." John W. Keltner, Elements of Interpersonal Communication (Belmont, Calif.: Wadsworth Publishing Company, 1973), p. 55.

${ }^{3}$ He claims that self-disclosure is the basis of our inter- 
growth in a real sense is experienced or desirable change effected. 1 This is the goal towards which the group process strives and, therefore, in a sense can be regarded as supplying the methodology by which the group hopes to reach the ultimate in group goals---spiritual growth "toward wholeness of self," 2 towards full functioning of all the individual's capacities, "towards confidence in the face of the external world at the same time that he can accept his deepest, real, unconscious self." ${ }^{3}$

To arrive at this depth-level relationship is the real challenge of group process. ${ }^{4}$ The task is made more tedious because the only available tool in the entire process is the delicate art of interpersonal communication ${ }^{5}$-delicate or difficult because of

action with other people. Revelaing ourselves is the means of achieving more effective communication. Ibid., p. 59. "Relationships are built on communication, both verbal and nonverbal." Viegmeyer, p. 12 .

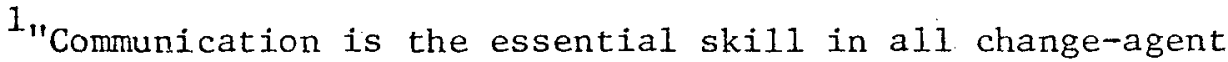
activities. Relationships constitute the instrument of change. Communication is the means by which relationships are established, maintained, or destroyed." Seifert and Clinebel1, p. 110.

2 Leda Sauliner and Teresa Simard, Personal Growth and Interpersonal Relationship (Englewood C1iffs, New Jersey: Prentice-Ha11 Inc., 1973), p. 33 .

3 Ibid.

4"You cannot form any significant or realistic image of me unless I am willing to reveal myself to you. Speech or communication is a means of achieving valid images of each other through selfrevelation and feedback. . . . Speech communication begins within. the self and its relationship to another." Keltner, p. 59.

5 "Relationships are built on communication, but on a special kind--personal communication." Wegmeyer, p. 16. 
certain "blocks" which must be recognized and overcone. 1

Communication blocks. Among the communication blocks the following are often cited: the mask, person perception, and self-worth. Car1 Rodgers, in his allusion to "the masks people wear," points out the pretenses they indulge to hide their real personal feeling or the facade they erect for preventing exposure of the true self to others. Paradoxically, however, these were behaviors learned in childhood to become permanent lifestyle. 2 So this "game" which people play" in which we cloak our real action behind the facade of adult behavior is really just an outgrowth of behavioral tactics practiced from childhood until now we have become real professional experts in stroking. ${ }^{4}$

Another factor that can be a dangerous block in the bridge of interpersonal communication unless it is properly handled is what the theorists call "person perception."5 Implied in this term are two distinct aspects of perception--social perception and self-perception. Social perception refers to the

l"If effective communication produce change through relationships, it behoves the change-agent to become cognizant of the blocks to meaning-transmitting communication." Siefert and clinebell, p. 116.

2Keltner, p. 27.

3aylor McConnell, Group Leadership for Self-realization (New York: Petroce11i Books, 1974), pp. 26-30.

4"Stroking may be employed colloquially to denote any act implying recognition of another's presence. Hence a 'stroke' may be used as a fundamental unit of social action. An exchange of strokes constitutes a 'transaction' which is the unit of social intercourse." Eric Berne, Games People Play (New York: Grove Press, 1964), p. 15.

${ }^{5}$ Giffin and Patton, p. 56. 
impressions we form of other people as we perceive them (rightly or wrongly) and the reactions to them as a result of these impressions which automatically influence the course of interpersonal communication. 1

This is evident when it is realized that social perception forms the basis for the "process of projection" or empathy, an indispensable link of meaningful commication. ${ }^{2}$ It is quite obvious that if we are to attempt to understand other people, then, we "must go to the center of their world and see as they do." Conversely, if we really are to understand our own selves we must be willing to get information from others about ourselves. ${ }^{3}$ Maslow supports this idea when he says that: "The best way of understanding another human being, or at least a way necessary for some purposes, is to get into his Weltanschauung and to be able to see his world through our eyes. 14

The third block, self-worth (or self-esteem), is twin sister to self-perception. Both are developed from one common base--the self-image. The development of a desired self-esteem or self-worth depends on a healthy self-image. 5

The process by which self-image or self-identity is developed begins in childhood and continues through life, for self-

$$
{ }^{1} \text { Ibid. } \quad{ }^{2} \text { Ibid., p. } 72 .
$$

3eltner, p. 42. "Behind the mask.. . there is the real person--very often quite different from the person we appear to be. And sometimes, the only way we can discover who we really are is to reveal ourselves to others and let them tell us who we are." Lyman Coleman, Serendipity: A Mini Course in Personal Relationships (Waco, Texas: Creative Resources, 1971), p. 14 .

${ }^{4}$ Abraham Maslow, Toward a Psychology of Being (New York: Van Nostrand Reinhold Company, 1962), p. 13.

${ }^{5}$ Giffin and Patton, p. 30 . 
identity can be described as the direct product of social interaction. Erik Erikson states:

- . identity formation . . is a lifelong development largely unconscious to the individual and to his society. Its roots go back all the way to the first self-recognition: in the baby's earliest exchange of smiles there is something of a selfrealization coupled with a mutual recognition. 1

Logically, children's concept of self-image and subsequent self-worth is influenced by their parents and significant others. ${ }^{2}$ Later on, however, as we develop from childhood to adulthood we tend to form more of our beliefs about ourselves through feedback about ourselves from others. We use these for comparing ourselves with norms and averages as well as with members of reference groups. 3

Mead advances the thought that each interchange gives us clues about how others see us and this shapes our view of ourselves. ${ }^{4}$ This view of ourselves, the basis for self-esteem, whether appropriately or narcissistically (an inflated view of one's self image), affects the tenor of interpersonal communication one way or the other. "Low self-esteem makes for dysfunctional communication." Conversely, "poor communication increases low self-esteem. "5

$1_{\text {Erik Erikson, "The Problem of Ego Identity," Psychological }}$ Issues 1 (January 1959): 47.

2 Hugh Duncan, Communication and Social Order (New York: Bedminster Press, 1962), pp. 271-73.

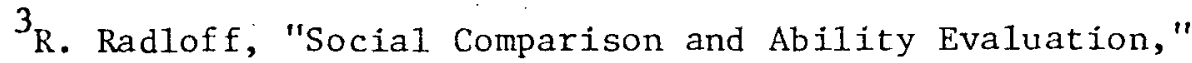
Journal of Experimental Social Psychology Supplement 1 (1966): 6-26.

${ }^{4}$ George H. Mead, Mind, Self and Society (Chicago: University of Chicago Press, 1934), pp. 144-64.

${ }^{5}$ Seifert and Clinebel1, p. 117. 
It is interesting to note at this point the mutual role between one's impression of his self-image (or self-identity) and interpersonal communication. "Every time we initiate communication or respond to it, we also make this request: 'Please validate me-confirm my viewpoint and indicate my value as a person""--the basis of self-esteem. ${ }^{1}$

This interaction, therefore, helps us to develop appreciation for one's uniqueness. But appreciating one's uniqueness implies appreciating the uniqueness of others. ${ }^{2}$ That is to say, one's accurate self-worth or self-esteem provides the scales for his accurate self-worth of others; thus, self-worth can facilitate interpersonal communication or "block" it, depending on the individual's self-concept.

The scare of unmasking. Self-disclosure naturally involves the risk of vulnerability ${ }^{3}$ by self-exposure ${ }^{4}$ unless there is a certain atmosphere of safety and confidentiality. 5

Behavioral scientists emphasize the point that behind our defenses there is a fear of intimacy:

Behind these defenses against knowing there is often a fear of intimacy. Intimacy means sharing, and sharing means exposure. There is something irrevocable about this sharing--something that binds one to the confidant. . . . Some shy away from sharing because they . . feel they have too much to hide. 6

$$
\begin{aligned}
& { }^{1} \text { Giffin and Patton, p. 26. } \\
& { }^{3} \text { Keltner, p. 54. } \\
& 5_{\text {"Experiencing our feelings of ten seems too dangerous, too }}
\end{aligned}
$$
potentially damaging. It is only in an atmosphere of safety and freedom that feelings can be experienced fully." Saulnier and Simard, p. 41 .

$$
6 \text { Wegmeyer, p. } 27 .
$$


We are often faced with the "dilemma of trust." As Philip Anderson and Phoebe Anderson put it: "We are often afraid, suspicious, cautious, safety conscious, hesitant, waiting for the other person to prove himself trustworthy." 1 To build this required safety atmosphere, therefore, certain elements are absolutely vital. Some of these are: supportive group, confidentiality, trust, acceptance, authenticity, affirmation. Because we tend to barricade ourselves behind the facade of our cultural pretenses, and hide our loneliness and isolation under the mask of our stoic independence for fear of rejection ${ }^{2}$ we need a supportive group in which people of mutual interest and mutual goals are committed to one another in a group contract:

There's some kind of inexorable law that spiritual development comes only on a person-to-person basis. It has to operate through individuals as the molecules of the structure, and this necessitates creating an atmosphere of trust such as small groups provide. 3

With such a group of committed persons the skillful use of certain "ice-breakers" can quickly tear down the artificial barriers of cold formality and traditional timidity and facilitate confidentiality. The more members of the group interact. with one another, the more ground they find to appreciate one another; thus confidence is built up. This is laconically expressed in the words of Vernon

${ }^{1}$ Philip Anderson and Phoebe Anderson, The House Church (New York: Abingdon Press, 1975), p. 49.

2 John B. Oman, Group Counseling in the Church (Mineapolis: Augsburg Publishing House, 1972), p. 83 .

3 Walden Howard, Nine Roads to Renewal (Waco, Texas: Word Books, 1967), p. 150 . 
Howard: "Familiarity breeds confidence." 1

Trust is described as : "Putting one's life in the hands of another person or persons." 2 There is mutuality in a relationship of trust. As each one becomes "increasingly transparent about his thoughts, his feelings, and his actions, he discovers he is even more deeply loved and affirmed." ${ }^{3}$ People cannot know themselves (and others) without dialogue and self-disclosure to someone they trust. ${ }^{4}$. Trust, then, grows hand in hand with love.

Acceptance is another element that is integral to the process of self-disclosure. This involves two sides like a pair of scissors--self-acceptance (which grows out of self-perception as already noted) and acceptance of others. 5 Jung states: "Acceptance of oneself is the essence of the moral problem and the acid test of one's whole outlook on 1ife." 6

The complete acceptance of one's self is the necessary

prelude to the unconditional acceptance of others.

The acceptance of self permits the person to accept himself as. as he is at any given moment . . allows understanding of what is known and familiar to the person, thus preparing him to

${ }^{1}$ Vernon Howard, Your Magic Power to Persuade and Command People (Englewood Cliffs, New Jersey: Prentice-Ha11, 1962), p. 112 .

2 Sidney $M$. Jourard, The Transparent Self (New York: Van Nostrand Company, 1964), pp. 3-6.

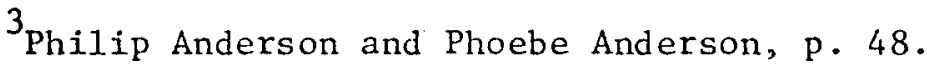

${ }^{4}$ Ibid., pp. $48-49$.

${ }^{5}$ Cecil Osborne, The Art of Understanding Yourself (Grand Rapids: Zondervan Publishing House, 1973), p; 28.

${ }^{6}$ Ibid. 
accept others (especially God whom he knows 1ess).

The acceptance of the other is the extending of our selfacceptance to others so that we can interact and accept them as fully responsible members of their own life-way.

Mutual respect involves balanced reciprocity in interpersonal relations leaving both persons intact and valid.1

The first principle of interpersonal relationship is to express love to others as unconditional acceptance. It is important to note that Jesus sets the example in the gospel which is "the good news of God's announcement of this unconditional acceptance of the sinner. ${ }^{2}$

Authenticity is another essential element that must be mentioned in any discussion of self-disclosure as part of the interpersonal communication process. This refers to the honesty, openness and frankness of the individual, or what Sidney Jourard terms, "The transparent self." ${ }^{3}$ One must be "genuine, open and sincere" in order to relate successfully to others. Such a stance necessarily involves humility. ${ }^{4}$

Authenticity (the authentic self) is somewhat allied to trust and acceptance in that to get the love we seek, we must disclose that which is important to us. Only then can we be fully accepted. "If we still feel unaccepted or unacceptable," says Howard, "the chances are that there is still a part of us which we have not entrusted to others." Honesty is vital to trust:

$1_{\text {Marvin K. Mayers, Christianity Confronts Culture (Grand }}$ Rapids: Zondervan Publishing House, 1974), p. 30.

2 Barlow, pp. 56-57.

${ }^{3}$ See above, p. 77 , n. 3 .

4 Barlow, p. 63. 
To trust others with all. one's life is a choice each person makes in each relationship. There are things one doesn't do and things one does do. One does not give up one's identity, submit to others' wishes, persuade or conceal in order to avoid disapproval, falsify oneself for the sake of phony peace and harmony. A person strives to be himself openly, freely. 1

Affirmation is an additional guarantee of the safety of the group atmosphere because it communicates to each person the fact that he is important ${ }^{2}-{ }^{\prime}$ you are loved." Richards describes affirmation as "what happens when you and I see each other as valuable and worthwhile, when we communicate this perception to each other." 3

When these elements are present in the right proportion the desired atmosphere will be created conducive to mutual selfdisclosure. This is the essence of interpersonal communication which may be considered as the umbillical cord of interpersonal relationship. Not until this depth-level quality of communication is developed can meaningful relationship be established for "mind will only perfectly discover itself in other minds; therefore fellowship is the true norm of value, and love its perfect realization. "4

Activities. On day 4 , about ten minutes were spent in

$1_{\text {Philip Anderson and Phoebe Anderson, p. 48. "The more }}$ dishonest a person is the less he can relate effectively." Barlow, p. 63 .

2 Jesus inspired a sense of self-worth in people: "He passed by no human being as worthless. . . He taught all to look upon themselves as endowed with precious talents, which if rightly employed would secure for them eternal riches." Ellen G. White, Desire of Ages (Washington, D.C.: Review and Herald Pub. Assn., 1940), p. 66 .

3 Lawrence 0 . Richards, 69 Ways to Start a Study Group and Keep It Growing (Grand Rapids: Zondervan Publishing House, 1973), p. 49 .

$$
{ }^{4} \text { Barlow, p. } 55 \text {. }
$$


recapitulation of the main points relative to various aspects of group behavior-formation, stages, interaction, and goals. The second major division of the study was entered in. This dealt with the basic skills of interpersonal communication and was discussed under the term "self-disclosure."

We started with the subtopic dealing with the problems of expression--words, ideas, feelings, and the matter of congruence versus incongruence. A very'stimulating discussion followed. Questions from the group were intelligent, thus revealing a significant depth of perception.

In the $1 \mathrm{ab}$ session, the group was involved in: (1) History Giving--drawing my world in colors to express my overall outlook on 1ife, (2) Affirmation--The Lift (verbal and nonverbal exercise), and (3) relational Bible study--Peter's experience, Matt 26:30-35, 38, 69-75, NEB (appendix C). (See appendix D for hand-outs.)

On day 5, following the devotion given by a member of the group and the usual review of the highlights of the previous day's topic by the author, we continued the lecture-discussion on interpersonal communication and its importance in establishing interpersonal relationship.

The matter of interpersonal trust, acceptance and.conflict was dealt with at some length, interspersed by many penetrating questions from the group. (Some of the points were highlighted with the aid of an overhead projector.) The differences between intrapersonal communication, interpersonal communication, and metacommunication were also discussed and illustrated.

of interest also was the "consistency theories" in "resolving 
cognitive dissonance"--the balance theory of Heider- the congruity theory of Osgood and the cognitive theory of Festinger (i1lustrated on the overhead projector).

The lab session consisted of: (1) Affirmation exercise, and (2) Relational Bible study--The Storm on Galilee, Mark 4:35-41, NEB .

A prayer of thanksgiving was offered on behalf of those who celebrated the victory in their particular storm and a petition was offered for Jesus to still the storm for those for whom it was still raging, and then the group was dismissed. (See appendix D for handouts.)

On day 6, the devotion was followed by the usual review of the previous day's activities. Continuing the discussion on effective communication as an indispensable vehicle for meaningful interIersonal relationship, the various levels of communication were illustrated. Other aspects of communciation such as nonverbal or body language, and tactics were also discussed.

Considerable time was spent in discussing the art of listening not only with the ears but moreso with the eyes and heart; not only for words but for ideas and emotion. This brought us to the subject of an interpersonal communication model of and variables in human communication. Diagrams of one-way versus two-way communications were shown on the transparency. (The group appeared to be excited as they grasped these new concepts, especially as they participated in group exercises of role playing, feedback and paraphrasing, perception, check, behavior description, feeling description and other transactional skills.) A transparency on the overhead 
project illustrated "mind-raping" (appendix D).

The men were so excited in mastering these skills that they utilized every opportunity to practice them on each other. This made them distinguishable on the campus by their special vocabulary-"noise in the channe1," "perceptual accuracy," "mind-raping," and others.

The $1 \mathrm{ab}$ session consisted of: (1) Nonverbal exercise-The Lift, and (2) Relational Bible study--Peter's vision, Acts 10, NEB (Appendix C). The session was closed with a season of sentenceprayers. (See appendix D for hand-outs.)

Self-transcendence, days 7-10

The final four days focussed particularly on group leadership. ${ }^{1}$ In introducing this portion of the relevant literature surveyed for leadership training, it seems appropriate to borrow the word self-transcendence ${ }^{2}$ as the most comprehensive term to express the demanding qualities requisite for group leadership. It is obvious that this type of leadership is more exacting than the leadership expected of social clubs, secular organizations, or even the ordinary church groups. ${ }^{3}$ It requires a person's whole being in disinterested

${ }^{1}$ See appendix B for a summary of theory content for this section.

2 "Self-transcendence has become a fundamental category for interpreting the religious dimensions of human experience in contemporary theologies and philosophies of religion. ... 'Man achieves authenticity in self-transcendency." Walter E. Conn, "Persona1 Identity and Creative Self-understanding: Contributions of Jean Piaget and Erik Erikson to the Psychological Foundations of Theology," Journal of Psychology and Theology (Winter 1977): 35.

3 Philip Anderson, pp. 59-59. 
service; it demands an extension of self beyond al1 vested interest; it calls for a total giving of self for the life of the group. Indeed, it must transcend self because this type of leadership accepts as its model the greatest group leader of all time--our Lord, Christ Jesus. ${ }^{1}$

This perfect model for group leadership is the only valid basis from which to draw a clear concept of what the ideal group leader should be.

And there was a strife among them, which of them should be accounted the greatest.

- . but he that is greatest among you, let him be as the younger; and he that is chief, as he that doth serve. ${ }^{2}$

For even the Son of man came not to be ministered unto, but to minister, and to give his life a ransom for many. 3

This servant theme is the true biblical image of the ideal leader, "It is central to Christ's own life as He gives Himself to the brethren and to al1 mankind." 4

This type of group leadership, therefore, calls for men who are willing to be involved as "servant leaders," men who are willing to face the challenge laid down by Hendrik Kraemer to "place their task and vocation under the light of that profound, revolutionary work, diakonia (service)." This type of service he exalts from the mere ethical and humanitarian category into the deepest religious category, which lies at the bottom of the gospel. 5 John R. W. Stott

$1_{\text {Paul F. Douglas, The Group Workshop Way in the Church }}$ (New York: Association Press, 1956), p. 82.

2Luke 22:24, 26.

${ }^{4}$ Philip Anderson, p. 63.
3 Mark 10:45.

${ }^{5}$ Kraemer, p. 187. 


\section{4}

calls it "Leadership by service."1

This idea of selfless service forms the essence of growth group leadership, and as such expresses itself in certain principles that are crucial for the life of the group and the growth of the leader himself. These we shall now consider.

Extension of the self. This is the ability to look beyond the immediate needs and concerns of self-interest to the more important group interest. "The welfare of others becomes as important as the welfare of self. The mature person is able to participate, to identify and to strive for purposes larger than himself." 2 Warm interpersonal relationship. This implies the ability to love and interact with people in a warm way. It requires a certain amount of emotional maturity as Gordon Alport indicates:

The mature person is capable of intimacy and love. His interpersonal relationships are characterized by empathy and compassion rather than possessiveness and hostility. The rature person is able to give love, while the immature person wants to be loved. The mature person gives love rather than exchanges it. 3

The need for emotional maturity in interpersonal relationship is indispensable to the vitality of the group ${ }^{4}$ for a depressed, hostile, toxic leader is very likely to contaminate the group and stifle growth. On the other hand, "a nourishing leader thrives on

${ }^{1}$ John R. W. Stott, "Unhooked Christians," Christianity Today, October 7, 1977, pp. 40-41.

${ }^{2}$ Gordon W. Alport, Patterns and Growth in Personality (New York: Holt, Rinehart and Winston, 1963), p. 290.

${ }^{3}$ Seifert and Clinebe11, pp. 61, 62 .

${ }^{4}$ Maxwell Maltz, The Magic Power of Self-image Psychology (Englewood Cliffs, New Jersey: Prentice-Ha11, 1964, pp. 169, 170. 
joyous human interaction and is a self-nourisher who generates his own enrichment rather than feed on group members. " 1

Commitment to a shared leadership. The "servant leader" model is committed to a shared ministry (or leadership). ${ }^{2}$ Fred Fielder observes that the leader may assume primary responsibility for the group and become autocratic, controling, managing, directive and task oriented with members: Alternately, he can share decisionmaking and leadership with his group; he can be democratic, nondirective, considerate of members' feelings and therapeutic in his leadership. ${ }^{3}$ Thus he will create opportunities to educate and train members so that they can develop the skills and experience that will enable them to share the decision-making process and other responsibilities with him. 4

Identification. The group leader must be willing to identify rimself with other people. If he is mature enough to "see people as persons and not as things or objects" by which he advances his own self-interest; if he has learned to "talk with people and not at them;" $"$ if he has learned to assess the standard of success or failure so that the true value of selfhood may shine forth; ${ }^{6}$ if he has

Marilyn Bates and Clarence D. Johnson, Group Leadership (Denver, Colorado: Love Publishing Company, 1972), p. 43.

${ }^{2}$ Philip Anderson, p. 63.

3 Fred Fielder, A Theory of Leadership (New York: McGrawHill Book Company, 1967), pp. 10,11.

${ }^{4}$ Alfred H. Gorman, The Leader in the Group (New York: Bureau of Publications, Teachers College, Columbia University, 1963), p. 21.

5 Maltz, pp. 176-79.

${ }^{6}$ Adrian van Kaam, Editorial in Humanitas, June 13, 1977, p. 139. 
acquired the ability "to see others' point of view," then he will have no "identification problem."1

Projection. Projection, called by some "empathy" determines the basis for judgment and facilitates meaningful interpersonal communication. ${ }^{2}$ The leader must be able to project himself into people's specific situation and feel their emotional needs. People need understanding, acceptance, affirmation. ${ }^{3}$ The leader must, therefore, be able to give empathetic understanding. ${ }^{4}$ He must be able to demonstrate what Merle ohlsen calls "concreteness"--a precise, complete response to specific feelings and experiences. 5

Authenticity. One source defines "authenticity" as the ability to present "self rather than a role." 6 In other words it is a challenge to be one's true self. The pressure to be true reflects a general dislike for insincerity, "for elitism in any shape or form." 7 Thus the pressure for authenticity, or genuiness, in the sense of being what/who he really is, bears heavily on the outcome of group climate necessary for a trustful relationship. ${ }^{8}$ This is crucial for the life and success of the group.

Trust and acceptance. The spiritual growth group leader must

$1_{\mathrm{Maltz}}, \mathrm{p} .177$.

${ }^{3} \mathrm{Clinebe11, \textrm {p } .} 37$.

5 Merle M. Ohlsen, Group Counseling (New York: Holt, Rinehart and Winston, 1970), p. 3 .

6 Hommes, "Authentic Ministry," p. 58.

7 Ibid.

8 William Schutz, Joy: Expanding Human Awareness (Grove Press, 1967), p. 15 . 
be committed to a stance of basic trust and acceptance in group members. He must not only demonstrate faith and trust in the capacity of the group collectively, but he must trust in the individual members as well. ${ }^{1}$ His unconditional acceptance of people as they are without evaluation ${ }^{2}$ is also very vital. Not only must he be conscious of each one as a person but be willing to take time to "listen without judgment, ${ }^{3}$ without signs of shock at anything he might divulge. 4

Role-distancing. This is described by John H. Morgan as "the capacity of an individual to stand outside or above himself for the purpose of critical reflection. ${ }^{5}$ This exercise of role-distancing helps to nurture one's emotional we11-being much the same way as physical exercise improves the health of the body.

The importance of this exercise for the group cannot be overemphasized, for unless the grosp leader is sufficiently matured to master this challenge of role-distancing it is not likely that he can help the group in the periodic critical evaluation of itself, which is so vital to success. 6

$$
{ }^{1} \text { Gardner, p. } 91 \text {. }
$$

2 Dennis Blum, "Suicide--the Absence of Love," Review and Herald, October 20, 1977, p. 10.

3 "Never did He (Christ) utter one expression to show that His sensibilities were shocked or His refined taste offended." White, Ministry of Healing, p. 165.

${ }^{4}$ McConne1, p. 215.

5 John H. Morgan, "Pastoral Ecstasy and the Authentic Se1f: Theological Meanings in Symbolic Distance," Pastora1 Psychology 25 (Winter 1976): 132 .

$$
{ }^{6} \text { Oman, pp. } 31,32 \text {. }
$$


Activities. The remaining four days were devoted to the dynamics of group leadership which has been conveniently subheaded "self-transcendence."

On day 7 , after the preliminaries, the subject was introduced by the question: "Leadership; what is it?" The members of the group were allowed a few minutes to air their ideas before the leader turned to various definitions by some famous authors. Those were discussed in the light of the new dimension that each added to the leader concept, finally climaxing with the "Oligarchic Imperative" discussed by John H. Morgan.

The latter half of the session was spent in discussing the four basic approaches to leadership theory--trait, position, style, distributed functions. A diagram on the transparency added light and interest and the group members expressed that the new insights would be of tremendous help in their. leadership role in the churches.

The lab session involved: (1) Group exercise--Blind Wa1k, and (2) Relational Bible Study--Priorities, Luke 10:30-42 (appendix C). Each told of his plans for the future in order of his particular priorities; then the group prayed for each other, mentioning their priorities. (See appendix D for hand-outs.)

On day 8 , after the regular periods for devotion and review, we proceeded to a dilineation of the various leadership styles. This was further illuminated on the overhead projector.

The members showed signs (verbally and nonverbally) that they were favorably impressed, particularly as they recognized the implication for their own leadership style in the church in relation to the democratic and transactional models. 
Engaging our attention for the latter part of this session were Anderson's views of "The Servant Leader." 1 Emphasis was laid on the example of unselfish service set out by our Lord as a group leader.

During the lab session, the group was involved in: (1) Feedback cards, and (2) Relational Bible study--Love, 1 Cor 13:1-6, NEB (appendix C). A short season of prayer brought this meeting to a close. (See appendix D for hand-outs.)

On day 9, we began with a review of the previous day. Taking our cue for leadership role from the example laid down by the greatest leader of men, Jesus of Nazareth, we continued our discussion on the importance of the communication process--expression, listening and response--to the leader.

The latter half of the session was devoted to some detailed consideration, with examples of illustrations, of leader furctions such as traffic control (creating a psychological atmosphere for interpersonal interaction), the resolution of conflict, traffic directing (blocking gossip, blocking prying questions), "blocking the there and then," blocking invasion of privacy. For this latter the theory of the Johari window helped to clarify the concept (see fig. 1).

Emphasis was placed on the window marked "unknown to others." This window must never be pryed open. However, given the proper conditions in a group fellowship, feedback from the window, "known to others," to the window, "unknown to self" creates a mutuality in

\footnotetext{
${ }^{1}$ Philip Anderson, p. 63 .
} 


\begin{tabular}{|c|c|}
\hline $\begin{array}{c}\text { Known } \\
\text { to } \\
\text { self }\end{array}$ & $\begin{array}{c}\text { Unknown } \\
\text { to } \\
\text { self }\end{array}$ \\
\hline $\begin{array}{c}\text { Unknown } \\
\text { to } \\
\text { others }\end{array}$ & $\begin{array}{c}\text { Known } \\
\text { to } \\
\text { others }\end{array}$ \\
\hline
\end{tabular}

Stage 1--Represents the beginning stage at the formation of the group before group interaction picked up momentum.

\begin{tabular}{|l|c|}
\hline $\begin{array}{c}\text { Known } \\
\text { to } \\
\text { self }\end{array}$ & $\begin{array}{c}\text { Unknown } \\
\text { to } \\
\text { self }\end{array}$ \\
\hline $\begin{array}{l}\text { Unknown } \\
\text { to } \\
\text { others }\end{array}$ & $\begin{array}{c}\text { Known } \\
\text { to } \\
\text { others }\end{array}$ \\
\hline
\end{tabular}

Stage 2--Shows the windows start moving toward equalizing known and unknown areas as group interaction begins to facilitate "sharing and feedback."

\begin{tabular}{|l|c|}
\hline $\begin{array}{c}\text { Known } \\
\text { to } \\
\text { self }\end{array}$ & $\begin{array}{c}\text { Unknown } \\
\text { to } \\
\text { self }\end{array}$ \\
\hline $\begin{array}{c}\text { Unknown } \\
\text { to } \\
\text { others }\end{array}$ & $\begin{array}{c}\text { Known } \\
\text { to } \\
\text { others }\end{array}$ \\
\hline
\end{tabular}

Stage 3--Shows the progress of equalizing as the progress of group interaction results in deeper level of sharing and feedback.

\begin{tabular}{|c|c|}
\hline $\begin{array}{c}\text { Known } \\
\text { to } \\
\text { self }\end{array}$ & $\begin{array}{c}\text { Unknown } \\
\text { to } \\
\text { self }\end{array}$ \\
\hline $\begin{array}{c}\text { Unknown } \\
\text { to } \\
\text { others }\end{array}$ & $\begin{array}{c}\text { Known } \\
\text { to } \\
\text { others }\end{array}$ \\
\hline
\end{tabular}

Stage 4--Shows the final stage as the goals of group interaction are realized in Koinonia. Note the expansion of known areas as the unknown recede to the basics. The partition of the window is now in reverse of the beginning.

Fig. 1. Johari window application 
which window "unknown to others" will gradually open by its own volition.

The lab session consisted of: (1) Group exercise--Trust Circle, and (2) Relational Bible study--Paraphrase Heb 10:23-25, NEB, in the light of personal experience (appendix C). (See appendix $D$ for hand-out.)

On the last day the group gathered in an atmosphere of mixed feelings. The morning devotion was especially meaningful. Like the disciples we had been in the Upper Room for ten days--ten days of unprecedented fellowship, study, prayer, tears, and laughter. But now we had come to the end, and for the climax we had plans for a communion service that night.

Concluding our course of study on this last day was an interesting discussion on the qualities and characteristics of a successful group leader. Qualities such as perception, sensitivity, respect, genuineness, concreteness, courage; and characteristics such as acceptance, honesty, responsibility, extroversion, composure, supportiveness, et cetera, were emphasized. Finally the need for the group leader to always exemplify the principles for which the group stands was duly stressed. Instruments for evaluating the group process were administered at the close of the session.

During the lab session, class members participated in: bombardment, and (2) Relational Bible study--Spiritual Encounter, Acts $12: 1-17 \cdot$ NEB (appendix C).

Interlocked in a group hug each man prayed for the one on the left, finishing with the closing prayer by the group leaderinstructor. We adjourned until 7:00 p.m. when we reassembled for a 
most fitting climax with the celebration of the communion service.

The atmosphere at this last session was warmed by a keen sense of the "fellowship and communion of the Holy Spirit" binding our hearts together in that genuine oneness or real koinonia.

Following the celebration of this communion service, speeches of appreciation for the course were spontaneously given by members of the group. These ministers were quite eloquent in their expressions of gratitude for the "insights and new concepts gained," as they put it, "that will be most beneficial to our work in our churches."

The meeting ended with the members clasping each other's hand in a circle, singing in a group song and offering volunteer prayers; but this group of ministers departed with a vision of the power that their church can become through koinonia and a determination to enjoy the new tools and skills acquired in enhancing the effectiveness of their ministry in their churches. (See appendix D hand-outs.) 


\section{CHAPTER V}

EVALUATION, IMPLICATIONS, CONCLUSION, AND RECOMMENDATIONS

This last chapter will be concerned with an evaluation of the project, implications for the church as well as for the writer, and conclusions with respect to the project. Some specific recommendations which should be helpful to the church on a whole will also be made.

\section{Evaluation of the Project}

It was not my intention ${ }^{1}$ for the project to produce any cagree of immediate measurable results in the field. Measurable results in terms of statistics, I am confident, will accrue in due time but that may be the subject of a later report. The nature of the present project did not lend itself to specific measurement with sophisticated instruments in terms of "control" and "comparison" or statistical change.

In keeping with the nature of this project I deemed it more practical to employ the "Formative-evaluation Process" for evaluating its progress. This method of evaluation lends itself readily, and certainly more practicably to this type of project, particularly in

$1_{\text {Because the naturalness of the first person pronoun lends }}$ itself to the materials in this chapter, the more objective third person style is dispensed.with here. 
view of the goals that were intended. These goals were specifically related to the learning situation, attitudinal change and pedagogical methodology (in relation to the teacher himself).

These are the three precise areas that fall within the scope of this method of evaluation.

The formative-evaluation process

This process involves evaluation during the progress of the course construction, teaching or learning. By this process of evaluation the teacher (or group leader) can observe any improvement in any one or more of the three areas. This evaluation technique, then, becomes an ongoing process in the class or group situation. "Formative-evaluation involves the collection of appropriate evidences during the construction and trying out of a new curriculum in such a way that revision of the curriculum can be based on this evidence." 1 This is especially improtant since I hope to conduct similar-raining sessions throughout the West Indies Union Conference. I, therefore, endeavored to make careful evaluation of my methodology and the effects on the subjects' responses as an ongoing process during the classroom sessions, and after each session in the effort of self-evaluation, reexamined my pedagogical techniques in the context of the group process.

\section{Likert-type attitude test}

Relative to the evaluation of the learning process, behavioral

${ }^{1}$ S. Bloom, J. T. Hastings, and G. F. Madaus, Handbook on Formative and Summative Evaluation of Student Learning (New York: McGrawHill Book Company, 1971), p. 116. 
scientists agree that the two aspects involved--cognitive and affective--are equally important. However, because the latter implies subjectivity (as opposed to the objectivity of the former) it is generally more elusive to specific measurement and, therefore, tends to be overlooked by some educators in favor of the readily measurable cognitive.

However, notwithstanding the complexity method has been developed the affective (or attitude), one particular method has been developed that is widely used in studies of this nature. This is the Likert method of summated ratings. ${ }^{1}$ This method consists of using one stimulus statement at a time that elicits response from the subject indicating the degree to which he may agree or disagree with that particular statement. This is usually indicated on a fivepoint rating scale. ${ }^{2}$ For example, the group was given the statement, "Group leadership was dominated by one particular leadership style." They were instructed to indicate one of the following: strongly agree, agree, don't know, disagree, strongly disagree. The responses scored on each statement were then totalled and compared.

Questionnaire evaluation and analysis

The result of this Likert-type evaluation of responses from the questionnaires administered was overwhelmingly positive as a whole. This corresponded favorably with the verbal and nonverbal responses from the members of the group. The two or three who were

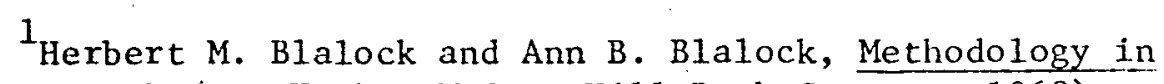
Social Research (New York: McGraw-Hil1 Book Company, 1968), pp. 94-97.

2 Ibid. 
somewhat dubious at the beginning of the course were now enthusiastic along with the others at the prospect of applying these principles of group dynamics in their churches.

Notwithstanding this overall positive result indicated by the questionnaires, however, the distribution of responses to some individual questions in certain categories reveals that there were certain areas of weakness in my methodology. In table 1 for example, the distribution of responses to questions 1 and 3 implies one of three possibilities: (1) the intent of the question was not understood by all the subjects, (2) that these particular guidelines for group process were not grasped by all the subjects, and (3) that all the subjects were not convinced that the writer as a group leader exemplified these particular concepts in the group process. In any case it is a reflection on the teacher and/or his methodology.

The overal1 responses to the questionnaire regarding group relationship, process, and goals indicate the positive impression of the subjects concerning the group process, which in itself is presumably an indication that the group process was healthy, dynamic, and progressive.

The responses to questions 1 through 8,11 , and 12 coincide with what would be normally expected of a properly conducted group according to the established guidelines of group dynamics. However, responses to questions 9 and 10 may be interpreted as a definite reflection of pedagogical weaknesses on the part of the teacher who was modeling as a group leader. The scores for these two questions are contradictory and mutually exclusive. These conflicting scores can only be explained by one or the other of two possibilities: 
TABLE 1

EVALUATION OF GROUP LEADERSHIP, PROCESSES, AND GOALS

Statements
Strongly Agree Disagree Agree
Strongly

Disagree

1. The group was not dominated by any particular leadership style

3

2

4

2

2. Due attention was paid to the needs and interest of the group members throughout the sessions

7

4

0

0

3. Group discussion was kept at a safe theoretical and philosophical level

1

6

2

2

4. Group discussion developed into formal lectures which created a sustained preaching atmosphere more often than not

1

2

1

7

5. Group members were always free to take turns in leading the discussion

2

9

0

0

6. Group members were allowed

free reins for personal

sharing that involved

depth levels

4

7

0

0

7. Certain members were allowed to lead the discussion on a high level of sophistication and intellectual content

0

0

3

8

8. Group members were encouraged to participate at all times

4

0

0

9. Group nembers were encouraged to exprdss freely any feeling of hostility they had towards each other or the leader

1

3

2

5

10. Group interaction was sufficiently significant to develop meaningful relationship that make for personal growth and spiritual maturity of the group 
(1) the teacher failed in his efforts to have clarified sufficiently the matter of "group stages" and its effect on the group-leaderrelationship; or (2) in their elation and satisfaction resulting from the high degree of cohesion attained in the final stage, i.e., "interdependence," the "independent stage" was totally erased from the memory of the subjects.

The responses shown in table 2 reveal the need to be more explicit and emphatic in the clarification of the term "group stages" and its effect on the group process where relationship between the group and its leader is concerned.

The aggregate of the positive scores in table 3 points toward a high degree of success in reaching the teaching objectives and goals of the group leader. This is especially noticeable in the unanimous responses scored by questions $2,5,7$, and 10 respectively. However, the responses to questions 6 and 9 indicate the fact that the leader's performance in modeling group skills and leadership techniques failed to score the 100 percent mark among the group. This is another indication of ample room for improvement in modeling techniques on the part of the group leader.

The spread of responses elicited by question $I$ in this table was not surprising to me inasmuch as this is due undoubtedly to the classroom atmosphere which could not be wholly eliminated and other circumstances imposed by the very nature of the course. This seems readily understandable.

The scores in table 4, focusing on the evaluation of leadership qualities in general exhibited by the group leader in conducting the course, totalled sufficient numbers of positive responses to tip 
TABLE 2

EVALUATION OF GROUP RELATIONSHIP, PROCESS, AND GOALS

\begin{tabular}{|c|c|c|c|c|c|c|c|}
\hline & Questions & & & Respons & ses & & \\
\hline 1 & $\begin{array}{l}\text { Was the group function- } \\
\text { ing marked by objec- } \\
\text { tivity? }\end{array}$ & Always & $(8)$ & Usually & (3) & Seldom & (0) \\
\hline 2 & $\begin{array}{l}\text { Was the group communica- } \\
\text { tion marked by freedom } \\
\text { and spontanity? }\end{array}$ & Always & $(8)$ & Usual1y & $(2)$ & Seldom & (1) \\
\hline 3 & $\begin{array}{l}\text { Was responsibility for } \\
\text { the group process will- } \\
\text { ingly accepted by mem- } \\
\text { bers }\end{array}$ & Yes & (1i) & No & $(0)$ & Don't Know & $(0)$ \\
\hline 4 & $\begin{array}{l}\text { Could the group be } \\
\text { described as being very } \\
\text { cohesive? }\end{array}$ & Always & $(6)$ & Usua11y & (5) & Seldom & (0) \\
\hline 5 & $\begin{array}{l}\text { Was the group open to } \\
\text { information? }\end{array}$ & Yes & (3) & No & (3) & Don't know & $(0)$ \\
\hline 6 & $\begin{array}{l}\text { Were the sessions } \\
\text { boring and tedious? }\end{array}$ & Always & $(0)$ & Usually & $(0)$ & Seldom & (11) \\
\hline 7 & $\begin{array}{l}\text { Would you describe the } \\
\text { group climate as warm } \\
\text { and relaxed? }\end{array}$ & Always & (9) & Usually & (2) & Seldom & $(0)$ \\
\hline 8 & $\begin{array}{l}\text { Was the group willing. } \\
\text { to make its own self. } \\
\text { assessment? }\end{array}$ & Yes & (9) & No & $(2)$ & Ion't know & (0) \\
\hline 9. & $\begin{array}{l}\text { Was the group attitude } \\
\text { always favorable toward } \\
\text { the leader? }\end{array}$ & Yes & $(11)$ & No & $(0)$ & Don't know & $(0)$ \\
\hline 10 & $\begin{array}{l}\text { Would you say the group } \\
\text { experienced the typical } \\
\text { "group stages"? }\end{array}$ & Yes & $(11)$ & No & $(0)$ & Don't know & $(0)$ \\
\hline 11. & $\begin{array}{l}\text { Was the ability of the } \\
\text { group to understand and } \\
\text { respond to the feeling of } \\
\text { one another significantly } \\
\text { improved? }\end{array}$ & Yes & $(11)$ & No & $(0)$ & Don't Know & $(0)$ \\
\hline 12 . & $\begin{array}{l}\text { Have the insights gained } \\
\text { stimulate any creative } \\
\text { action by group members } \\
\text { collectively or indi- } \\
\text { vidually? }\end{array}$ & Yes & (9) & No & $(0)$ & Don't Know & $(2)$ \\
\hline
\end{tabular}


TABLE 3

EVALUATION OF GROUP RELATIONSHIP, PROCESSES, AND GOALS

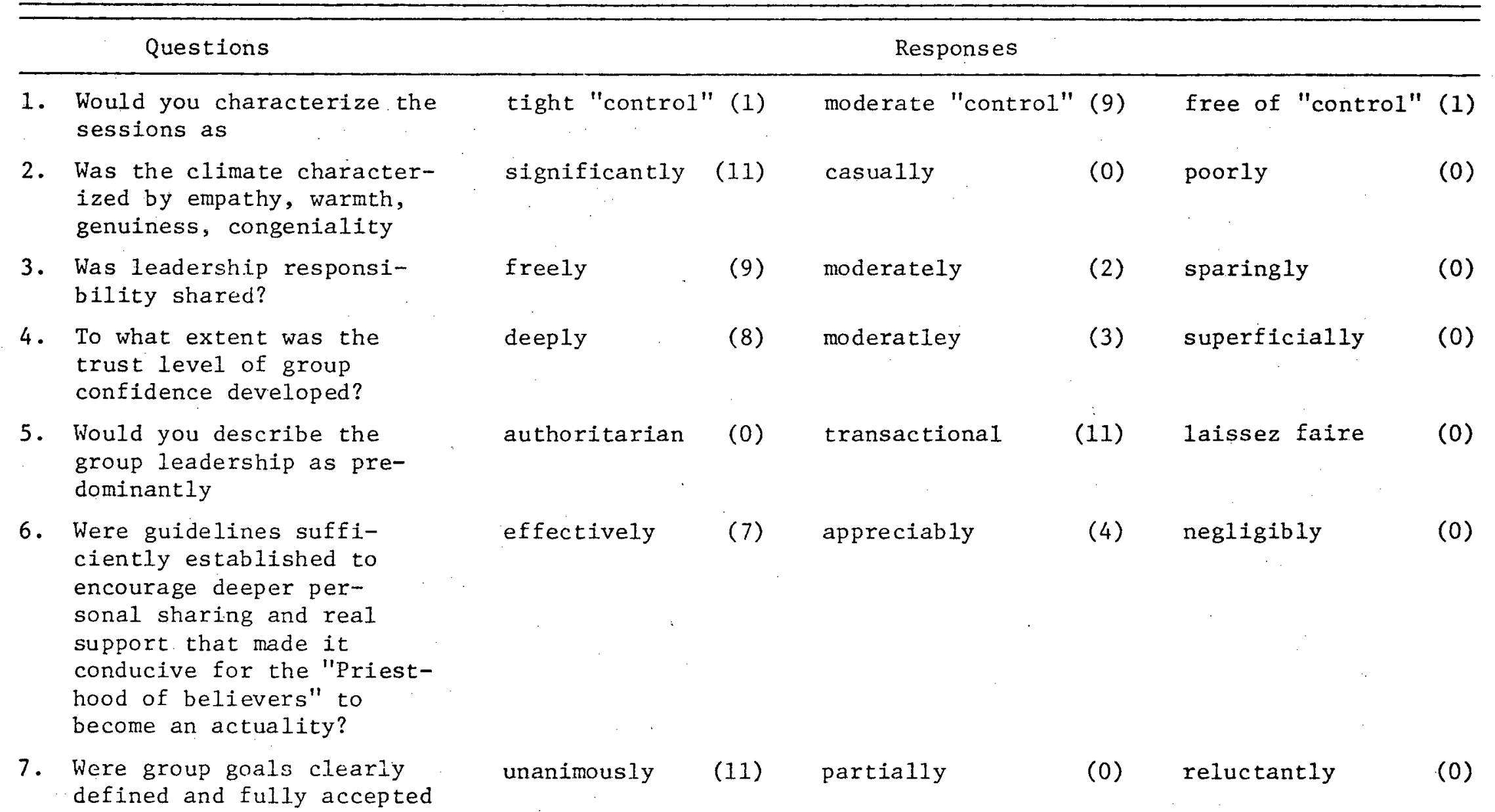


TABLE 3--Continued

\begin{tabular}{|c|c|c|c|c|c|c|c|}
\hline \multicolumn{2}{|r|}{ Questions } & \multicolumn{6}{|c|}{ Responses } \\
\hline 8. & $\begin{array}{l}\text { How well were you satis- } \\
\text { fied with the tempo of } \\
\text { the group action? }\end{array}$ & completely & $(10)$ & partial1y & (1) & none at all & $(0)$ \\
\hline 9. & $\begin{array}{l}\text { In your opinion did the } \\
\text { leader set the pace in } \\
\text { openness, in sharing, in } \\
\text { honesty, in committment, in } \\
\text { dedication to Christ and the } \\
\text { group? }\end{array}$ & excellent & $(8)$ & good & (3) & poor & $(0)$ \\
\hline 10. & $\begin{array}{l}\text { As a result of this semi- } \\
\text { marathon group session, have } \\
\text { you experienced personal } \\
\text { growth in interpersonal } \\
\text { relationship and grasped the } \\
\text { concept of the small group } \\
\text { dynamics sufficiently to make } \\
\text { uou feel that you would like } \\
\text { to conduct for your church } \\
\text { elders a similar program? }\end{array}$ & $\begin{array}{l}\text { as soon as } \\
\text { possible }\end{array}$ & (11) & next year & $(0)$ & $\begin{array}{l}\text { in the distant } \\
\text { future }\end{array}$ & $(0)$ \\
\hline
\end{tabular}


TABLE 4

GENERAL EVALUATION OF THE GROUP LEADER

\begin{tabular}{|c|c|c|c|c|c|c|c|c|}
\hline & Statements & $\begin{array}{l}\text { Very } \\
\text { Charac- } \\
\text { teristic }\end{array}$ & $\begin{array}{l}\text { Charac- } \\
\text { teristic. }\end{array}$ & $\begin{array}{l}\text { Slightly } \\
\text { Charac- } \\
\text { teristic. }\end{array}$ & $\begin{array}{l}\text { Don't Know } \\
\text { Undecided }\end{array}$ & $\begin{array}{l}\text { Slightly } \\
\text { Uncharac- } \\
\text { teristic }\end{array}$ & $\begin{array}{l}\text { Uncharac- } \\
\text { teristic }\end{array}$ & $\begin{array}{l}\text { Very } \\
\text { Uncharac- } \\
\text { teristic }\end{array}$ \\
\hline 1. & $\begin{array}{l}\text { Fails to identify with the } \\
\text { group }\end{array}$ & 0 & 0 & 0 & 0 & 0 & 3 & 8 \\
\hline 2. & $\begin{array}{l}\text { Suggests direction about how } \\
\text { to proceed }\end{array}$ & 5 & 6 & 0 & 0 & 0 & 0 & 0 \\
\hline 3 . & Seeks attention to himself & 0 & 3 & 1 & 2 & 1 & 4 & 0 \\
\hline 4 . & $\begin{array}{l}\text { Seeks to rights of others } \\
\text { in the group }\end{array}$ & 8 & 2 & 0 & 1 & 0 & 0 & 0 \\
\hline 5. & $\begin{array}{l}\text { Tries to keep the group on } \\
\text { course }\end{array}$ & 7 & 4 & 0 & 0 & 0 & 0 & 0 \\
\hline 6. & Holds to his point regardless & 0 & 0 & 0 & 0 & 0 & 1 & 10 \\
\hline 7. & $\begin{array}{l}\text { Always ready to give an } \\
\text { understanding ear }\end{array}$ & 9 & 2 & 0 & 0 & 0 & 0 & 0 \\
\hline 8. & $\begin{array}{l}\text { Help to build a good team } \\
\text { spirit }\end{array}$ & 9 & 2 & 0 & 0 & 0 & 0 & 0 \\
\hline 9. & $\begin{array}{l}\text { Frequently blocks the group } \\
\text { process }\end{array}$ & 0 & 2 & 0 & 0 & 2 & 1 & 6 \\
\hline 10. & A ready helper & 3 & 8 & 0 & 0 & 0 & 0 & 0 \\
\hline 11. & Inconsiderate of others & 0 & 0 & 0 & 0 & 0 & 2 & 9 \\
\hline 12. & Solicit support of others & 1 & 6 & 2 & 0 & 0 & 2 & 0 \\
\hline
\end{tabular}


TABLE 4--Continued

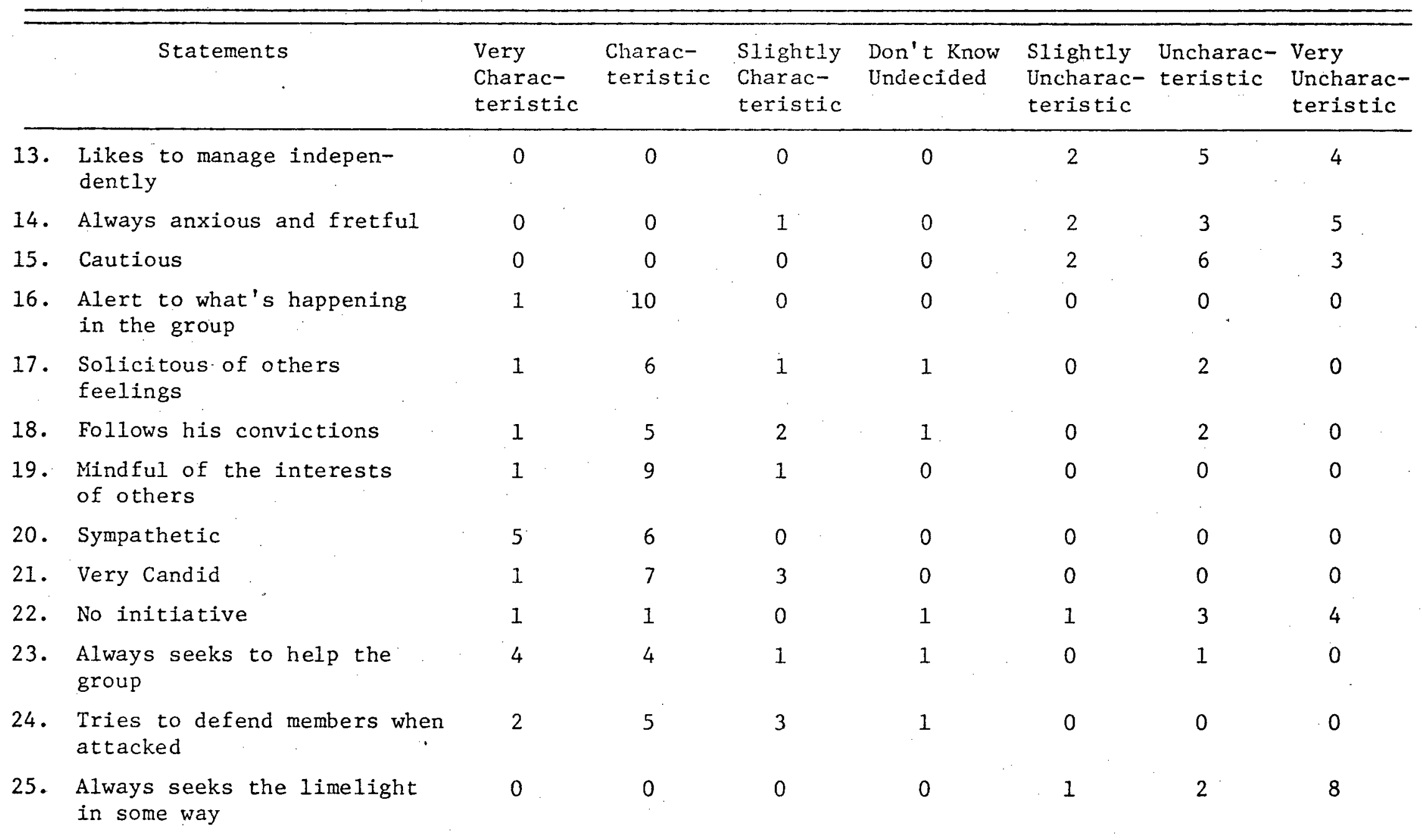


TABLE 4--Continued

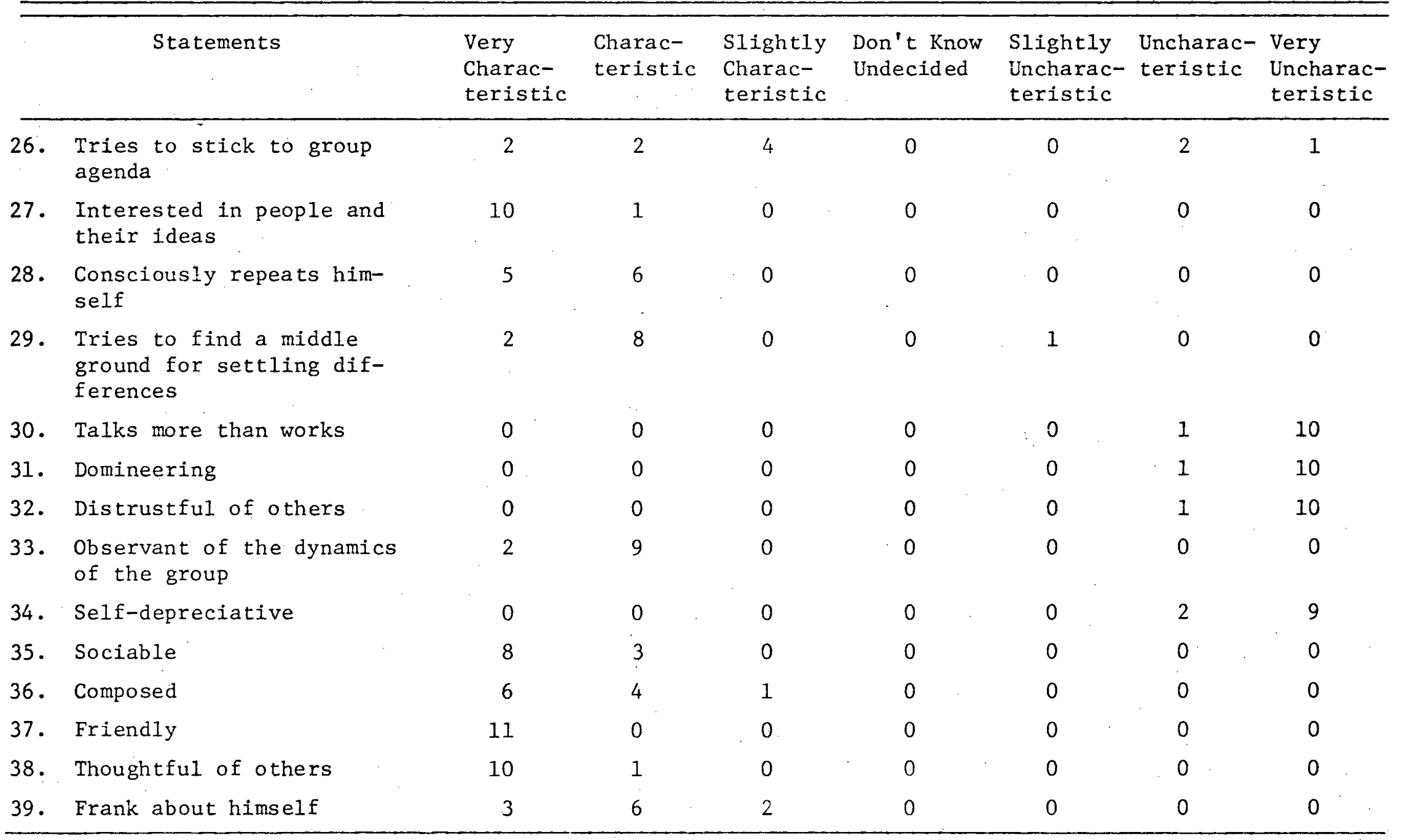


the scale by any standard of measurement in favor of the group leader and teacher. It must be noted, however, that upon closer analysis of the individual responses to each question certain areas of apparent weaknesses are readily obvious. For example, the spread of responses to questions 3 and 17 seems to indicate some degree of correlation inversely which would give further support to the authenticity of the implication inferred by these responses, namely, that the leader did not demonstrate sufficiently that quality of absolute unselfishness demanded by his position to the satisfaction of the entire group membership. This revelation served as an eye opener and contributes to a keener sense for the need of roledistancing on my part.

The last questionnaire (see table 5) was designed to evaluate more specifically the measure of progress achieved toward group goals. The results are very revealing; for example, a cursory glance at the table shows a favorable picture of positive responses. A total of 18 out of 27 of these Likert-type questions scored full marks, i.e., a positive response from the entire group of eleven subjects. Of the remaining nine, seven obtained 10 positive responses out of the possible 11 and the other two scored 7 out of the 11. On the whole the result of the feedback on this questionnaire appears to be positive.

At the same time, however, I am keenly aware of the fact that the negative responses, stand out as a constant reminder that the ultimate is yet to be achieved. While it is true that these statistics reveal an overall positive picture in the achievement of group goals it must be conceded that they also indicate the fact that 
TABLE 5

EVALUATION OF GROUP PROCESS AND GOALS

Statements

1. I have gained a better understanding and appreciation

$\begin{array}{lll}11 & 0 & 0\end{array}$ for others in our group

2. I enjoyed the freedom of self-expression in the group

$\begin{array}{lll}11 & 0 & 0\end{array}$

3. I believe others in the group expressed themselves

$\begin{array}{lll}10 & 0 & 1\end{array}$

freely and sincerely and letting me come to know them in a meaningful way

4. I believe all in the group came to know each other

10. 01

5. I have confidence in all members of the group

6. I believe that I am understood by, and share the confidence of the members of the group

$\begin{array}{lll}11 & 0 & 0\end{array}$

7. I believe I have been completely accepted by the group $11 \quad 0 \quad 0$

8. I have no difficulty expressing appreciation of mem- $\begin{array}{lllll}11 & 0 & 0\end{array}$ bers in the group

9. I believe other group members really love and appreci- 1100 ate me

10. I let other members of the group know that I really $\begin{array}{llll}10 & 0 & 1\end{array}$ care about and I am praying for him

11. Other members of the group told me that they care about $7 \quad 0 \quad 4$ and are praying for me

12. I have learned some things in the word of God that I 1100 did not understand before

13. As a result of this approach to Bible study certain portions of the word of God have become more meaningful to me

14. Al1 members of the group contributed to a better

1100 understanding of Bible passages and their personal applications

15. I think the Bible was given its rightful place in the group

16. I persona1ly enjoyed this method and approach to Bible study

17. I believe that the presence of Christ through the Holy Spirit was with the group all the way

1100

18. We have learned to share in a meaningful way what the
Lord has done and is doing in our lives

18. We have learned to share in a meaningful
Lord has done and is doing in our lives

$\begin{array}{lll}10 & 0 & 1\end{array}$

$10 \quad 0 \cdot 1$

$\begin{array}{lll}11 & 0 & 0\end{array}$

1100 
TABLE 5--Continued

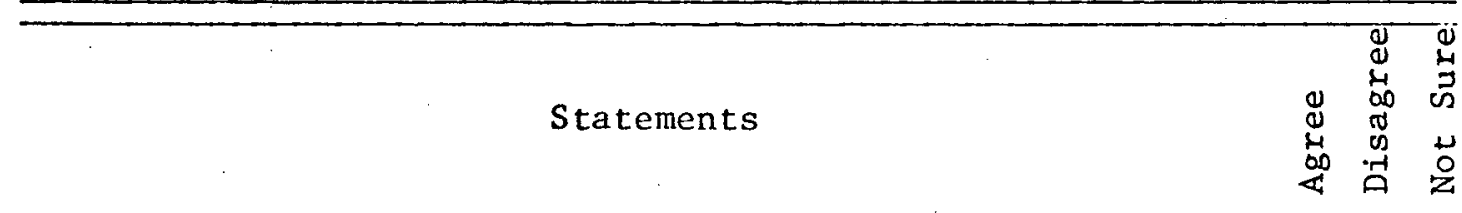

19. I have been drawn closer to Christ Jesus to group experience

1100

20. I believe other members of the group have also shared $\begin{array}{lllll}11 & 0 & 0\end{array}$ this experience

21. This group experience helped to make the love of. Christ more meaningful to me personally

22. There was a real sense of worship and praise as we studied the word of God and shared together our experiences

23. The worship dimension built in to all our group gatherings was appreciated by a11 group members

24. Members were encouraged to express their feeling of praise or prayer as opportunity afforded

25. Members were drawn into closer relationship with Christ and with one another

26. I believe others worship God in ways that are pleasing to Him when we meet

27. This group experience has helped me to appreciate the efforts of others to worship God

1100

28. Describe the group climate in one word*

29. Suggestions (given in text)

*Warm (1), Excellent (2), Satisfying (2), Healthy (1), Fellowship (1), Cordial (1)

perfection in the attainment of every individual group member's goals eluded us.

As already noted, the questionnaires viewed whollistically, point to a positive overall effect. This was clearly reflected in the changed attitude of the students (ministers). Some have written letters of appreciation since their return to the field, and one minister in particular reported that already there were encouraging 
signs of spiritual revitalization in a church where he introduced group methods. Samples of responses from an open-ended question relative to the personal evaluation of the course appear below. The question to which responses were written was "What suggestions or impressions do you have concerning the course?":

(1) "The interest and power for good that this course is capable of engendering, I am sorry that a longer time could not be designated to its running."

"I" strongly suggest that a program like this should be given recognition from a General Conference level. If this becomes a reality I see no difficulty why it should not be accepted on all the levels of our organization."

(2) "The course is well conducted; from it my horizon is widened. The methodology is very good and I cannot conceive of a ketter way that the lectures could be presented so that a group could be benefitted as it is today. My prayers go with you, J. C. May God bless you."

(3) "That the leader returns to W. I. C. and conduct similar sessions as early as possible."

(4) "I suggest that this course be taught here at West Indies College and that this course be carried on in the nearby churches."

(5) "That this program be presented in a much broader scale in order to incorporate much more of the leadership of the church."

(6) "Please continue to be the good leader you are, E1der Palmer. You did a good job in the group relationship we had over 
the past two weeks. I believe you did your very best to help us to become good leaders, and to develop that kind of communication which is so badly needed in our world today."

(7) "I am convinced that the meetings were good. We needed (1) more discussions; (2) more time for fellowship; and (3) more time for role-playing."

(8) "This type of leadership should be shared with much more of our leaders."

(9) "Koinonia groups offer the solution to the many hungry souls who lack identity in the church today. The concepts and practice of the koinonia group should be encouraged as early and as widely as possible."

(10) "The course was a very good one; it needs to be taught in al1 the colleges."

(11) "That this course be made a core subject for all pastors in the Seventh-day Adventist ministry."

"I sincerely pray that the principles as taught in this course may be truly adopted organizationally and implemented throughout our world field, whether it be through similar workshops or otherwise. I enjoyed the course immensely."

In summary, according to my interpretation of the results of the instruments used, there were certain areas of weaknesses in my methodology, both as teacher and as group leader. In the role of a teacher the mosi pronounced area of weakness was the tendency to cram too much material into one session in an effort to cover the syllabus within the time schedule. This resulted in curtailing discussions. In the role of a group leader this weakness surfaced in the form of 
a slight tilt towards a task-oriented stance.

The experience of this project has taught me to aim at a more equitable balancing between the task-oriented and the maintenance functions of the group process.

\section{Implications}

For the church

The success of the project coupled with the enthusiastic responses of the participants confirm the writer's convictions that (1) the small group structure for developing and deepening koinonia provides in some measure at least the solution to the problem of the attrition of new converts, and (2) the small group process offers significant potential for tapping the largest single resource of the church, the laity.

As a result of this project, therefore, the following observations seem pertinent:

(1) The potential of the small group process to effect behavioral change has been very clearly demonstrated by the project as reflected in the changed attitude on the part of the subjects. It would appear that the church can face successfully the challenge of making use of the insights coming from the field of group psychology and other creative branches of social science today. ${ }^{1}$

(2) The spirit of genuine caring and concern that group members developed for one another was suggestive of the description

$1_{11}$ is for a lack of utilizing the rich harvest of research in the dynamics of group experience even before Christian grace had its opportunity for witness that many experiments in interpersonal fellowship in our churches have foundered." Castee1, p. 50. 
of the group spirit characteristic of the New Testament Church. This implies that what the church needs today is a rediscovery of this small group dynamism which made the early church into one great cohesive force bound together by this "soul fellowship" ${ }^{1}$ and a mutual member-to-member ministry.

(3) It demonstrated that it is possible for the church today to rediscover this spirit that marked the pioneers of the Seventhday Adventist Church in its infancy--a rediscovery of the genius of the small group to establish that genuine "brotherhood of love and fellowship" which united the pioneers in their struggle for spiritual identity, and gave the infant church a forward thrust that nothing could daunt.

(4) The genuine brotherly love and concern developed in the group clearly shows that the church through this group method can begin to surmount the barriers of self-interest and indifference and attain the desirable state of a truly caring fellowship among its professed adherents. Thus, many who are now looking on will believe the message of the Savior's reconciling love:

The Christian faith speaks of love and reconciliation. Millions are longing to believe in them, but until they find them actually making a visible difference in lives like their own in a church, they cannot believe. In a world of gulfs and estrangements, people need to be members one of another, but many doubt this is possible. Until they experience this in a Christian church, they find the idea hard to accept. 2

(5) This project also demonstrates that the small sharing group or spiritual growth group under properly trained leadership

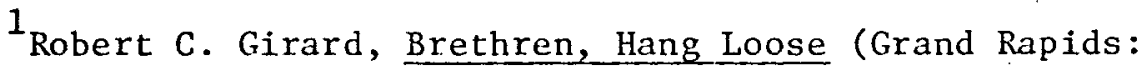

Zondervan Corporation, 1972), p. 95.

${ }^{2}$ Handy, p. 55. 
offers a good opportunity for meeting the challenge of developing realkoinonia despite the size of the church. Inasmuch as it is impractical for the church to develop this meaningful relationship en masse, sharing groups, or spiritual growth groups, constitute the most logical structure for this purpose. It is only in such a setting that individuals can create as well as participate in a loving community that cares far beyond any they have known before when given the opportunity and the leadership.

(6) It was also shown that small face to face groups wlich meet over weekends or for any extended period of time can get past the superficiality and emptiness of so much of what they have experienced before in churches to relationships that have depth, meaning and concern. 1

In the authoritative writings of the church we find definite counsel encouraging a structure of this sort, where people sould be free to interact in groups sharing their experiences and building "loving acquaintance":

Let small companies assemble in the evening, at noon, or in the early morning, to study the Bible. Let them have a season of prayer, that they may be strengthened, enlightened, and sanctified by the Holy Spirit. Angels of God will be-in your assembly. . . What testimonies you may bear of the loving acquaintance made with your fellow-workers in these precious seasons when seeking the blessings of God. Let each tell his experience in simple words. . ." 2

If we accept the Seventh-day Adventist understanding of Biblical eschatology and believe that we are living in the "end-time"

${ }^{1}$ Philip Anderson and Phoebe Anderson, pp. 7, 8.

${ }^{2}$ White, Testimonies to the Church, 7:195. 
period of earth's history, then this counsel is particularly timely and relevant. It is well to note that it becomes even more urgent in these closing days of earth's history: "There will be less preaching and more Bible study. There will be little groups... with their Bibles in their hands, and different ones leading out in a free, conversational study of the Scriptures." 1

(7) This project also points to the possibility that, by providing special opportunity for group interaction (utilizing and improving basic communication skills) and encouraging relational Bible study and sharing, the small group method may facilitate the building and deepening of koinonia among old and new members alike. This binding fellowship develops the sense of oneness, a feeling of togetherness, thus bringing to the consciousness of the new believer the feeling that he is loved and wanted; he is an important member of the church family; he is accepted in the ownership of the church--the family estate. ${ }^{2}$ Consequently, he develops a sense of belonging. The interests of the church now become his interests.

(8) This quality of fellowship demonstrated by the group in the project also implies that similar group interaction (spiritual. growth groups in the church) can stimulate and enhance genuine caring

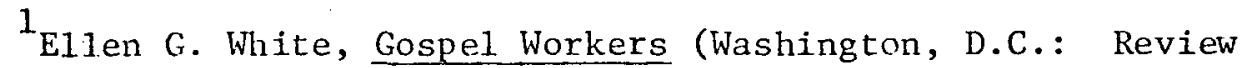
and Herald Pub. Assn., 1946), pp. 407-8.

2 "A convert needs special support during the first months of enlistment in his new life in the church. . . . The strength of several concerned persons is of great value to one just beginning a totally new way of life. Assimilation into the church is easier when one moves from the small group fellowship than when he tries to start out completely alone. People can learn the elementary lessons of caring in the warmth of a small group." Barlow, p. 24. 
in the biblical sense of "bearing one another's burden;" ${ }^{1}$ thus encouraging a conscious and systematic effort in promoting a mutual member-to-member ministry that could rapidly envelope the entire church and equip her for real effective ministry to the world.

In short, this project suggests possibilities of harnessing the entire church through group processes for the capturing of the spirit of Christian love and concern for one another and the zeal and burden for the souls of our fellowmen, that characterized the early church. With this kind of involvement, the spiritual resurgence that will culminate in the fulfillment of Pentecost would soon be realized.

Indeed, it is only as the church rediscovers this latent power waiting to be released through the dynamics of the small group interaction, can she recapture that vibrant, aggressive spiritual force that distinguished the early church as going forth "conquering and to conquer." It is in this spirit that the church will accomp1ish her mission to the world. It is in this spirit that the gospel commission will finally be accomplished. 2

Fina11y, Christ will see that for which He has been long waiting to fulfill His promised return--the reflection of His character in His people; ${ }^{3}$ His spirit of love, acceptance, forgiveness, oneness. He will be satisfied that it is safe to take them to His home of bliss for they have overcome all tendencies towards

$1_{\mathrm{Ga} 1} 6: 2$.

2Wite, Testimonies for the Church, $6: 64$.

3 Russel Holt, "What On Earth Is Jesus Waiting For?" These Times, July 1975, p. 7 . 
divisions, dissensions, class distinctions, rejection and alienation; all coldness and aloofness; a11 distrust and doubts; yes, all critical and judgmental attitudes are now lost in koinonia. Christ's. love now cements their relationship and heaven's harmony now reigns in the church. Christ will then come to take her to reign with Him in the splendor of His effulgent glory.

For the writer

The implications from the project for the writer are are as follows:

(1) Improvement of skills as facilitator in the role of group leadership

(2) Improvement of communication skills

(3) The opportunity to apply new concepts and practice new leadership techniques learned from the courses in Group Dynamics and other courses in leadership skills at Andrews University; thus contributing significantly towards leadership growth and maturity

(4) The opportunity of developing koinonia deepened the sense of caring and sensitivity to the personhood of human beings

(5) The establishment of confidence in the fact that a proper grasp and practice of the koinonia concept can make a definite contribution to church revitalization and prepare the way for the outpouring of the "latter rain." 1

${ }^{1}$ See Acts $2: 1-4$; White, Acts of the Apost1es, pp. 50, 51. 


\section{Conclusion}

The success of the project in terms of the goals of the writer, establishes the fact that the concept of koinonia for the development of meaningful relationships in the church is not only workable, but desirable. This was further reinforced by the unanimous responses of the participants as well as by outstanding church leaders who participated in the sessions.

This strong band of "Christ-fellowship" (koinonia) that developed among the participants in this group experience, the keen sense of caring and concern, also demonstrate the validity fo the prospects of koinonia to bind and cement new believers in the church family. This will have the effect of stabilizing new converts, thus consolidating our annual evangelistic gains and reducing the attrition rate.

Another aspect of the project that argues well for similar effort in the future was the expressions of gratitude from the participants for the new concepts and the modern approach to leadership. This was most gratifying and encouraging to the writer because if this group of pastors, drawn from all over the West Indian terriotry, should be taken as a sample, it indicates that the pastors in this territory are quick to grasp and utilize new concepts that will prove beneficial to their churches, and new leaderships skills that will contribute to the effectiveness of their leadership in their respective fields. 


\section{Recommendations}

As a result of the conclusions drawn from the demonstration of this project the writer feels free to recommend:

(1) That the West Indies Union Conference of Seventh-day Adventists follow through their endorsement of this particular program, "Operation Koinonia," by providing the opportunity and support necessary for its official adoption by the Ministerial Department of the Union Conference.

(2) That the ministerial department of the union conference urge its adoption by the ministerial departments of the local conference.

(3) That the ministerial department of the union conference publish at least one article each month in connection with "Operation Koinonia" in its monthly periodical, The Visitor, for a stated reriod. This will create in the field a public awareness of the spiritual impact of this program.

(4) That the union conference ministerial department in cooperation with the local conferences.' ministerial departments make definite plans for a series of ministerial institutes, seminars or workshops in "operation Koinonia" to be conducted throughout each local field.

(5) That study be given by the theological department of West Indies College to the feasability of incorporating this course, or a modified form of it, under the course title, "Introduction to Group Dynamics," into its curriculum as a core subject. (The writer's twenty-five years' experience as pastor, evangelist, administrator, can attest to the fact that many board meetings, 
church business meetings would have been much more productive and spiritually satisfying if the participants were aware of certain dynamics of the group, and if the leaders possessed certain necessary group skills to create proper group climate. Surely this knowledge is no longer optional for the pastor. It is an absolute essential.

(6) That in view of the potential benefits for improving human relationships the West Indies Union Conference give study to the feasability of conducting a "Human Relationship Workshop" for its staff under the auspices of its ministerial department.

(7) That the union conference recommend to the leaders of the local fields and institutions a similar workshop. 
APPENDIX A

SAMPIE OF A TYPICAL CLASS IECTURE 


\section{FUNDAMENTAL PRINCIPLES UNDERLYING SMALL GROUP PROCEDURES}

The following is a sample of a typical class lecture, based on the instructional material used in the course. The lecture notes, for all lectures, were considered too voluminous to be submitted for exhibition.

\section{A. Self-Actualization}

Man's highest need is a desire for self-actualization. Johnson and Johnson in their book, Joining. Together, pp. $289 \mathrm{ff.}$, suggest that the advocates of growth groups tend to make the assumption that people have self-actualization or self-realization as their end goal in life through their self awareness and intentionality. "Self-actualization may be defined as the psychological need for growth, development and utilization of potential."

Self-actualization involves self-development as well as selfutilization--the potentials which are developed are used to actualize oneself. A self-actualizing person, then, moves towards the full use of his talents, capacities and potentialities. The goal of self-actualization in growth groups is to have greater personal understanding and awareness, and an increased sensitivity to the surrounding environment and to other people.

A. H. Maslow and other behavioural scientists suggest the key to the explanation of human motivation which is arranged in sequential order of hasic needs. Some needs take priority over others. This corresponds to what Oman calls, in the Freudian language, the id. This embodies all organic, instinctual, selfish desires, impulses and motives. "The goals of the id are basically to keep the body nourished, warmed, cooled, free 
from pain and puxringly content." (See his book, Group Counseling in the Church, pp. 49ff., and notice how he develops this concept.)

So according to this theory, the concept of hierarchial needs would look something like this: (here, I illustrated on the blackboard the needs arranged in the form of a ladder, with the following comments).

(1) Security needs -- We want to be secure, to have a predictable and organized life. As an illustration of security or safety needs: a desperately thirsty person is not very concemed about the purity of the water; a starving person is not so concerned about germs or sanitation as much as to get food in his stomach.

(2) Social needs -- When the need for security is filled, the social needs begin to dominate. One of our most compelling needs is to associate with others of our kind. Homo sapiens are very social creatures; the lack of comingling with other human beings introduces loneliness.

(3) Status and Esteem needs (ego) -- As soon as associational needs are met in our achievement of a place within a group we begin the longing for esteem. Behavioural scientists emphasize that we need prestige, and that closely associated with this need for prestige is the desire for esteem. There are two sides to this motive--public and private. The public side is reflected in our need to be highly regarded by others. The private side is revealed in our need to like ourselves. We want to have self-confidence, to have a good self-image and a feeling that we are really important. This corresponds to the ego. The ego comprises the conscious feelings, desires and thoughts. "The deficit ladder includes only the selfish needs--needs closely related to preserving our individual self and gratifying our ego." 
(4) Self-actualization needs -- When all other levels of needs have been satisfied the last and highest level comes to the front. Selfactualization becomes the goal for those who have achieved a strong feeling of selfworth. This corresponds to the super ego. The individual feels loved and esteemed and has that warm inner feeling of being valuable and worthwhile--worthy of love and esteem. Now he turns his attention to creative lines of activity which he finds satisfaction in doing. Fromm points out that the correct person who loves him or herself will indeed love others and will feel a great sense of responsibility for society (Gardner, p. 5).

According to Oman's book, Group Counseling in the Church, pp. 50ff., it is this super ego that gives perspective to life; it gives the third dimension to life, supplying the motivating power that drives man to the highest achievement. This is where growth groups come in, for growth groups seek to provide this opportunity for the individual to transcend the self, (that is the id) and find a larger meaning in life, as people seek self-fulfilment through the development and utilization of their potentials. (At this point questions and discussion were entertained before moving into the next section dealing with "group dynamics.")

\section{B. Group Dynamics}

In the most basic sense, the term "group dynamics" is used to describe something that is happening in all groups at all times, whether anyone is aware of it or not.

Group dynamics, therefore, can be either static or dynamic.

Static. The term "static" refers to the name of the group or organization, constitutional structure, ultimate purpose and other fixed 
characteristics.

Dynamic. The term "dynamic" refers to action, movement, changing, becoming, acting, interacting and reactirig in the group.

The interaction of these forces with their resultant effects constitute the dynamics of the group. There are always forces from within as well as from without the group that influence dynamics. Group dynamics is to the group what personality is to individuals; it is a phenomenon that occurs naturally--nobody invents it, nobody can prevent it.

Other Uses of the Term -- There are other uses of the term, however, of which we should also be aware:

(1) A Field of Study: Group dynamics is also used to describe a field of study--a branch of the Social Sciences concemed with using scientific methods to determine why groups behave the way they do.

(2) Body of Knowledge: Another use of the term "Group Dynamics" according to MaIcolm and Hulda Knowles, is in reference to the body of basic knowledge about group behaviour that has accumulated from past research.

(3) Field of Inquiry: Cartwright, Darwin and Zander, 1968, also use the term to refer to a Field of Inquiry dedicated to achieving knowledge about the nature of groups, the laws of their development and their inter-relations with individuals, other groups and larger institutions.

(4) Applied Group Dynamics: This is concemed with the use of knowledge about group processes. Malcolm and Hulda Knowles also use the term "group dynamics" in describing a growing body of applied knowledge, or technology, which attempts to translate the findings and theories of basic knowledge into practical principles and methods. 
To summarize, the study of group dynamics is concerned with phenomena that arise when a collection of individuals has become for whatever reason, sufficiently interdependent to be called a group.

Dimensions of Group -- Let us now consider some dimensions of the group. There are some dimensions of the group processes which help us to understand the forces that work in groups. These are structural dimensions, stages of development and behaviour inodes.

Structural Dimensions -- Let us look for a few moments on what Neely D. Gardner calls structural dimensions. He says that groups work at three levels simultaneously--procedural, substantive and feeling.

(1) Procedural: Groups operate according to certain procedures which may be either consciously determined or derived through happenstance, e.g., people tend to stake out their own physical territory when left to operate in an unplanned way--thit is, they sit in the same seat or the same location at each meeting. They may arrange themselves in open circles or sit around a conference table or on benches.

They may adopt specific communication patterns; for instance, every one may direct his remarks to the leader or chairman, or they may talk around the circle in succession in conversational style. They may talk at one another rather than communicating with one another.

Listening may be a problem in some groups with every one talking and few listening, while it may be a normal pattern for one to speak at a time while the others listen.

Leadership may be proactive and authoritarian in some groups, while in others it may be facilitative or nonexistent.

Some groups may evaluate happenings in their sessions to see whether these forward or inhibit the group efficiency while others do 


\section{5}

not. Some groups may deal with conflict openly and straightforwardly, while others ignore or repress conflict. Some members may choose to be vocal in their groups as to their position on important issues, while others may choose to remain silent. Some groups arrive at their decisions by voting or by consensus, while other groups choose not to decide. Some groups become so enamoured of the group process that they spend too much time looking at feelings, while others are strictly "product oriented" and insist that feelings do not exist. Note here that the group leader must be careful to avoid either extreme.

(2) Substantive: Now let us take a look at the substantive. What does he mean by the term? He says that substantive activity can be used to describe a group's activity when it addresses itself to the stated agenda. This may be working problems, arriving at decisions or leaming what comprises the substantive life of the group. So much for that.

(3) Feelings: What about feelings? People are just beginning to admit that human beings do have feelings and that they are not dishonorable. Many theorists now show the damage one can do to himself by trying to hide or suppress his feelings, and the good that he does to surface, admit and deal with them in a realistic manner.

We may as well admit that we do have feelings and that they influence our behaviour and our relation to others. The behaviour modes and the stages of development will be discussed later on in the course when we come to the topic "Group Behaviour." (Here, opportunity was given for another lively discussion on the section covered.)

So we see that group dynamics is concemed with the study of all the forces within the group that contribute to, or interfere with, the 
group's goal as well as with the best methods that can be employed to improve the effectiveness of the group.

Group Defined -- Now we will turn our attention to some scientific definitions of a group. Groups can be defined as collections of individuals and as such, the understanding of the behaviour of individuals is a prerequisite to the understanding of the behaviour of groups. Researchers, therefore, have been concemed with gaining a better understanding of the causes and dynamics of individual behaviour in groups. Students of group dynamics zero in on the information of individual behaviour from such sources as psychology and psychiatry--that's from Knowles, Introduction to Group Dynamics.

Johnson \& Johnson define a group as "a collection of persons who are in cooperative, face-to-face interaction, each aware of his or her own membership in the group, each aware of the others who belong to the group, and each getting some satisfaction from participating in the group's activities."

Edgar N. Jackson, in his book, Group Counseling, Dynamic Possibilities of Small Groups, p. 17, says that sociologists define a group as a number of persons who, for a period of time, lend their common efforts toward a common goal, e.g., the Senate, Congress, family, school.

In their definition of small groups Burgoon, Heston and McCroskey point out three significant elements that characterize. a group--" (1) face-to-face (2) interaction of two or more persons in such a way that members are able to (3) recall the characteristics of the other members accurately."

Delineation: Let us take a closer look at those three key terms. 
The first key term is "face-to-face." This means that people must be in proximity to be considered a small group. The second key term is "interaction." To be a small group the members must communicate with one another. The third key phrase is that members are able to "recall the characteristics of the other members accurately." This signifies that the members relate to one another in such a way that they become aware of the existence of a group and their identification with it.

Group Size - Now let us consider group size. Is there any limitation on numbers? Jesus, who was far ahead of the social scientists, as we have seen, on this matter of the group phenomenon, intimated the parameter in Mt 18:20--"For where two or three . . ." and by the number of His immediate disciples. Some authorities recomend from one to twenty, but the consensus is that six to ten is the ideal number.

Rule of Thumb -- Phillips in his book, Communication and the Small Group, pp.41ff., suggests that a safe "rule of thumb" is that, in general, members of the group should be able to speak directly to each other with minimum effort, in order for it to qualify as a small group.

The most effective group is one that is small enough so that members can communicate face to face. Communication becomes more difficult with the increasing size of the group because the level of the voice has to be raised and it is more difficult to look directly at the other members.

Scientific Reasons for Limiting Size -- There are good scientific reasons for limiting group size. Let us look at some of these.

(1) Relationship -- In his book, A Theory of Leadership Effectiveness, Fred Fielder says: "Rarely can more than ten or twelve persons main- 
tain an informal face-to-face relationship for very long. Once the number grows some administrative action becomes inevitable."

(2) Mutual Response Bonds -- Group action is made up in part of interaction between pairs of persons. This interaction between two people is called "mutual response bond" and is illustrated below: (This was illustrated on the blackboard.)

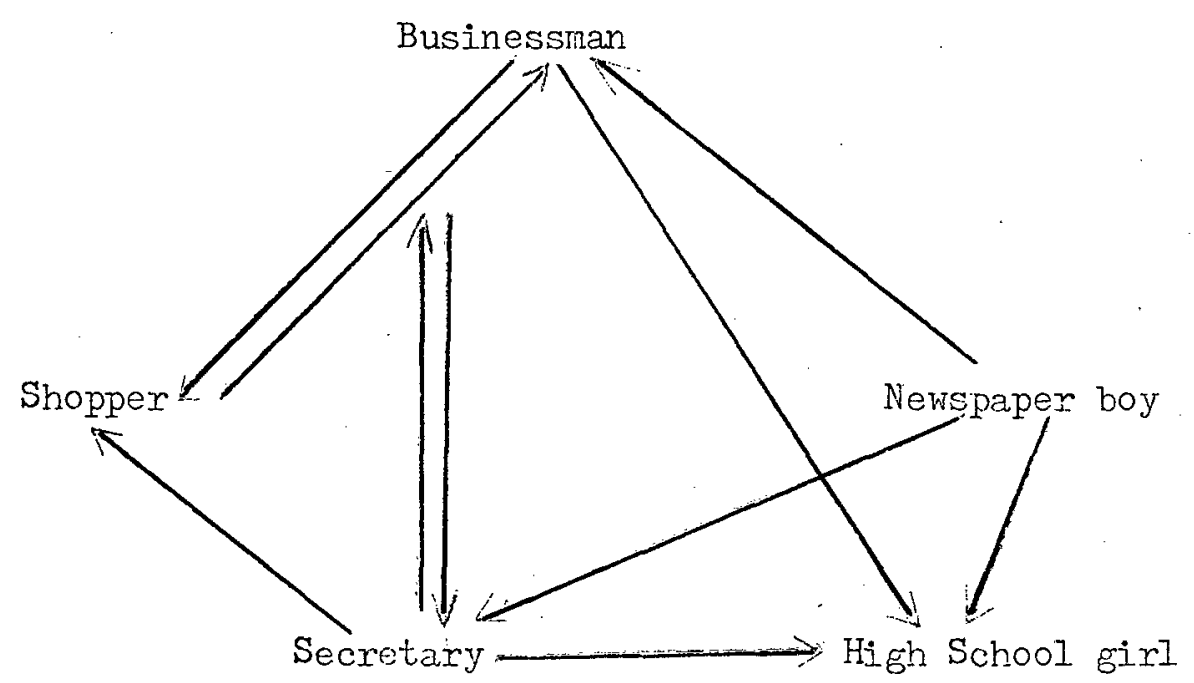

(Arrows represent response bonds as these five people start a conversation while waiting at the subway. $)^{*}$

A group can be considered as a collection of people bound together by a network of mutually acknowledged responses between pairs of persons. This means that each new person added to the group increases the numerical progression or response bonds. Fach time a person is added, the number of potential response bonds is increased by the number of persons present before the addition, hence the formula:

*Adapted from Robert R. Powell, Manasing Church Business Through Group Procedures (New Jersey: Prentice-Hall, Inc., 1964), p. 32. 
The number of persons in a group multiplied by the same number, minus the same number, and divided by two equals the potential number of mutual response bonds. Thus

$$
\frac{N^{2}-N}{2}=B \quad(\text { Powell, p. 34). }
$$

(3) Sense of Belonging -- Group size is not the only factor that makes it difficult to establish potential response bonds. The existence of a bond itself often interfered with the establishment of an additional bond. This is so because a bond serves the psychological purpose of providing a sense of belonging.

(4) Large groups tend to develop sub groups with divergent goals. There is the possibility of cliques or "gang-ups" or fragments. This is the belief of Gerald M. Phillips. Larger groups have more resources, but the role that a member can play is diminished.

(5) Heterogeneity of contribution -- The group size has to be small enough to allow each participant the opportunity to contribute to the interaction of the group, but it must be large enough to allow the participants to space their contribution according to individual needs and capabilities. If a group is too small, each member is constantly on call and if it is too large, there is the tendency for the members to hide in the crows. The group must be of a size to make factors such as heterogeneity of contribution, diversity of opinion, coalition formation and other variables optimally productive in terms of learning. (Again, I paused to take some questions and allowed some interesting discussions.) 


\section{Types of Groups}

We come now to types of groups. These are mainly determined by the behaviour of the individuals within the groups. There are two main categories: interest or growth-oriented group which includes intensive group experience or encounter; functional or task-oriented which includes recreational and educational.

(1) Encounter Groups -- These groups are called human relation groups, training groups, sensitivity groups, leader development or dialogue groups. They meet a very special need in our day. They help encourage personal growth and human interaction in exciting ways. They provide useful opportunities for human beings to explore and express themselves with others. This is what Southard asserts in Your Guide to Group Experience, p. 7 .

Special leadership is required; specially prepared trainers serve as enablers to help participants:

(a) explore the whole area of human relations

(b) explore and discover new ways to behave

(c) be aware of group processes

(d) develop new skills in various areas of human interaction, e.g., conflict management, team building, organizational development, etc.

(2) Fellowship Groups -- Under this category comes the group in which we are most interested--koinonia, or growth groups. Fellowship groups are important and emphasize such points as:
(a) sense of commitment to the group life;
(b) focus on objectives to which the group gives its attention beyond mere meeting;
(c) concern for each other, including a ministry to each other 
on critical occasions;

(d) a more deliberate sharing of intimacies and personal aspects of Iife.

There is a "family feeling" of "we are in this together." The group meets regularly and tend to be very supportive. It is generally laydominated and lay-oriented.

This group enters a common discipline together:

(a) Daily prayer for each other;

(b) Daily scripture reading -- experiential application;

(c) Regular weekly worship;

(d) Disciplined study -- with more emphasis on the affective than on the cognitive;

(e) Regular service involvement, i.e., mission.

This kind of group is the level to which the church must primarily address itself. It is both the community that develops from commitment and the mission that grows out of caring.

(3) Extensional Group -- This kind of group begins with the assumption that well people can get better and the group is one arena where this can occur. It focusses on the concept that even people who are functioning adequately, who are fairly comfortable in interpersonal relationship, who may be coping with demands of daily living can still experience growth in self-actualizing efforts. Members want to free learning ability; want to attain more en joyment from living; want more spontaneity, more creativity, more autonomy, more acceptance of necessary restrictions, more joy, more productivity, more awareness and acceptance of themselves and of others--in short, want to acclerate the process of selfactualization. So claim Bates and Johnson in Group Leadership, p. 11. 
Note of Caution -- There are good reasons why the following note of caution by Southard should be taken seriously. The same danger which brought disrepute to mass evangelism threatens sensitivity groups. The same condemnation is coming upon modem exponents of emotion for its own sake. Self-disclosure can be prolonged until it is psychoanalysis without controls. The person is ripped apart and no one has time to get him together again. In Theory and Practice of Group Psychotherapy, p. 356, Dr. Irvin Yalom observes that the need for bodily expression and a friendIy embrace is carried beyond the boundaries of discretion into hitting, touching, feeling, kissing and sexual intercourse.

It is for these and other reasons that the would-be group leader must be properly trained before attempting to lead growth groups. ("Handout"-copies of excerpts from John Wallen's thoughts on "Group Concept" were given the men at this time.) (The break for intermission came at this juncture.) (See appendix D.)

Upon reconvening we went straight into our lab session. The group enjoyed participating in these exercises (pp. 15, 16), especially as the impact of their purposes came home to them in the explanations that always followed.

The last part of our session was devoted to relational Bible Study (pp. 16, 17). This new approach to Bible Study also proved to be another area of deep interest to these ministers as they. saw its potentials for their congregations. 


\section{APPENDIX B}

SUMMARY OF INSTRUCTIONAL CONCEPTS USED IN LECTURES

ON SELF-DISCLOSURE AND SELF-TRANSCENDENCE 
Summary of Instructional Concepts Used Under the Section Designated As "Self-disclosure"

\section{Communication}

Communication is not only important in general human intercourse: but also in the Divine-human relationship. The Bible illustrates this as God's communication to man. Hence communication is the greatest avenue to communion.

Intrapersonal communication--that which transpires within the individual.

Intexpersonal communication--concerned with face-to-face interaction between people who are consistently aware of each other.

Metacomminication--information about the content of the message being transmitted. It consists of nonverbal qualifiers or interpretational signals about the verbal messages--what is really meant, or how it is to be underistood.

Art of Communication

The three steps involved are:

(1) Expression--the need for clarity and conciseness to reveal thoughts and feelings precisely.

(2) Listening--three levels of listening: ears, only superficial; mind, intellectual; heart, empathetical.

(3) Response--the restatement in the listener's own words indicating that the first speaker has been clearly understood. Levels of Communication

Five levels of communication in ascending order are:

(1) Clich' conversation

(2) Reporting facts about others--gossip items 
(3) My ideas and judgments--purely intellectual

(4) My feelings--involving the emotions

(5) Peak communication--involving openness and ronesty (self-disclosure)

Variables in Communication

Some of these are:

Source--the person or persons who encode and transmit messages.

Receiver variable--the person who receives and decodes the messages. Differences in the ways that receivers decode and respond to messages must be expected.

Channel variable--a concept that is defined in at least two distinct ways: first, tools--the massmedia; second, sensory channels-human senses.

Message variable--codes representing meaning in the mind of thie person transmitting the messages. Messages may be either verbal or nonverbal. Verbal messages employ linguistic codes. (Advantages of two-way communication shown on overhead transparency)

Communication skills involve techniques such as feedback, paraphrase, congruence, ownership of message, specificity of message, redundancy of message, frame of reference, proper and accurate description of feelings.

Nonverbal communication (body language) include tactile communication or touching. Nonverbal codes do not involve actual words but in certain situations human communication occurs at a deeper level than language itself. 
Summary of Iristructional Concepts Used Under the Last Section Entitled "Self-transcendence"

Self-transcendence can be considered as a comprehensive term which expresses the demanding qualities necessary for group leadership.

The modern concepts of group leadership is in direct contrast to the social law of the 0ligarchic Imperative. Instead of one person dominating the group in a leadership role, leadership is considered as a matter of doing what is necessary for the group's functioning. Leadership Styles

Autocratic--leader determines all policy and gives orders to the group members.

Democratic--policies are set through group discussions and decisions with the leader encouraging and helping the group to interact (also called transactional). Claimed by reseachers to be the best.

Iaissez faire--very little participation by the leader.

Bureaucratic leader--leader has a frame of reference toward the group that is best characterized by the word "they." His orientation is impersonal and rule-centered. If the group behaves according to pre-established rules the leader is satisfied.

Diplomatic leader--a manipulator who can be characterized as the Machiavellian type. Uses position for personal gain and recognition; manipulates members to his desired end. Many times he enters group discussion with a "hidden agenda." Servant Leader

This is ideally exemplified in Jesus and is, therefore, the best pattern for the group leader to emulate. Six qualities of this 
type of leader can be stated as:

(1) He is commited to a shared ministry.

(2) He shows consideration for the group process.

(3) He shares resources freely.

(4) He encourages evaluation.

(5) He practices what he preaches:

(6) $\mathrm{He}$ is honest and trustworthy.

\section{Leadership Functions}

Some specific functions are: traffic directing, traffic control, blocking gossip, blocking the "there and then," blocking mind-raping, blocking inappropriate questions, blocking invasion of privacy. (The theory of Johari window is useful as a built-in safety advice, while it also illustrates the progress of the group in interpersonal communication toward the level of self-disclosure.)

Other functions include interaction catalyst, reflecting content, reflecting feeling and linking.

Qualities of Good Group Leadership

Some qualities of good group leadership are: sensitivity, sociability, credibility, supportiveness, competence, courage, composure, empathy, trust, acceptance. 


\section{APPENDIX C}

\section{EXERCISES USED IN IAB SESSIONS}

(Some of the exercises used in this section have become so popular in use by group leaders nearly everywhere that they seem to become public property to the extent that is is almost impossible to trace the original owners. However, wherever possible, credit is given.) 


\section{Day Two--Iab Session}

\section{Guessing Bxercise}

Purpose: To involve the group in a nonverbal exercise that serves as an icebreaker with excellent humor.

Materials required: Name tags with name for each member to stick or pin on back before exercise starts. If large group, divide into smaller groups and select a representative from each group to begin.

Stick name on representative and send him back to his group. Each group member is to glance at the name and, without telling him what it is, start to pantomine the name. Keep on until the representative guesses the name. Then choose another representative until all are chosen (if time permits). Examples of names that can be chosen: George Washington, Samson (Bible name), song title or historical event. The leader must be very creative to find fun names. ${ }^{1}$

\section{Exercise--Getting acquainted (Affirming)}

Purpose: To build meaningful relationship within the group on a depth-level feeling.

Instruction: Sub-group into groups of four; each participant thinks of the name of an animal to give to each member of his group.

After few minutes of thought let each participant tell why he chose that particular name for the member, e.g. I chose a teddy bear for Mary because she reminds me of a sweet, cuddling little thing; or I chose a dog for Tom because he impresses me as being faithful.

After going around ask each member what animal he would have chosen for himself and why.

${ }^{1}$ Adapted from Lyman Coleman, Serendipity (Waco, Texas: Creative Resources, 1971, pp. 26-27. 
History giving

And after six days Jesus took with him Peter and James and John, and led them up a high mountain apart by themselves; and he was transfigured before them, and his garments became glistening, intensely. white, as no fuller on earth could bleach them. And there appeared to them Elijah with Moses; and they were talking to Jesus. And Peter said to Jesus, "Master, it is well that we are here; let us make three booths, one for you and one for Moses and one for Elijah." For he did not know what to say, for they were exceedingly afraid. And a cloud overshadowed them, and a voice came out of the cloud, "This is my beloved Son; listen to him." And suddenly looking around they no longer saw any one with them but Jesus only. Mark 9:2-8

1. I think Peter wanted to build memorials on the mountain top

a. to commemorate the occasion

b. because he was nervous and wanted to make conversation

c. because he was a frustrated fisherman--really a builder at heart

d. because it had become a sacred spot to him

e.

2. If I had been in Peter's sandals my response would have been

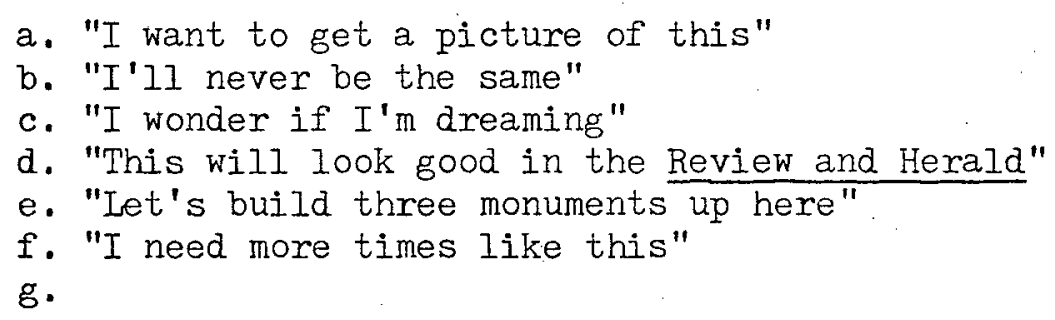

3. When I am confronted by a tense situation I usually
a. talk a mile a minute
b. clam up
c. run
d. cry

e. come unglued

f. put on my "capable person" mask

g. throw things

h.

Where does a preacher find mountain-top experiences for his soul?

Where do you find yours?

Where does your wife or husband find theirs? What is your obligation to him or her in this? 


\section{Day Three--Lab Session}

\section{Awareness exercise}

Purpose: To deal with hidden prejudices.

One aspect of growth that can be greatly facilitated by groups is an awareness of one's own hidden prejudices. This exercise offers opportunity for self-confrontation for changing these relationshipdamaging attitudes through group interaction. "The world of many people is one of walls without windows. This approach opens windows of communication through walls within and between us." Procedure

Close your eyes so that you can be more aware of your experiences. Imagine a movie screen within your mind. On it picture yourself looking into a mirror. Picture yourself going to sleep and waking up to find that you have suddenly changed (maybe to another race), or see yourself as terminally ill. How do you feel to be somebody else or to be in a different situation? How does your family feel? . . . the person who is to marry your son or daughter?

Picture yourself going back to bed again and waking up to be your true self. How do you feel about this change? Were your hidden feelings discovered? If so, how will you deal with them? If they are not dealt with they can sabotage your best efforts at social change.

This exercise is valuable for giving awareness of attitudinal blind spots in general.

Adapted from Howard Clinebell, Jr., The People Dynamic, pp. $151-152$. 
Exercise in mirroring (Affirmation):

Purpose: To learn to cooperate with another person's initiative. Procedure

Divide group into pairs. Each pair stands face to face holding hands up close to each other, palms facing but not touching. When either person begins to move partner moves with the one taking the initiative, palms still not touching. Theological reflection: Individuals learn to give up control and/or to take initiative. Relinquishing control is similar to the matter of faith, or trusting in a process that is beyond one's control. Taking initiative can also be equated or compared with exercising freedom and power that is a part of "being human."

Relational Bible Study

Worship--The Pharisee's prayer. Luke 18:9-14 (see following page).

(1) Individual study in silence

(2) Thought question dealt with individually

(3) Small group interaction, sharing within each group

(4) Prayer: each man prayed for the one on his left.

(5) Dismissal 
Worship - Luke 18:9-14

Sumarize the Pharisee's prayer in one sentence.

Were his statements factual? If not, wherein were they inaccurate? If they wexe, what was wrong with the prayer?

What does it mean to go away from church justified?

When I go to church: (More than one may apply)
a. I go to vorship
b. I go because it is my job
c. I go because people wonld think it strange if I didn't
d. It is to set an example for my family/friends
e. I enjoy it more if I'm preaching
$f$. I often feel empty but I go anywar
g. I am often impatient for it to end
$h$. I always get something, even if the sermon $I$ hear is a bumer.
i. I am always listening for good sermon ideas
j. I enjoy it most among strangers/friends

The most important lesson for me in this story is: 


\section{Day Four--Lab Session}

Exercise: My worth

Purpose: To help each member to discover himself by revealing a little of himself to the other members of the group and letting them tell him who he is.

Materials required: Workbook and pencil for each member and a box of crayons for each group.

Procedure: This exercise is in three parts:

(1) Preliminary drawing: Ask each member to choose four crayons from the box that represent four dominant colors in his life, and on a blank sheet of paper draw his world, that is, one symbol for each major part of his life. As a background for his drawing he should choose a color that represents his overall outlook on life.

(2) Small-group interaction: Move into this after ten minutes. Fach one explains his drawing to his group--choice of colors and drawing.

(3) Self-analysis: In silence, ask each member to put six words under his drawing, two words each for how he sees himself, how his parents (or spouse) see him, and how his friends see him. After a few minutes let each share the two words for each category with his group. To close join in a circle (each small group) and affirm each other in. some way.

Theological reflection: This lab smashes the illusion of superficial self-image and assures the discovery of what it means to belong to an open and honest community.

Adapted from Lyman Coleman, pp. 27-28. 
Exercise (Verbal and nonverbal): The Hive or Tribal Shout

Purpose: To build a feeling of oneness with the group and give vent to whatever feeling is inside--joy or rage.

Instruction: Six to twelve persons kneel in a circle, arm in arm tightly clustered with heads close together.

Begin the hive with a very low hum, very quietly at first and do not increase the pitch for some time.

Gradually begin to raise the volume of the hum while slowly raising the body as the volume increases. Build it very slowly while coming up, developing more and more volume in keeping with the rate of rising until all are standing upright.

Continue raising the hands to the top as the volume swells to the loudest pitch.

Theological reflection: Discuss--What does it have to do with the Christian understanding of man? Man who is capable of self-transcendence, reason and imagination still possesses a vistage of animal passions that calls out to be affirmed in the group.

Relational Bible study

Purpose: To celebrate the forgiveness of Christ over the past mistakes in your life in the company of a forgiving group.

Material: pencil and norkbook Procedure

(1) Read in silence Matt. 26:30-35, 58, 69-75 (NEB). If time permits leader can read aloud first, then each in his particular group of four, read silently, imaginatively, empathetically. Try to "fit in Peter's shoes," then write a personal letter to Peter as your closest friend. Close your eyes and think--have you ever had an experience 
like Petex's? Have you, like him, had the experience of forgiveness?

(2) Small group interaction: Let each one read his letter to his quad. Share experience if impressed, being discretionate with details.

(3) Ministry to each other: (a) Where hurt and pain have been expressed, claim the forgiveness and healing of Christ upon such memories. (b) In silence, pause and let each member think of a gift of an emotion or a character trait that he would like to give each member of his group, then give it out. e.g. Mary, I want to give you the gift of understanding to understand why God allows these circumstances to come into your life.

At the close join in a football huddle (arms over the shoulder of each other) and in this spirit of oneness and acceptance, pray for each other. 1

\section{Day Five--Lab Session}

Exercise: Affirmation

Purpose: To teach how to recognize and respond to feelings the group may have for each other in the community.

Materials required: workbook, pencil and crayon Procedure

Divide in small groups (four or five each)--three part exercise.

(1) Rotating portraits--with all in his small group. Each person in his group passes his book to the person to his right who must draw with the crayon a symbol of the gift he would like to give to the owner of the book as an expression of his wish for him for the future.

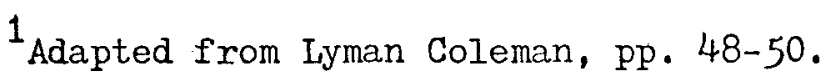


Pass it on to the next on the right urtil all are through.

(2) Interpretation: Work in silence until all is through. Then, and only then, should the meaning of each symbol be explained as the owner of each book holds it up for the drawers to explain.

(3) Celebration: Invite all small groups to come together. Ask various ones to explain what they have discovered about themselves in the process of belonging to a small group. What has been their most meaningful moment? What has been their most painful moment in the course? Where would they like to go from here? ${ }^{1}$

Relational Bible study: Mark 4:35-41 (NEB)

Purpose: To celebrate the trouble and headaches in one's life in the compary of others.

Procedure

(1) Read the passage in silence very slowly. Imagine yourself in the boat with the disciples and actually going through the experience.

(2) Pause for a moment and think over the passage once again. Picture your own life. Ask yourself two questions: In what sense am I going through a storm in my own life? At what point am I in the storm-at the beginning, in the middle or at the end?

(3) Small group interaction: Gather together in small groups of four. Ask each to share what came to mind with respect to the storm he might be going through or has recently passed through. Ask where he is at this moment in the storm.

(4) Worship. Prayer in each group.

${ }^{1}$ Adapted from Lyman Coleman, pp. 31-32. 


\section{Day Six--Lab Session}

Exercise: The Lift (Nonverbal)

Purpose: To develop the capacity to trust others.

Instruction:

Choose a partner with whom you are at a distance. One partner lies on the floor comfortably with closed eyes and fully relaxed; all limbs lie limp. The other person cradles the right wrist of his partner, lifting it very gently, slowly, while the prostrate partner gives up complete muscle control. He then lifts the entire arm in this gentle manner, then lowers it to the floor (still very gently). He then lifts the right leg similarly, and finally the head cradled with the utmost care and patience; then lowers it to the floor. Exchange positions and repeat.

Theological reflection: This experience is all about relinquishing control and becoming worthy of another's trust. This has great significance in spiritual formation. The essence of the feelings of Christ in the phrase, "Nevertheless, not My will but Thine be done" is capture in this experience. Exercising the capacity to trust others may be a step toward trusting the Source and the End of life. ${ }^{1}$

Relational Bible Study

Read silently Acts 10:9-16, 34, 44-48.

Phase One: (1) If I had the same kind of vision today, the chances are that I would find in the sailcloth (rank "1", "2", "3" etc. in the oxder of likelihood): 
a. a person of a different race

b. a person of a different faith

c. a person of a different social status

d. a person of a different moral view

e. a person of a different political view

$f$. a person of a different theological view

(2) The main thoughts I get out of this passage for today are (circle 2):

a. the conflict between the religious establishment and the Gospel

b. the way God overcomes prejudice

c. the Gospel has nothing to do with religious legalism

d. the Holy Spirit cannot be pigeonholed

e. the Church must accept whom God accepts

$f$. the universality of the Gospel

(3) The time in my own life when I experienced something like what Peter experienced was... (finish the sentence):

Phase Two: (1) The person I have the greatest difficulty accepting is (rank in order of difficulty):
a. myself as I am
b. my mate as he (or she) is
c. my children (or parents) as they are
d. my friends as they are
e. my enemies as they are

(2) If I knew that Icould count on the-support of a real Christian community, I would like to do the following about the situation (jot down two or three immediate projects):

(3) The hang up I am going to have to overcome before I can start out is... (finish this sentence): 


\section{Day Seven--Lab Session}

Exercise--Blind Walk

Purpose: To help to develop a high level of trust in a comparatively short time.

Procedure

Divide group into two, forming two circles--one near the center. Persons in the inner ring begin walking with closed eyes in any direction, cautiously at first, gradually increasing pace as confidence grows. Outer ring persons act as monitors to protect insiders from harm. Exchange places and repeat.

Theological reflection: The Bible invites us to a deeper level of trust. Discuss in pairs focussing on the issues of risk, trust and mutual accountability. ${ }^{1}$

Relational Bible Study--Priorities. Read Luke 10:38-42 (NEB). Compare these two ladies and rate yourself between them by circling the appropriate number on each line.

Mary $\underline{\text { Me }}$

Martha

1. Thinker $\begin{array}{llllllllll}1 & 2 & 3 & 4 & 5 & 6 & 7 & 8 & 9 & 10\end{array}$

Doer

2. Hungry $\begin{array}{llllllllll}1 & 2 & 3 & 4 & 5 & 6 & 7 & 8 & 9 & 10\end{array}$

3. Reflective

$\begin{array}{llll}1 & 2 & 3 & 4\end{array}$

$\begin{array}{llllll}5 & 6 & 7 & 8 & 9 & 10\end{array}$

Busy

4. Accepting

$\begin{array}{llllllllll}1 & 2 & 3 & 4 & 5 & 6 & 7 & 8 & 9 & 10\end{array}$

Anxious

5. Listener

$\begin{array}{llllllllll}1 & 2 & 3 & 4 & 5 & 6 & 7 & 8 & 9 & 10\end{array}$

Critical

6. Calm

$\begin{array}{llllllllll}1 & 2 & 3 & 4 & 5 & 6 & 7 & 8 & 9 & 10\end{array}$

Talker

7. Patient

$\begin{array}{llllllllll}1 & 2 & 3 & 4 & 5 & 6 & 7 & 8 & 9 & 10\end{array}$

8. Humble 12

9. Optimistic

$\begin{array}{llllllllll}1 & 2 & 3 & 4 & 5 & 6 & 7 & 8 & 9 & 10\end{array}$

10. Peacemaker $1 \begin{array}{llllllllll}1 & 2 & 3 & 4 & 5 & 6 & 7 & 8 & 9 & 10\end{array}$ Jittery Type Quick tempered Image conscious Fretful Quarrelsome pp. 39, 40 .

Adapted from Thomas Oden, The Intensive Group Experience, 


\section{1}

\section{Day Eight--Lab Session}

Exercise: Feedback Cards

Purpose: To facilitate honest feedback as well as to help in overcoming "clogging" (when high participants tend to crowd out the timid ones), thus increasing the flow of interaction.

Materials: Two sets of cards, two or three inches square, in colors of blue and red.

Instruction

Set cards in two separate heaps on table in center of group. When one feels a positive reaction or is sympathetic to what is being said, or wishes to respond positively, he gives a blue card to the speaker. If one feels a negative reaction or is angry he gives the speaker a red card. Speaker may request reason for getting the particular card.

Theological reflection

This exercise seeks to help persons to respect the ninth commandment-"Thou shalt not bear false witness against thy neighbor." It seeks to promote honesty in daily interpersonal transactions since we tend to indulge too often in "socialesse" (Ianguage to camouflage true feelings). 1

Relational Bible Study

Purpose: Depth-sharing for dealing with the basis for emotional wholeness from a spiritual standpoint.

Material required: Workbook and pencil Instruction:

(1) Preliminary exercise--let all read silently 1 Cor. 13:1-6 Reread meditatively to get depth meaning. Then rewrite (individually) the verse that means most to you (in your own words). Leader should 
model by sample of his own paraphrase. After ten minutes call "time" and move on to the next step.

Let each one review his paraphrase and ask himself: What must I work on in my life in order to measure up to the truth in this message? Whatever comes to mind as the need in your life at the moment jot it down under the word "Application" at the bottom of the worksheet--make it very specific. Then put down three things you could do the next week to start working on the problem. After five minutes call "time" and move on to step 2 .

(2) Small group interaction--Select moderator in each quad (should be rotated in each session).

Moderator in each group should start off with the first verse in the paraphrase and ask each one to read what he has written for his paraphrase. Moderator should listen for any key word that would be good for "gut" level discussion. After each has read his paraphrase the moderator should come back with a question that focusses the discussion on the practical aspects of the verse for his life. Then move to the next verse after five ox six minutes. Start discussion with the question that grows out of what someone has read.

(3) Depth encounter--In each small group ask each one to share what he has written as the thing he must work on in his life and the three things he is going to do about it. After each one has shared his application, gather together in a circle of love and in this posture of oneness and dependence pray specifically for each other according to the needs that have been shared. 


\section{Day Nine--Lab Session}

Exercise: Trust Circle

Purpose: To test the trust level of the group (nonverbally).

\section{Procedure}

Six to ten people form a small, fairly tight circle. One volunteer goes in the middle, is instructed to close his eyes, stand one place with feet firmly stiff and rest of body relaxed. Group must remain silent.

Volunteer must lean back and allow his body to fall into the hands of others. He is passed from hand to hand, thus feeling in sequence the support of the group. When they have expressed all they want to say to him by their hands they let him down gently on the floor. He remains as long as he wants.

Theological reflection: The group (hence the Christian community) can learn what it means to trust in God. Trusting in a human environment serves as a building block that helps to make the trustworthiness of God more meaningful.

Relational Bible Study

Session is divided into three parts: (1) preliminary exercise, (2) snall group interaction, and (3) depth encounter.

Preliminary exercise: Each person in group working on his own, read silently Heb. 10: $23-25(\mathrm{NEB})$. Jot down for each verse the symbol that applies:

* if you understand the verse clearly

? if you question the meaning

$\%$ if the verse brings special inspiration

\# if the verse gives conviction 
After you have read the verses go back and underline the two verses that you think best apply to your particular situation. Take the first verse of the two you underlined, write the number on your paper and circle it. Then read the verse again and paraphrase it, beginning with the first part and going through. Make it real in terms of your own situation wherever you are (school, work, home, church). Write it as you see it. Do the same with the second verse that you underlined. Be honest with yourself in yoir paraphrase.

Small group interaction: The object of this part is to share paraphrase with each other and discuss any misunderstanding of the passage.

From each quad choose a moderator who must see that the subject is covered. Each one in the group will read his paraphrase. Moderator must be on the alert for any unique or very important point for discussion and focus discussion on that (those) point(s). Take each verse separately.

Depth encounter: In this section each one has a chance to share what he plans to do about his discovery during the session. Each one tells why he chooses his particular answer.

The important point to drive home in this period is how each one is going to apply the study to his immediate future.

At the close the circle of Iove should pray specifically for the needs, concerns and plans that have been shared.

Adapted from Oden, pp. 38, 39. 


\section{Day Ten--Lab Session}

Exercise: Strength Bombardment

Purpose: To enable each member to point out the strength he sees in the others and to let each person share the way he sees himself. Procedure:

In each group choose one person to remain silent while the others, in turn, say what they see as the hidden strength of this one person. After each one has expressed his feelings about the person chosen this person is asked to complete these two sentences:

(a) As I see myself, my greatest strength is...

(b) As I see myself, my greatest weakness is...

Take turns to do the same with all members of the group. At the close join ir a circle of love to cloșe in an appropriate way. Relational Bible study

Spiritual encounter--Together in Celebration

Purpose: To rocall the times in your life when God revealed Himself to you in a series of unexpected events.

Materials: Workbook and pencil for each person

\section{Procedure:}

(1) Preliminary exercise--This period uses a scripture to prepare each individual for sharing after a chance to do some reflection. Read silently Acts 12:1-1? (NEB) let the imagination make the scene real and put yourself in Peter's place. After you have read the passage fill out the questionnaire on the next page. Spend ten minutes.

(2) Small. group interaction--In this section each one shares the responses of the questionnaire with the others in his group. (Sit close together and face each other in group) 
Take the first question in part 1. Wach one shares his answer and gives the reason for his choice. Do the same with the other questions. Spend about 15 minutes on this.

(3) Celebration--The purpose of this section is to recapture the spirit of the early Christian community. Combine into groups of eight. Share the answers in part 2 of the questionnaire. (The leader should set the esample in heart-to-heart sharing.) At the close join in a circle of love and celebrate together in song and/or prayer.

Questionnaire--Pa.rt 1

(1) The strangest thing about this passage for me is (circle one):
a. why Peter was locked up in the first place
b. how the church prayed and then disbelieved the answer
c. how Peter got out of prison
d. how Peter and the angel were not seen by the guards
e. why God did it

(2) The thing I get out of the passage for my life is (circle one);

a. that God has a sense of hunor

b. that God works in mysterious ways

c. that God is not limited to the laws of matter

d. that a man is immortal until his earthly work is through

e. that I can expect God to work in remarkable ways

(3) The closest I have come to escaping death was when . . .

(4) The reason why I feel I escaped death at that time was . . .
a. mere coincidence
d. God had a work for me to do
b. the laws of nature
e. because somebody prayed
c. God's providence
f. because I live right

\section{Part II}

(1) The last time I entered into a covenant of prayer with a group of people for a specific need, apart from my own selfish interests was. .

(2) The greatest thing I could ask God for right now is . . . 
APPENDIX D

HAND-OUTS 
"There is currently a revival of interest in deepening fellowship among Christians in the local church. An emphasis is being placed on the use of face-to-face groups that meet over a long enough period of time to establish rapport and cpen the gates of communication at a deeper level. These groups go by different names: Koinonia groups, prayer groups, upper-room groups, depth Bible study groups. This movement has value but, unless we are careful, it can mislead groups and is not to be found in the task groups of the church

"A call for help same the other day from a Director of Christian Education in a suburban church. 'Spiritual life groups are multiplying in our church. Many members of the church school staff are joinina small prayer groups and using involvement in them as an excuse for not attending church school planning meetings. Is there anything in print that I can lise to help them see that if they being this same concern for deenenina spiritual life to the meetings we need to have to get the work of the church done on a quality level, they can find the sane depth of fellowship and spiritual growth in these meetings?"

"She was on the right track. Fellowship that is deep and genuine comes as a by-pxoduct of joint effort on matters that have to do with the work of the Kingdom, and this includes the business affairs of the local church."

--Powell, Managing Church Business Through Group Procedures, pp. 23,24.

Explain the first two paragraphs to your partner; give your reaction to the author's comment in the last paragraph.

As you have time (ten minutes) discuss your reaction to the following propositions. Choose them in order of priority they appear to have to you.

1. Anyone who leads persons in conducting the business activities of the church shovid have as one of his aims the strengthening of the bonds that bind christians together in the Lord.

2. Human relationships and communication are completely interdependent. Improve one, and you improve another. Our atiempts to improve communication must stem from a desire to improve interpersonal relationships and to achieve mutual understanding.

3. A knowledge of, and skills in, group processes and procedures are not electives for the pastor but indispensible. Group procedures are a necessary tool for church administration, education in the church, and for Christian nurture in the congregation.

4. People change in groups. Personal growth, changes in personality and character are a product of appropriate group procedures.

"A whole series of studies shows that if one wishes to change attitudes and the subsequent behavior of a group, discussion an $\mathrm{d}$ decision where all members participate as directly as possible tends to be more effective than 'enlightment. or 'persuasion' by the lecture method." Paul Hare, Handbook of Small Groups Research.

5. Group procedures are a basic training ground for the ministry and witness of the laity. Hore they can learn skills and develop confidence for outreach. 


\title{
GROUP CONCEPTS
}

\author{
By John Wallen (1970)
}

\begin{abstract}
Although most of us spend much time in groups of one kind or another, few seen aware that a face-to-face group is something more than a collection of individuals. Notice the kinds of concepts pecple use to explain why a group did what it did. Usually they are applications of individualistic concepts such as the notives, traits and characteristics of the members of the group. Perhaps this is because you can see individuals, but you cannot see a group. Vj.sual appearances reveal no differance between five persons and a group of five. In addition, each of us is aware of his own individuality and selfhood directly and imnediately. In contrast, we cannot feel what it is like to be a group; we only experience ourselves as part of a group. Whatever the reason, the usual approach to understanding and explaining group action does not really deal with the group itscif but with individuals.
\end{abstract}

A face-to-face group can be viewed as a social system with its own qualities, processes, and structures quite apart from the nature of the members who constitute the group. Without knowing who the menbers of the group are we can still predict that each member will have had different biographical experiences, and will possess different information, opinions and objectives as well as different values, interests and style of relating to and comiunicating with others. These individual differences provide the energy that powers the group processes. However, energy can be applied creatively or destructively. Just as energy may either be generated from a controlled, sustained nuclear chain-reaction or released destructively in the uncontrolled explosion of a nuclear weapon, so human differences can fuel group accomplishment and creativity or can be expended destructively in ways that prevent accomplishment and stifle creativity.

Basic Qualities of a Face-to-Face Group

1. An expectation of shared goals: The first quality that differentiates a group of five from a collection of five persons is that the members expect it to have some common purposes, objectives or goals. The goals may be unclear, may be unstated, may be differently interpreted or defined by each member. However, each member will have an expectation of some outcome the group should be attempting to accomplish. The goal may be to solve a problem, to conduct a discussion for the educational benefit of its members, or to provide certain social and emotional satisfaction for the menbers.

2. Interdependence: Because of their expectation of shared goals the separate indivicluals become interdenendent. Although they may not recognize their interdependence, each member sees the others not just as the individual persons they are but as potential obstacles or aids in achieving what he conceives to be the groun goals. Whatever any member does affects the others and, thus, the group's progress in some way. Each nember influences and also is influenced by what occurs in the group. If a member is absent or present, silent or talkative, conciliatory or argumertative-whatever, his bohavior influences the group. 
Because they are interdependent, members cannot help influencing each other. Stated differently, members cannot avoid conmunicating. An effort not to communicate itself becomes a communication. Suppose that Jim wishes not to influence the other group members. He becomes silent. Jim's silence will be interpreted as expressing anger, agreement, boredom, fear, disapproval, interested attention. Jim's effort to avoid comnunication has, in fact, resulted in many different messages being received by various group members. Each of them is influenced by what he reads into Jim's silence.

As a member of a group you have no choice as to whether to communicate; your choice is limited to what you will attempt to communicate.

Another implication of the interdependent quality of a groun is that groups cannot avcid making decisions. When a group faces a problem or an issue it always makes some decision. The group can only choose how to make the decision; whether to make a decision is not an option.

Groups make decisions in two basic ways: (1) by public agreement, and (2) by failing to reach public agreement (i.e., by default). Thus, if a group faces the issue of whether to admit nore members it may fail to reach public agreement to admit nore members. The effect on the size of the group is exactly the same as if the group had publicly agreed not to add more members. In this sense, then, we can say that the group has decided not to admit more members. Groups, thus, can and do make decisions (by default) that satisfy none of the members and yet are carried out by all.

Because groups cannot avoid making decisions, it is useful to view whatever happens in the group as what the group has decided to do. What ever occurs in the group fulfills more function for the group members. He might almost say that whatever happens is what the group wants to happen. Let's suppose that Jim continually introduces irrelevancies into the discussion. He can change the subject only if other members follow his lead. Other members might welcome his digressions if they were bored with the topic, or feared they were getting close to open conflict, or wanted to prevent a certain decision from being agreed on. So if the other members followed Jim's irrelevancy, it would be accurate to say that the group wanted to change the subject rather than "Jin changed the subject." If constant topic-jumping were recognized as a groun problem, they could inquire into "What does it mean that we keep changing the subject?" rather than into "What's wrong with Hin that he changes the subject so much?"

Interdependence as a group quality can provide a useful frame of reference in observing a group in action. The observer reminds himself, "That this group is now doing they have decided (onenly or by default) to do. Does it move them toward sonething they wish to achieve or away from something they wish to avoid?"

I have said that interdependence is a basic quality of all groups. However, tnat should not be taken to mean that all groups are aware of it. One crucial attribute that differentiates various groups is the extent to which they are aware of and accept the interdependence of the members. 
GROUP CONCEPTS -. 3

When members of a group recognize and accept their interdependence they treat differences as evidence that some point needs to be more fully understood rather than as obstacles or as attempts of some to control others. From their ability to welcome and utilize differences they develop what Mary Parker Follett called "power with" each other (as compared to "power over" another). By contrast, the group that is not aware of or denies the interdependence of the members directs much of its energy against each other instoad of against the problem or the task. Different points of view are treated as obstacles to agreement. Moves are made to neutralize, paralyze or get rid of deviant members. Struggles for power over one another occur. Attempts to coerce or persuade each other are frequent and sharing of information and attempts at joing inquiry are infrequent.

3. Pluralistic Ignorance: This tern refers to the situation in which all persons are ignorant of the fact that al though they feel alike or hold the same belief each believes he is the only one to feel or believe what he does. A story is told of a German girl who married an Englishman. She served him tea for ten years before she discovered that both of them preferred coffee but said nothing about it because each thought the other preferred tea.

In a group every member feels confused about what's happening, but each thinks he is the only one who is confused and so says nothing. Likewise, every member in a group may be bored but believe he is the only one who feels this way.

Pluralistic ignorance poses a formidable barrier to sharing information. If any member knew that the others were confused or bored, it would be easier to admit his own confusion or boredom, but because he believes himself to be alone in his feelings it requires much more courage, willingness to risk the esteem of the others, to admit it.

When all members feel or believe alike and each assumes the others feel or believe as he does the group shares an unstated assumption. This is not pluralistic ignorance. In one training exercise for grcups each member is given a different sheet of instructions but all sheets appear identical. Typically, all members of a group assume they have identical instruction sheets. This is a shared, unstated assumption. Even'ually, one member reports something from his sheet which the others cannot find on theirs. The others later report that they were puzzled by the information because it didn't appear on their sheets, but each believed he was the only one who was puzzled and so said nothing about it. This is pluralistic ignorance. The problem cannot be solved until they discover that each does have different information and that requires that they expose the pluralistic ignorance.

Pluralistic ignorance is particularly difficult to penetrate when the shared but unstated feeling or belief strongly violates some cultural norm. In such a case group members will usually neither express their private opinions nor even expect the others to hold such opinions.

Members of a group often believe the viewpoints of the more influential and articulate members to be expressions of the opinion of the total 
group. Because of pluralistic ignorance, thus, a majority may go along with the public statements of a few rather than risk exposing their own disagreement, ignorance, confusion, feelings of inadequacy or what-have-you.

How to expose the pluralistic ignorance in the group is a problem the leader faces. Sometimes it can be done by dividing into sub-groups, maybe pairs or threesomes, for a period of discussion. In the smaller group members may feel freer to share their feelings of confusion, boredom or whatever, and thus reveal that each is not the only one feeling as he does.

4. Audience Effect: This merely refers to the comnon experience that two people often talk differently when by themselves than they do in the presence of one or more other people.

"I get along easily with Joe when we're working by ourselves, but when other people are around or we are part of a group meeting, we usually end up conpeting or arguing." Audience effect.

When member $A$ addresses a comment to member $B, A$ is also concerned about the impact on nembers $C, D$, and $E$. A's comnent then, has been affected by the presence of the others.

If Joe expresses strong anger toward Bill, Joe's anger may frighten Rita who might fear Joe would also get angry with her sometime. Realizing this, Joe holds himself in check when talking to Bill in the presence of Rita. Audience effect.

A dramatic example of audience effect is the change that occurs in the meeting of a group of middle managers when the president of the company sits in with them.

Interactions in a group, thus, take place in a public arena--in the presence of an audience. Sometimes the audience is supportive; sometimes it is antagonistic. Whatever it is, audierice effect intensifies the problem of face.

Sometimes members sharpen and exaggerate their comments because of audience effect: at other times they moderate and weaken differences. A member's comments are probably influenced as much by his awareness of those in the group that he wants to like him, those that he fears, those who have some influence over his life outside the group, etc., as by those to whom he actually appears to be speaking.

And so the basic problems the group must solve are set by these four qualities. Members must accept their interdependence and work out ways of sharing information and conducting a joint inquiry into how to attain their shared goals against the formidable obstacles to full and open communication posed by pluralistic ignorance and audience effect. 
Douglas VicGregor, an industriai psychologist at the Yassachusetts Insticute of Technology, draws upon his obsemazions of the manjgenent of large companies to characterize a well-functioning, effective, creative groun.

1. The atmosphere. . tends to be informal, comfortable, razaxed. .

2. There is a lot of discussion in wich vintually everyone participates, but it remains pertinent to the task of the group.

3. The task or objective of the group $\vdots$ weIi understood and accepti by the members. Theo vill have been free discussion of the objective at some point until it was formuleted in such a way tiat the rembers of the group could comit themselves to it.

4. The nembers listen to each other. . . . Wery jien is haaring. People do not a. exr to be afraid of jein acoish by putting forth a creative thought even if it se ins lajay extone.

5. There is disagreencnt. . . Disagreenents are not supoussos or

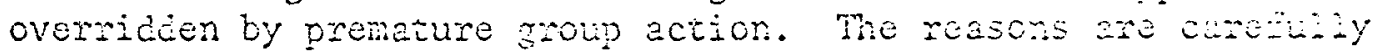
examined, and the group seeks to resolve then rathe: than to doninate the dissenter. . .

6. Nost decisions are reached by a kind of consensis in lish il is

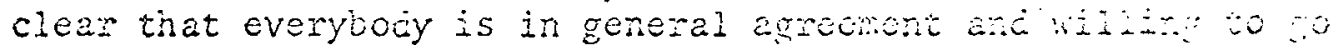
along. - . Formal voring is as a mirimm; the groug dees not accept a simple majority as a proper basis for action.

7. Cxiticism is frequent, frank, and reiativeiy conjortivia. Weac is Iittle evidence of personal attack, either opendy or in a hidden fashion...

5. People are free in exprosing their feeings as well as their icess both on the problen and on the group's oporation. . . .

9. When action is taken, clear assignments are made and acoutu.

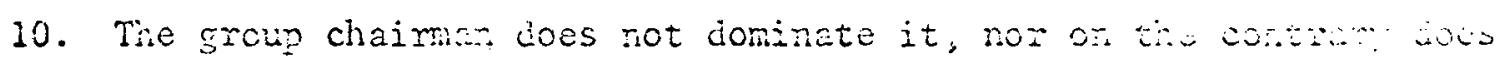

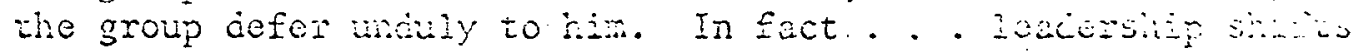
from time to time depending on the circumstances. . . a.t. is little evidence of a struggle for power as the moth onands. The issue is not who controls but how to get tho job lor.c.

11. The group is self-conscious about its own vperation.

Mcoregor, D. The human siúc o: enterprise

New York: MeGraw-liiz, 1900. 


\section{Building Group Cohesion}

The higher the level of group loyalty and group cohesion the higher the level of group energy. Leaders need to understand how to build the most cohesive groups possible.

\section{Six Suggestions:}

1. Identify your group. Build a sense of group identity by referring to it frequently as a group--Do not accentuate the "I." Avoid too much singling out of individual achievement. Talk about "we", "nur group," what "we" hope to accomplish. Build group spirit, group loyalty.

2. Build a group tradition and culture. Periods of relaxed interaction, reminiscences, memories, sharing of hopes, concerns, needs and burdens, victories and joys.

Build group tradition.

\section{I11. Baptist S. S. classes}

Highly cohesive families have traditions, memories, ways of celebrating that enrich group meaning and build loyalty.

3. Get the group to recognize good work.

Watch where compliments are being paid for good work done--endorse with your own always praising work for the contribution made to the group as a whole. Encourage social recognition, invitations to a meal.

Don't become precccupied with the high status members. The quiet, non-participating member has the greatest need for social and esteem rewards. Don't criticize his lack of apparent interest or participation. A little positive attention to the marginal individual, the potential "dead wood," will go a long way toward increasing group cohesiveness.

4. Set clear, attainable group goals . .

Long term general goals are good--but short term, achievable, measurable goals: goals for a given meeting, for this week, this month, are more likely to increase morale.

Achieving a goal rewards the group, progress reports and feedback are rewarding. The goal must be clear, within reach.

5. Give group rewards.

Reaching a clear goal is a group reward in itself. But the leader builds cohesiveness by stressing teamwork and providing group incentives-letters of commendation for the group, social affairs, recognition of a group job well done, all help.

"I could not have done it without each one of you"---is an important speech because it is important to the cohesiveness of the group and because it is true. 


\section{SUMMARY OF BASIC COMMUNICATION SKILIS \\ FOR IMPROVING INTERPERSONAL RELATIONSHIPS (Day 4)}

Objectives: You bridge the interpersonal gap as you increase the understanding you and another share. A Shared understanding means that each of you has accurate information about the other's (a) ideas and suggestions, and

(b) feelings--his intentions, emotional responses, assumptions.

The four communication skills summarized here can be helpful. . .

... if you want to encourage a spirit of joint inquiry ("Let us try to understand how each of us views this") rather than competing, blaming and fault-finding ("You're wrong: I'in right").

... if you want to increase the amount of information held in common.

... if you want to reduce the depreciation and hostility transmitted.

... if you want to lessen the likelihood of injury and hurt feelings.

1. Reception Skills: (acknowledging by checking) These responses (a) let the speaker know yau have heard him (acknowledging) and (b) that you wish to compare your understanding against his for accuracy (checking).

A. Paraphrase: (Concern with ideas and suggestions) Letting the other know what meaning his statements evoke in jou.

"Do you mean. . . (statement) . . .?"

"Is this... (statement). . an accurate understanding of your idea?"

"Would this be an example of what you mean?" (Giving a specific example)

B. Perception Check: (Concern with the person, his feelings) Describing what you perceive the other feels--tentatively and without evaluating him.

"I get the impression you'd rather not talk about this. Is that so?" "You were disappointed that they did not ask you?"

"You look like you felt hurt by my comment. Did you?"

2. Transmission Skills: These responses aim at transmitting information free of attack, accusation, depreciation and other relation-straining attributes.

A. Behavior Description: Describing specific, observable actions of others rather than stating inferences, accusations or generalizations about their motives, attitudes or personality traits.

"You bumped my cup," rather than "You never watch where you are going."

"Jim and Bill have done most of their talking and the rest of us have said very little," rather than "Jim and Bill just have to hog the spotlight."

B. Description of Feelings: Identifying your feelings by (1) name, (2) simile, (3) action urge and conveying it as information about your inner state and not as an accusation or coerciee demand against the other.

"I felt hurt when you ignored my comment," rather than "You're rude." "I feel hurt and embarrassed," rather than "You just put me down." "I'm disappointed that you forgot," rather than "You don't care about me." "I'm too angry to listen to any more now," rather than "Get out." 


\section{COMMUNICATION SKILLS}

(With Brief Description)

SKILL-devcloping one's ability to communicate his ideas, intentions and feelings accurately, and receiving communications as intended by the sender.

\section{Paraphrasing Skill}

Saying back to the speaker in your own words what you think he has said.

\section{Behavior Description Skill}

Reporting specific, obscrvable actions (i.e., waving hands or frowning, interrupting or yelling) of others without placing a value on them or demanding a change.

\section{Feeling Description Skill}

Identifying and naming the feeling one has (i.c., "I am angry with you," or "When you do that, If feel very happy.")

4. Perception Check

Check your understanding with another person as to his feeling or purpose (i.e., "I have the impression that you are bored. Is that what you intend to communicate, or have I misunderstood you?").

5. Feedback Skill

Describing to another person his behavior and the feclings you experience in response to his behavior. ("When you smiled at John, I felt relieved and less anxious.") 
GROUP NORMIS

(Day 5)

With Eriei Description

NORM-shared expectations about appropriate behaviors that help a group to do what it wuthts to cio.

1. Hereand Now Norm

Wembers talk in the present tense about what is going on in the group as it is happening right here, right now.

2. Staying with the Person Norm

The group focuses on an individual to help him work throngh an issue rather than skipping to different peopie and changing subjects.

3. Speak to the Data Norm

Talk about data generated by the members of the group, i.e. behaviors and expressed feclings. Report observablc information about behaviors of group menbers without being juigmentat.

4. Check With the Spenker Norm

Check your perceptions and guesses to sce whether or not the spaker agrecs. It may atso hitp the speaker clarify his thoughts.

5. Report Fectirys Norm

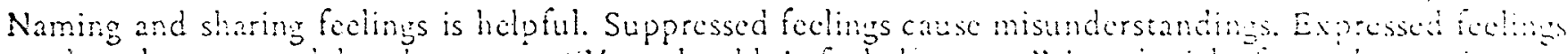

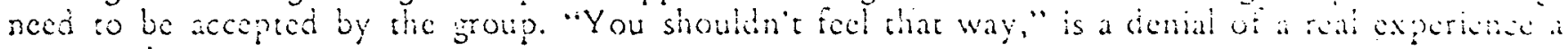
person is having.

6. Criticize like is-Nor Persons Norm

Jucigng a person, i.c., "You sure are stupid," is not a helpful stance. He cun leana and grow when you deal with his specific ideas, bchaviors or feclings.

7. Don'' Gise Aluice Norm

Rathe than rell a person what to do, consider the possib:ities to help the other person explore tits guestion and find his own answers.

8. Make No Alibis Non

Say wath is on your mind rather than sofecoing up the group with excuses and explanations.

9. Wirnindom

A collaborative or helpful stance in which everyene wins; as opposed to a win-iuse or compentine stance. 


\section{EXAMPLES OF COMMUNICATION SKILLS REOUIRED IN LEVELING}

The following examples are a few of the communication skills required for constructive leveling in teams:

1. l'uraphrasing - Stating in your own way what the other person's remarks convey to you. The other person can begin to determine whether his inessage is coming through as he intended.

Bob: "Paul should never have tried to seek funds from public agencies."

Nancy: "You mean that seeking funds is not what Paul can do best?"

Bob: "Exactly, soliciting funds is not the kind of thing Paul likes to do."

Bill: " "Fred should never have become a school principal."

Opal: "You mean he is too harsh on young people... maybe even cruel?"

Bill: $\quad$ "Oh no. I meant that he has such expensive tastes that he can't ever earn enough as a principal."

Opal: "Oh, I see. You think he should have stayed in graduate school for a doctorate to insure himself of a higher paying job?"

Bill: "Exactly! School administration is not the right job for Fred."

2. Behavior description - Reporting specific, observable actions of others without placing a value on them as right or wrong, bad or good, and without making accusations or generalizations about the other's motives, attitudes or personality traits.

Bob: "Jirn, I noticed you have talked more than others on this subject. Several times you interrupted others before they had finished."

NOT: "Jim, you're too rude."

NOT: "Jim, you always want to be in charge of the discussion."

3. Describing feelings - We usually try to describe our ideas clearly and accurately; we of ten do not try to describe our feelings clearly:

One way to identify a feeling is to name it.

"I feel angry." "I feel embarrassed." "I feel comfortable."

Another way is to use a simile.

"I feel like a small fish in a big pond."

"I feel like I have just lost my arm."

Another way is to report what action the feeling is pushing you to do.

"I feel like hugging you." "I wish I could get our of here fast."

4. Perception check - Reporting the impression you receive about another person's expressions, actions, behaviors.

"I want to understand your feelings. I get the impresson that you are angry with me. Are you?"

"I am not sure what your expression means. Have my comments hurt your feelings, irritated you or confused you?"

"This is the way I understand the ideas you have been presenting: ... Am I accurate?"

5. Stating opinions directly and to the point.

"My idea is ...."

"It seems to me...."

"In my opinion...."

6. Expressing ugreement or disagreement directly.

"I disagree with this idea . . because ...."

1 agree witit this plan.... This is why...." 
Much that goes on in a meeting is actually taking place below the visible surface; these forces have been given the name "Hidden Agendas". The group participants may be conscious of some of these; of others, they may be unconscious. The notion of 'Hidden Agenda". is a way of understanding influences at work to cause various forms of behavior in a group--both positive and negative.

When meetings frustrate, the dictum of Spinoza may be apropos: "Do not weep. Do not wax indignant. Understand."

1. Physical Probiems. A great deal of human behavior occurs because of physical feelings. A person who is uncomfortable nay disturb the harmony of a group. Lack of fresh air, uncomfortable chairs can cause much surliness. A person with a headache may push a committee to a premature soiution so that he can get home to take an aspirin.

The seating arrangement has a psychological effect on the dynamics of the group. A group discussion is more easily carried off where participants are seated in a circle than when seated row-on-row.

2. Concern for Place in the Group. The hidden agenda may take the form of a person's maneuvering and probing to find a comfortable place in the group: What do people think of me? An I being accepted? Could I possibly exert leadership and authority in this group?: Much of this kind of activity takes place early in a meeting as participants settle into their roles. It is important that all merbers experience enotional satisfaction in the group: A "blocker" in a grouv may be striking back because he is "sensitive" and therefore reads hostility inco the simplest criticism of his ideas. Honest mutual respect tends to alieviate this kind of hidden agenda. A permissive atmosphere in which remarks of all are noted and accepted by all tends to make irdividuals feel a part of the group.

3. Interpersona1 Developments in the Group. There is no way of predicting how a group of strangers called together as a group will cone to react to each other. Affinities and hostilities develop for no apparent reason. A. member who feels antagonistic to another may unconsciously opnose anything he says without knowing why. A particularly difficult person may subconsciously be taking out his hostility against authority (because of a childhood experience with an authoritarian father) against the chairman who represents such authority to him.

Friendships function the same way.A member may uncritically support another member's ideas because he likes the person proposing them.

4. Secret Hopes and Wishes of Group Members. Hidden Agendas include those things a person hopes to aclideve through the action of the group without the group knowing he is achieving them. (The conservative church treasurer, who, to the surprise of all, votes in favor of an elaborate remodeling program because he thinks this will cut off funds for a more expensive recreational hall which he couldn't conceive of supporting.)

Some come to a meeting with a "hip pocket" solution to the issue to be discussed and therefore fail to hear what others may propose. 
"Hidden Agenda" - - 2

5. Other Group Loyalties. People belong to many groups. Sometimes the problem of divided loyalties creates problems. In the mind of each person is a picture of these other groups to which he has loyalty. In essence he participates in one, but often represents another. His two purposes can coliide.

In summary, aside from the task of the announced agenda, people are motivated in group behavior on three other levels: (1) the level of purposes of which the individual is aware and which he is willing to acknowledge, (2) the level of individual purposes which are conscious but unannounced, and, (3) those purposes of which the individual himself is not aware.

What Can Be Done About Hidden Agendas?

Leland Bradford, who invented the term, offers the following suggestions:

1. Look for them. Awareness of their presence is the first step in diagnosing group difficulty originating in hidden agendas. Diagnosis is necessary for intelligent response.

2. Remember, the group is always working on two levels at once--the announced agenda, and the riddien. For this reason the group may not work as fast on the surface task as the designated leader or chaiman wishes.

3. The leader can, at times, help the group bring some of its hidden agenda to the surface. He might say, "Have we said all that needs to be said on this at this time, or should we go around the table once more so that any further thoughts can be opened up?"

4. Some hidden agenda can be laid on the table and talked about where trust has been developed. Some might hurt the group if talked about onenly. The leader needs judgment to know what a group can and cannot handle.

5. Don't scold the group about hidden agendas. lielp remove feelings of guilt about then. "We certainly could expect that each of us with our different backgrounds and interests would see thing differently. This is all part of the interesting differences that make up a group."

6. Help the group open up its blocking problems, collecting relevant data where possible and seeking a solution based on such data.

7. Help the group evaluate its progress in working together--gradually, as the group matures it will find itself able to talk freely about more of its problems and come to trust the group with conscious hidden agendas. 
In "Checking With the Speaker," page 8, checking was described as a norm, which is an agreed-upon ray of acting. Here it is described as a skill, which is how the norm is put to work.

\section{What is it?}

Perception checking is a skill employed in understanding another person. As paraphrasing is the still used in understanding the meaning of another's words, perception checking is used to understand the meaning of his actions and the feelings that cause them.

\section{Iow it works:}

First, perception checking begins with an observation of something the other person does. For cxample, John may be frowning and shaking his head as the conversation proceeds.

Second, a guess is made about the meaning of his behavior. Let's say you guess that the frowning and head shaking mean that John disagrees with you and is unhappy with the content of the discussion.

Third, you check your perception by asking him, "John, do you disageee with me, and are you unhapoy with what I said?"

Fourth, you give John a chance to say if you are accurate. He may respond by agreeing or by correcting your perception.

So, a perception check is made up of observing, guessing, checling your guess with the other person, and receiving an accuracy report from the other person. The important thing is to check your gruess. Often we do not check out our observations. We assume that our guess is right, and in many cases it is not right. We base our responding actions on the mistaken assumption, and communication breaks down.

In this case, John might reply, "I'm not unhappy with what you said. I agree with you. But I am angry" because I can't get a word in edgewise. You have been talking for the last twenty minutes." Here is a whole different issue. It may not be a pleasant one for you, but at least it is the real issue and you can deal with it if you wish.

utting it all together.

A perception check is strengthened if it is preceded by a behavior description. In other words, you tell the other person what he was doing when you observed him. Then you make your guess and the guess includes a feeling description-that is, you describe the feeling (name it) that you think is going on inside him that caused the behavior that you observed. Putting it all together, it might look like this:

"Bill, you have been facing back and forth ever since we started talking about this topic." (behavior description)

"You look as though you are nervous." (feeling description)

"Does this subject make you feel uneasy?" (perception check) 


\section{PARAPHRASING SKILL}

\section{What is it?}

Paraphrasing is restating in your own words what you heard the other person say. It is a way of revealing your understanding of the other person's comment and finding out if his remark means the same to you as it does to him. After ycil paraphrase, the speaker can affirm that you understand him, or he can see that you do not understand hin and try to clarify his ideas.

\section{Example:}

Jim: "This group doesn't really care about what I have to say."

Sue: "Do you mean that we do not listen when you speak?"

Jim: "No, you seem to listen, but then somebody always changes the subject."

Sue: "We don't stay with the issue that you are concerned about."

Jim: "That's right."

\section{The problem:}

Communication between two people is often inaccurate because they do not check to see whether or not they understand each other. A phone number is usually repeated to check accuracy. Given a complicated idea, the listener will of ten say, "I see," when he may not "see" at all. The listener may be thinking of what he is going to say next instead of listening carefully to the speaker.

What does Paraphrasing do?

1. The speaker knows you are listening and that you are interested in him.

2. Ii show's that you understand the speaker. If not, he can restate.

3. It helps the speaker clarify his thoughts. He hears his ideas in another person's words. It is like "re-reading" a statement before continuing.

4. It keeps the conversation on the subject. It encourages deepening the original thought instead of introducing new information.

5. It gives youl time to think clearly abour what you are going to do or say next.

When to use paraphrasing:

1. Often-to be sure you understand the other person's meaning. Good paraphrasing can be used many times a day in normal conversation.

2. In a crisis where the other person is excited, ovenwhelmed with happiness, frightened or angry, paraphrasing helps to understand exactly wha the crisis is in the other person's mind. Introducing new information by way of an argument or a lecture at such a time is often useless.

3. When you do not know what else to say and need time to think. Sometines a split second can make the difference between communicating or not communicating.

4. When someone shares a problem, paraphrasing helps him explore his own ideas instead of giving advice. 


\section{BEHAVIOR DESCRIPTION SKILL}

Behavior description means to report specific, observable actions of others without placing a value on them or demanding a change. We usually interpret the meaning of another person's actions and react accordingly, without describing to him what he is doing. If we misinterpret the intention of his actions, our resulting actions will be just as confusing to him.

The person whose actions you are reporting may not be aware of what he is doing. For example, he may not know that he covers his mouth with his hand when he talks. He may not be aware that he interrupes you repeatedly. On the other hand he might be aware of his actions but he does not know that you are responding to them. For example, he knows that he is repeating himself over and over again, but he does not know that you are paying any attention to that fact.

The first step in learning to give good behavior descriptions is to sharpen your ability to make precise observations. Practice describing what you see people doing, not what you think their actions mean. This may necessitate your taking an objective stance right in the midele of heated discussion. For example, while your group is talking you become aware that you are reacting negatively to one of the members. You're not sure why. So, you ask yourself, "What is he doing?" He may be interrupting, throwing the conversation off track, telling old stories that have little ralevance now, frowning a lot, or any number of other things. Until you took yourself out of the role of participant and became an observer, you did not see precisely what he was doing. As you beccme more skilled, you make observations while participating.

In reporting your observations, describe them clearly so the other person knows what you have -observed. Describe visible evidence, actions : t are open to anybody's observation, i.e., "Bill, you have been pacing back and forth ever since we stai ? talking about this topic." Not: "Bill, you sure are nervous tonight." For practice, it may be helpful to begin your description by saying, "I see that ... " or "I noticed that..." to remind yourself that you are trying to describe specific actions.

Examples of Different Kinds of Actions That May Be Described:
A. Non-Verbal Behayiors
B. Verbal Behaviors
1.. Frowning
2. Yawning
1. Interrupting
3. Pacing
4. Wiggling
2. Loud voice
5. Laughing
3. Whispering
4. Repeating
6. Gesturing, waving hands
5. Continual talking
7. Looking away, or down
6. Unfinished stacements
8. Sitting back
9. Sirting forward on edge of chair
10. Hard over mouth
11. "Pawing" another person
12. Remaining süent
7. Ignoring speaker
8. Self-contradictions
9. Judging
10. Name calling
11. Continually disagreeing
12. Changing the subject
13. Irrelevant story telling 


\section{FEELING DESCRIPTION SKILL}

One important form of communication is identifying and naming feelings. It is important because feelings build trust. Concealed feelings build suspicion and doubt. We sometimes fail to realize that our inner emotions find many different ways to be expressed. We may blush when angry or embarrassed. We may fidget or frown when confused, annoyed or even pleased. Those observing us know that we have experienced some feeling, but they do not know exactly what it is. When all they know is what they see and the feeling is not identified, doubt and suspicion may creep into the relationship. When the feeling is shared, the receiver may feel trusted and that feels good. For the person who is doing the sharing there is often a cathartic release in trusting another human being with such personal information as a feeling.

What one person feels is extremely hard for another person to know unless the feeling is named.

Naming the Feeling

I feel embarrassed...

I am angry with you...

I enjoy being here...

I feel so happy...

Naming a feeling means using a feeling word, like: joy, angry, happy, hateful, embarrassed, pleased, worried, hurt, hostile.

Indicating feelings but not naming them could look like this: "She's a wonderful person. Everyone seems to feel at home around her. I sure wish there were more people like her, and I wish I were one of them. I like people to feel like dropping in on me." In these statements we are not sure what the feelings are though many are indicated. They may be feelings of envy, loneliness, even despair. On the other hand, the speaker could be quite happy. We do not know unless the feelings are named.

\section{Helpful Hints in Lea: ning to Describe Feelings}

1. When beginning a sentence with "I feel that...," THAT usually is followed by what you THINK instead of what you FEEL.

2. If you want to describe a feeling, leave the word THAT out. Look for the verb-and raise the question as to whether it is a feeling or a "thinking."

3. Practice often identifying and describing your feelings when you are not under pressure to do so. When the need arises, you will be more proficient.

4. When listening to another person who does not name his feeling, you name it and ask if that is what he feels.

\section{EXAMPLE: "Jim, are you feeling angry right now?" or,} "Jim, do you feel good about that?"

Sharing feelings involves some risk, and risk always involves the possibility of winning or losing. But the fact remains that when trying to build meaningful relationships, sharing feelings leads to greater trust than feelings not shared. 


\section{Don't Interruot}

When a group member is talking he should not be interrupted, especially if he is sharing something perconal. Be sensitive to the person's feelings. If necessary, waive the agenda. Remember that people take oriority over prograns, and the end purpose of the group meeting is "ministry", not agenda. Sometimes the best vay to minister to an individual who is hurt is simply to listen emoathetically.

Therefore, if jt necessitates the entire cescion to minister to one person it is not to be counted as time vested. Ask him enabling questions such asi have you said all that you wanted to say about this? or, Would you like to add anything before we move on? or, Are you trying to tell us something? These and sinilar questions will encourage him to share a Iittle fore.

\section{Don't Probe}

As a leader, you should be able to differentiate between listening (enabling a person to say all that he wants to say) and probing (making a person say what he does not want to say and pssibly should not say at this time). If someone in the group starts probing the leader should tactfully step in. He may say, Let Sam tell it the way he sees it, or Haybe we should give Sam a chance to fintsh what he has to say. 


\section{Don't Give Advice}

This can be a dangerous thing to do. It is better to share a similar experience. (if someone in the group has one) and let the other person decide what he ought to do. Very often people with the least information are the quickest to give advice. The leader should be on the alert to sugrest that advisors "holà ofr" and just stick to personal experiences.

4. Don't Judge

The leader should be an enabler-one who cells out the best in another person, who sees and aftimm the best in him. Sensitive areas of disagleenent vill aow un, but love should win the test. Even if the leader diagrees with anothen membex he should afiond him the right to his own viewpojnt and release sim to think as he must.

This means, then, that instead of making conceseions or giving in, the leader can say to him: "I canrot see it the way you see it. . but I love you and I accept you just as you are and with what you believe."

This kind of loving, caring, listering and accepting is what the group is all about.

\footnotetext{
Lyman Coleman, Groups In Action (Waco, Mexas: Creative Resources, $1 9 7 1 \longdiv { , ~ p . 2 2 . ~ }$
} 


\section{THE EFFECT OF IDEAS}

TEAMWORK is INFLUENCED by the way idcas of members are received and responded to:

Work may be hindered by talking in circles, speaking in ways that belitele persons. responding in wavs that make light of ideas. Unless team members know what cach other really thinks, their work may be destructit' to ideas.

Work may be chlunced by speaking straight to the point, being honest with opinions. responding in ways that affirm the validity of ideas. Welcoming ideas will have a constructile effect on work.

KINDS OF RESPONSES we make to ideas:

Idea

Expressed

HINDERING WAYS:

Kecping quiet.

Withholding our own ideas.

Disguising our ideas with generalizations.

Expressing competitive ideas.

Changing the subject.

Moving to adjourn.

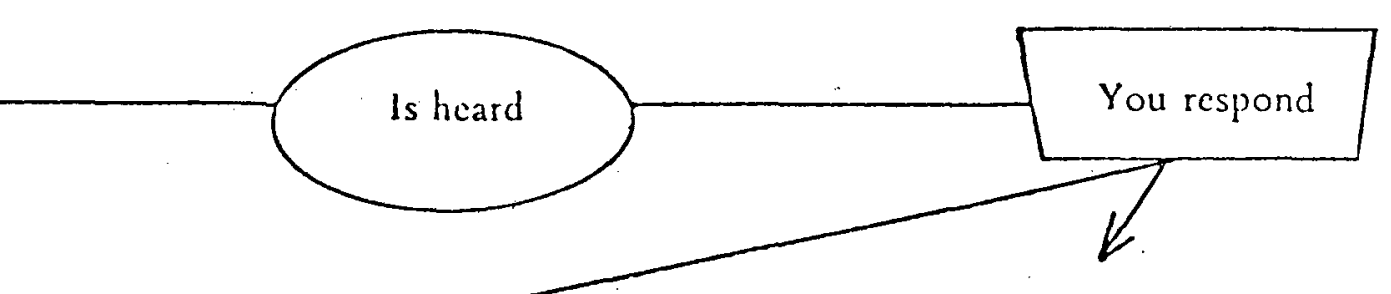

HELPING WAYS:

Building on the idea.

Asking for clarification.

Admitting we don't understand.

Admitting we don't know.

Expressing candid agreement.

Expressing candid disagrecment.

\section{THE EFFECT OF FEELINGS}

TEAMWORK is INFLUENCED by the way feelings are described, received, and responded to:

Work may be lindered, creativity blocked. encrgy drained, and productivity curtailed because feclings of hurt, rescntment, and anger are ignored, denicd. bottled up. or expressed destructively.

Work may be enhanced, productivity increased, whicn feclings are cxpressed openly, directly, and constructively and team members accept each other with their full range of human feelings.

OUR EMOTIONAL STATE SHOIIS:

(Even if you are not aware of it)

Something is said or done

\section{Anger : \\ Affection \\ Joy \\ Excitement \\ Sorrow \\ Hurt \\ Resentment \\ Love}

EMOTIONALLY

\section{PHYSICALLY}

Blushing

Wecping

Smiling

Scowling

Moving about

Looking away

Hugging

Laughing
You respond:

Emotionally and/or

Physically and/or

Verbally 
What is consensus? A shared conviction that a particular decision is the right one. Steps (though each group must work out its own style):

1. Everyone particlpates fully in discussion of the problem. Each member is responsible to state his ideas and feelings and possiole options.

2. If a member disagrees, he should feel free to express his viewpoints, feelings, reasons (not agree just to please a friend).

In this approach to decision-making, resistance is good. Members are urged to express doubts and problems. Differences should be viewed as helpful. Resistance should not be allowed to destroy the unity of the group.

3. When a person honestly feels that he can agree with one or more courses of action (even though it may not be his first choice) he so expresses himself.

The basic guidelines for consensual decision making are:

1. Avoid blindly arguing for your own individual judgments. Present your position as clearly and logically as possible, but listen to other members' reactions and consider them carefully before you press your poir.t.

2. Avoid changing your mind only to reach agreement and avoid conflict. Support only solutions with which you are at least somewhat able to a.gree. Yield only to positions that have objective and logically sound foundations.

3. Avoid "conflict-reducing" procedures such as: majority vote, tossing the coin, averaging, or bargaining in reaching decisions.

4. Seek out differences of opinion.. They are natural and expected. Try to involve everyone in the decision process. Disagreements can help the group's desicion because they present a wide range of information and opinions, thereby creating a better chance for the group to hit upon more adequate solutions.

5. Do not assume that someone must win and someone must lose when discussion reaches a stalemate. Instead, look for the next most acceptable alternative for all members. 


\section{SUGGESTIONS FOR ARRIVING AT CONSENSUS}

Since in consensus one cannot observe a standardized parliamentary procedure there are some helpful guidelines that would help the chairman in guiding toward a decision.

"1. Clearly define the purposes of the meeting and the problems to be considered.

2. Call for suggestions (not motions) for a solution of a problem. Continue discussion on all subjects until each is fully understood by every member.

3. In general, require that all opposition to any suggestion take the form of proposing an alternative suggestion. One such alternative, of course, may be to refrain from taking any action.

4. Guage the nearness of consensus occasionally by taking a preferential straw vote in which no member commits himseld to a final decision. From the results, select the most popular suggestions for continued discussion.

5. Ask all those who oppose the most populax suggestions to state the reasons for their objections, along. with proposals for modifying the popular suggestions so as to meet their objections.

6. Continue the discussior in the direction of modifying the most popular suggestions to make them acceptable to nearly all.

7. Gradually reduce the number of suggestions through the occasional straw vote.

8. Continue the modification and straw voting until one suggested course of action is acceptable to virtually all members.

9. Adopt for the present only those courses of action upon which there is almost unanimous agreement.

10. When there is an irreconcilable conflict between two methods of action, work toward the choice of one on a provisional, experimental basis."

Moody, Caesar B., Preparation for Cooperative Decision Making. The Association for Student Teaching Bulletin No, 12, 1960. 


\section{WIN/LOSE DECISION-MAKING （DAY 10）}

Win/lose situatlono pervade our culture--in law courts, politics, economics, sports, and education competition and an adversary climate prevail.

In a culture wich pleces such stress on winning it is not surprising that competitive behavior persists where it is not appropriate. In a typical committee meeting members interrupt each other to introduce their own idees. Proposels are made which go unacknowledged. Partnerships, power blocs are formed to support one vlew against enother. Porticipents are not listening to each other because they are busy thinking of ways to state a case to counter a proposal of another, or interrupting berore a spesier can clinch the sale of h1s idea. They are acting as competing individuals rather than as a collaborating group.

Athough there ere obviously some instances vhere wa/2ose is a positive lactor, it is generally destructive. Interpersonel relations ere poisoned and win/lose victories become losses for both parties--e lose/lose situation results. tions:

Bere are some possible negative results or problems in win/lose confronta..

Win/Lose maj:

1. divert time end energy from the main issues

2. delay decisions

3. create deadiocks

4. drive unasgressive members to the sidelines

5. Interfere Hiti listening

6. obstruct exploretion of more aiternetives

7. decrease or destroy sensitfvity

8. ceuse members to drop out or resign frcm comittees

9. arouse enger that disrupts a neeting

10. interfere izti empathy

21. Leave losers resentful

12. incline losers to sabotage

13. provoise personal abuse

14. cause defensiveness.

Since the predoninent trend of win/lose contests is toward lose/20se outcomes, it beccies a matter of redirecting them toward "win/xin" results. In a "win/win" result everyone comes out on top. The nore persons you have on your comittee who recognize the dangers in win/lose contests and who went to adjust the situation the more I1kelihood there is of success. What can tiney do to help?

Some meeris of aajustment:

1. Have clearly understood and agreed upon goals. These may be used to test whether iseues are relevant or not.

2. Listen. Stop yourself from working on counter-arguments while another is spenking. Take the risk of beine persuaded. 
Win/Lose Decision-Making - 2

3. Aroid absolute statements that leave no room for modification: "I think this is the best way ..." Is better then "This is the only way ..."

4. If you are planning for others, provide some means for their favolvement. There is abundant evidence that conflict is more likely to be creative and less likely to be destructive with widespread participation in decision-making.

5. Try to make decisions by consensus rather than victory of the majority.

6. Test to see that trade-offs and compromises are truly accepted by all.

7. Be alert to selling or winning strategies in others, and arold using them yourself. "Any inteilibent person can see the advantages..." would be a danger signal.

The key idea in edjusting win/lose is to strive for what is best for all rather than trying to get your wey.

--See Jonn E. Jones, J. Wh. Pfeiffer, eds. The 1973 Handbook for Croup Fecilitators, pp. $1091 \mathrm{~s}$. 
Task Functions

1. Information and Opinion Giver: Offers facts, opinions, ideas, suggestions, and relevant information to help group discussion.

2. Information and Opinion Seeker: Asks for facts, information, ideas, and feelings from other members to help discussion.

3. Starter: Proposes goals and tasks to initiation action in group.

4. Direction Giver: Develops procedure plans and focusses attention

on task to be done.

5. Summarizer: Pulls together related ideas or suggestions and restates and summarizes major points discussed.

6 Coordinator: Shows relationship among various ideas by pulling them together and organizes activities of various subgroups and members.

7. Diagnoser: Figures out sources of difficulties and blocks to progress.

8. Energizer: Stimulates a high quality of work from the group.

9. Reality Tester: Examines the practicality and workability of ideas, evaluates alternative solutions and applies them to real situations.

10. Evaluator: Compares group decisions and accomplishments with group standards and goals.

\section{Maintenance Functions}

11. Encourager of Participation: Warmly encourages everyone to participate, recognizes contributions, is opened to ideas, is responsive.

12. Harmonizer and Compromiser: Persuades members to analyze constructively their differences in opinions; tries to reconcile disagreements.

13. Tension Reliever: Eases tensions and increases enjoyment of group members by joking, breaks, and proposing fun approaches to group work. 14. Communication Helper: Shows good communication skills and makes sure each group member understands what other members are saying.

15. Evaluator of Emotional Climate: Asks members how they feel about group functions and about each other; shares his feelings about both.

16. Process Observer: Watches the process by which the group is working and uses the observations to help examine group effectiveness.

17. Standard Setter: Expresses group standards and goals to make members aware of direction of work and progress made towards goals.

18. Active Listener: Listens and serves as interested audience for members.

19. Trust Builder: Accepts and supports openness of other group members, reinforcing risk taking and encouraging individuality.

20. Interpersonal Problem Solver: Promotes open discussion of conflicts between group members to resolve conflicts and increase group togetherness.

Adapted from Johnson and Johnson, Joinirig Together (Englewood Cliffs, N.J.: Prentice-Hall, pp. 26, 27. 


\section{BIBLIOGRAPHY}

\section{Books}

Abbetmeyer, C. Four Hundred Years. St. Louis: Concordia Publishing House, 1917.

Alport, Gordon W. Patterns and Growth in Personality. New York: Holt, Rinehart and Winston, 1963.

The Analytical Greek Iexicon. New York: Harper and Brothers, n.d.

Anderson, Philip A. Church Meetings That Matter. Philadelphia: United Church Press, 1965.

Anderson, Philip, and Anderson, Phoebe. The House Church. Nashville: Abingdon Press, 1975.

Barlow, Ed. Small Group Ministry in the Contemporary Church. Missouri: Herald Publishing House, 1972.

Barnes, Albert. Barnes on the New Testament. Grand Rapids: Baker Book House, 1953. 19:330.

Barron, Frank. Creativity and Psychological Health. Princeton, New Jersey: Van Nostrand Company, 1963.

Bates, Marilyn M., and Johnson, Clarence D. Group Leadership. Colorado: Love Publishing Company, $19 \overline{72 .}$

Beyer, Hermann W. "Kavwu." Theological Dictionary of the New Testament. Grand Rapids: William B. Eerdmans Publishing Company, 1976. 3:596-602.

Beaver, R. Pierce. The Missionary Between the Times. Grand Rapids: William B. Eerdmans Publishing Company, 1962.

Berne, Eric. Games People Play. New York: Grove Press, 1964.

Beveridge, W. E. Managing the Church. London: SCM Press, 1971.

Beyerhaus, Peter, and Lefever, Henry. The Responsible Church and the Foreign Missions. Grand Rapids: William B. Eerdmans Publish-. ing Company, 1964. 
Bloom, S.; Hastings, J. T.; and Madaus, G. F. Handbook on Formative and Sumnative Evaluation of Student Learning. New York: McGraw-Hill Book Company, 1971.

Blauw, Johannes. The Missionary Nature of the Church. Grand Rapids: William B. Eerdmans Publishing Company, 1973.

Bonhoeffer, Dietrich. Life Together. Translated by John W. Doberstein. New York: Harper and Row, Publishers, 1954.

Brooks, A. E. A Critical and Exegetical Commentary on the Johanine Epistles. International Critical Commentary. Edinburgh: T. and T. Clark, 1957.

Bruniner, Emil. Dogmatics. 3 vols. Philadelphia: Westminster Press, 1962.

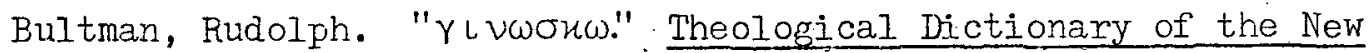
Testament. Grand Rapids: William B. Eerdnans Publishing Company, 1976. 1:689-719.

Cartwright, Dorwin, and Zander, Alvin. Group Dynamics. New York: Harper and Row, Publishers, 1953.

Casteel, John I. The Creative Role of Interpersonal Groups in the Church Today. New York: Association Press, 1968.

- Spiritual Renewal Through Personal Groups. New York: Association Press, 1957.

Clemmons, William, and Hester, Harvey. Growth Through Groups. Tennessee: Broadman Press, 1974.

Clinebell, Howard J. The People Dynamic: Changing Self and Society Through Growth Groups. New York: Harper and Row Publishers, 1972 .

Coleman, Lyman. Groups in Action. Waco, Texas: Creative Resources, 1971.

- Serendipity: A Mini Course in Personal Relationships. Waco, Texas: Creative Resources, 1971.

Congar, Yves. Lay Feople in the Church. Maryland: Newman Press, 1967.

Douglas, Paul F. The Group Workshop Way in the Church. New York: Association Press, 1956.

Douty, Mary Alice. How to Work With Church Groups. New York: Abingdon Press, 1957. 
Dow; Robert Arthur. Learning Through Encounter. Valley Forge: Judson Press, 1971.

Drummond, Lewis A. Leading Your Church in Evangelism. Nashville: Broadman Press, 1975.

Duncan, Hugh. Communication and Social Order. New York: The Bedminster Press, 1962.

Egan, Gerard, Encounter: Group Processes for Interpersonal Growth. Belmont, Calif.: Brooks-Cole Publishing Company, 1970.

Fielder, Fred. A Theory of Leadership. New York: McGraw-Hill Book Company, 1967.

Feucht, Oscar E. Everyone a Minister. St. Louis: Concordia Publishing House, 1974.

Fletcher, Kenneth R. Extend: Youth Reaching Youth. Minnesota: Augsburg Publishing fouse, 1974.

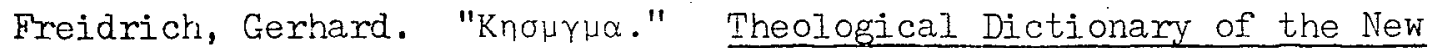
Testament. Grand Rapids: William B. Eerdmans Publishing Company, 1976. 3:714-716.

Fromm, Erich. Psychoanalysis and Religion. New Haven: Yale University Press, 1950.

Gardener, Neely D. Group Leadership. Washington, D.C.: National Training and Developinent Service Press, 1974.

Garver, W. O. What Is the Church? Nashville: Broadman Press, 1958.

Giffin, Kim, and Patton, Bobby R. Fundamentals of Interpersonal Communication. New York: Harper and Row, Publishers, 1971.

Girard, Robert G. Brethren, Hang Loose. Grand Rapids: Zondervan Publishing House, 1972.

Glasser, William. The Identity Society. New York: Harper and Row, Publishers, 1972.

Goldstein, Kurt. The Organism. New York: American Book Company, 1939.

Gordon, Thomas. Group Centered Leadership. Boston: Riverside Press, 1955.

Gorman, Alfred H. The Leader in the Group. New York: Bureau of Publications, Teachers College, 1963.

Greehy, John J. The Meaning of the Church. Dublin: Gill and Son, 1966. 
Handy, Robert T. Members One of Another. Valley Forge: Judson Press, 1959.

Haney, David. The Idea of the Laity. Grand Rapids: Zondervan Publishing House, 1973.

Harris, Irving. "Finding A Handle." In Groups That Work, pp. 11-15. Grand Rapids: Zondervan Publishing House, 1968.

Hauck, Friedrich. "Kouvwv in the New Testament." Theological Dictionary of the New Testament. Grand Rapids: William B. Eerdmans Publishing Company, 1976. 3:789-809.

Haynes, Howard B. "No Lonely Pilgrimage." In Groups That Work, pp. 101-104. Grand Rapids: Zondervan Publishing House, 1968.

Hoekendijk, J. C. The Church Inside Out. Philadelphia: Westminster Press, 1964 .

Homans, George c. The Human Group. New York: Harcourt, Brace and World, 1950.

Howard, Vernon. Your Magic Power to Persuade and Command People. Englewood Cliff's, New Jersey: Prentice-Hall, 1963.

Howard, Walden. Nine Roads to Renewal. Waco, Texas: Word Books, 1967.

- "Barriers to Friendship." In Groups That Work, pp. 30-34. Grand Rapids: Zondervan Publishing House, 1968.

Howe, Reuel. Herein Is Love. Chicago: Judson Press, 1961. - The Miracle of Dialogue. New York: Seabury Press, 1963.

Hulme, William. The Dynamics of Sanctification. Minneapolis: Augsburg Publishing House, 1968.

Inkeles, Alex. Modern Organizations. Englewood Cliffs, New Jersey: Prentice-Hall, 1964.

Jackson, Edgar N. Group Counseling. Philadelphia: Pilgrim Press, 1969.

Jackson, Samuel McCauley, ed. The New Schaff-Herzog Encyclopedia of Religjous Knowledge. 12 vols. New York: Funk and Wagnall Company, 1911.

Jackson, Norman E. Christians Learning for Christians Living. St. Louis: Christian Board of Publications, 1956.

Jacobs, Norman E. Christians Learning for Christians Living.

St. Louis: Christian Bcard of Publication, 1956. 
Johnson, David W., and Johnson, Frank P. Joining Together. Englewood Cliffs, New Jersey: Prentice-Hall, 1975.

Jourard, Sidney M. The Transparent Self. New York: Van Nostrand Company, 1964.

Keltner, John W. Elements of Interpersonal Communication. Belmont, Calif.: Wadsworth Publishing Company, 1970.

Kraemer, Hendrik. A Theology of the Laity. Philadelphia: Westminster Press, 1958.

Ladd, George Eldon. A Theology of the New Testament. Grand Rapids: William B. Eerdmans Publishing Company, 1975.

Larson, Bruce. "Honesty Is the Only Policy." In Groups That Work, pp. 20-29. Grand Rapids: Zondervan Publishing House, 1968.

Ienski, R. C. H. The Interpretation of St. James and St. Peter. Columbus, Ohio: Wartburg Press, 1945.

Leslie, R. C. Sharing Groups in the Church. Nashville: Abingdon Press, 1971 .

Lippitt, Gordon I., and Seashore, Edith. The Leader and Group Eifectiveness: New York: Association Press, 1962.

iittle, Sara. Iearning Together in the Christian Fellowship: Richmond, Virginia: John Knox Press, 1962.

Iiving Webster Encyclopedic Dictionary. Chicago: English Language Institute of America, 1975.

Luccock, Halford E. Exposition of Mark. The Interpreter's Bible. New York: Abingdon Press, 1951.

Luft, Joseph. Group Processes. Palo Alto, Calif.: National Press, 1963.

McConnel, Taylor. Group Leadership for Self Realization. New York: Mason and Lipscomb Publishers, 1974.

McCroskey, James C.; Iarson, Carl E.; and Knapp, Mark L. An Introduction to Interpersonal Communication. Englewood Cliffs, New Jersey: Prentice-Hall, 1971.

Madden, Myron C: The Power to Bless. Nashville: Abingdon Press, 1970.

Maltz, Maxwell. The Magic Power of Self-image Psychology. Englewood Cliffs, New Jersey: Prentice-Hall, 1964.

Maslow, Abraham. Toward a Psychology of Being. New York: Van Nostrand Company, 1962. 
Maxwell, Mervyn. Moving Out. Mountain View, Calif.: Pacific Press Publishing Assn., 1973.

- Tell It to the World. Mountain View, Calif.: Pacific Press Publishing Assn., 1977.

Mayers, Marvin K. Christianity Confronts Culture. Grand Rapids: Zondervan Publishing House; 1974.

Mead, George H. Mind, Self, and Society. Chicago: University of Chicago Press, 1934.

Neibuhr, Richard H. Christ and Culture. New York: Harper and Row, Publishers, 1951.

Neighbor, Ralph, and Thomas, Cal. Target Group Evangelism. Nashville: Broadman Press, 1975.

Nichol, Francis D., ed. Seventh-day Adventist Commentary. 7 vols. Washington, D.C.: Review and Herald Publishing Assn., 19531957.

$\because$ Nygren, Anders. Christ and His Church. Philadelphia: Westminster Press, $1 9 \longdiv { 4 6 . }$

Oden, Thomas C. The Intensive Group Experience. Philadelphia: Westminster Press, 1946.

O'Grady, Colm. The Church in the Theology of Karl Barth. Washington: Corpus Books, 1968.

Ohlsen, Merle M. Group Counseling. New York: Holt, Rinehart and Winston, 1970.

Oman, John B. Group Counseling in the Church. Minneapolis: Augsburg Publishing House, 1972.

Oosterwal, Gottfried. Patterns of SDA Church Growth in America. Berrien Springs, Michigar: Andrews University Press, 1976.

Oraison, Marc. Being Together: Our Relationship With Other People. New York: Doubleday and Company, 1971.

Osborne, Cecil. The Art of Understanding Yourself. Grand Rapids: Zondervan Publishing House, 1967.

Ostle, Bernard, and Mansing, Richard W. Statistics in Research. Ames: The Iowa State University Press, 1975.

Outler, Albert C. Psychotherapy and the Christian Message. New York: Harper and Brothers, 1954. 
Peterson, James A. "The Interface of Institutions and Group Process." In The Group as Agent of Change, pp. 5-17. Edited by Alfred Jacobs and Wilford Spradlin. New York: Behavioral Publications, 1974.

Powell, John. Why I Am Afraid to Tell You Who I Am. Niles, Illinois: Argus Communications, 1969.

Powell, Robert R, Managing Church Business Through Group Procedures. Englewood Cliffs, New Jersey: Prentice-Hall, 1973.

Reid, Clyde. Groups Alive--Church Alive. New York: Harper and Row, Publishers, 1969.

Richards, H. M. S. In the Beginning God. Washington, D.C. : Review and Herald Publishing Assn., 1973.

Richards, Lawrence 0. 69 Ways to Start a Study Group and Keep It Growing. Grand Rapids: Zondervan Publishing House, 1973.

Roberts, David E. Psychotherapy and a Christian View of Man. New York: Charles Scribner's Sons, 1950.

Rogness, Alvin. Captured by Mystery. Minneapolis: Augsburg Publishing House, 1966.

Sauliner, Leda, and Simard, Teresa. Personal Growth and Interpersonal Relations. Englewood Cliffs, New Jersey: Prentice-Hall, 1973.

Seifert, Harvey, and Clinebell, Howard J. Personal Growth and Social Change. Philadelphia: Westminster Press, 1952.

Siegel, Sidney. Nonparametric Statistics for the Behavioral Sciences. New York: McGraw-Hill Book Company, 1956.

Skinner, Michael. House Groups. London: Epworth Press and SPCK, 1969.

Spalding, Arthur W. Origin and History of Seventh-day Adventists. 3 vols. Washington, D.C.: Review and Herald Publishing Assn., 1961.

Stott, John R. W. Christian Mission in the Modern World. Downers Grove, Illinois: InterVarsity Press, 1975.

Taylor, Dalmas. Small Groups. Chicago: Markham Publishing Company, 1974.

Tillich, Paul. Systematic Theology. 3 vols. Chicago: University of Chicago Press, 1951. 
Trueblood, Elton. Alternative to Futility. New York: Harper and Brothers, 1948.

. "Introduction." In Groups That Work, pp. 7,8. Grand Rapids: Zondervan Publishing House, 1968.

- The Future of the Christian. New York: Harper and Row, Publishers, 1971.

- The Predicament of Modern Man. New York: Harper and Brothers, 1944.

Wegmeyer, Norman E. The Art of Christian Relationships. Minneapolis: Augsburg Publishing House, 1967.

Welch, Claud. The Reality of the Church. New York: Charles Scribner's Sons, 1958.

Wheeler, Elmer. How to Sell Yourself to Others. Englewood Cliffs, New Jersey: Prentice-Hall, 1947.

White, Ellen G. Acts of the Apostles. Mountain View, Calif.: Pacific Press Publishing Assn., 1940.

- Christian Service. Washington, D.C.: Review and Herald Publishing Assri., 1947.

- Desire of Ages. Washington, D.C.: Review and Herald

Publishing Assn., 1940. Assn., 1952. Mountain View, Calif.: Pacific Press Publishing .

- Evangelism. Washington, D.G.: Review and Herald Publishing Assn., 1946.

- Gospel Workers. Washington, D.C.: Review and Herald

Publishing Assn., 1946.

- Ministry of Healing. Mountain View, Calif.: Pacific Press

Publishing Assn., 1937.

- Patriarchs and Prophets. Mountain View, Calif.: Pacific

Press Publishing Assn., 1946.

- Testimonies for the Church. 9 vols. Mountain View, Calif.: Pacific Press Publishing Assn., 1948.

Williams, Collin. New Directions in Theology Today. Philadelphia: Westminster Press, 1968. 
Periodicals

Blum, Dennis. "Suicide--ihe Absence of Love." Review and Herald, October 20, 1977, p. 10.

Bronfenbrenner, Urie. "Nobody Home: The Erosion of the American Family." Psychology Today. 10 (May 1977): 41-43.

Campolo, Tony. Quoted in "News: Evangelicals Employ Long-abandoned Teaching Technique." These Times, October 1977, p. 6.

Cannon, John w. "Commitment." Review and Herald, September 29, 1977, p. 1.

Conn, Walter E. "Personal Identity and Creative Self-understanding." Journal of Psychology and Theology: 5 (Winter 1977): 35.

Dawe, Donald G. "The Humanity of Christ and the Future of Man." Affirmation. 1 (September 1973): 5-22.

Egan, Gerard. "Group Insearch: Propaedeutic for a Contemporary Spirituality." Listening: Journal of Religion and Culture. 12 (Spring 1977): 3-20.

Erikson, Erik. "The Problem of Ego Identity." Psychological Issues. 1 (January 1959): 47.

Evearitt, Daniel J. "Pa.ul Simon, the Only Living Boy in New York." Christianity Today, October 21, 1977, pp. 21, 22.

Hoffman, W. Michael. "Ecology, Religion and the Counterculture." Encounter. 38 (Spring 1977): 99-106.

Holt, Russel. "What on Earth Is Jesus Waiting For?" These Times, July 1975, pp. 7, 8.

Hommes, Tjoard. "Authentic Ministry." Lutheran Quarterly, February 1977 , p. 59.

Howard, Tom. "Who Am I? Who Am I?" Christianity Today, July 8, 1977, p. 12.

Hubbard, Reuben, and Hargreave, Kathy. "Don't Stop With Community Programs." Ministry, August 1977, p. 20.

Iarson, Bruce. "What Makes Theology Relational?" Faith at Work, June 1977, pp. 5, 6.

Morgan, John H. "Pastoral Ecstasy and the Authentic Self: Theological Meanings in Symbolic Distance." Pastoral Psychology. 25 (Winter 1976): 132 . 
Noll, Mark. A. "Believer-Priests in the Church: Luther's View." Christianity Today, October 16, 1973, pp. 4-8.

Radloff, R. "Social Comparison and Ability Evaluation." Journal of Experimental Social Psychology Supplement. 1 (January 1966): 6-26.

Shutz, Samuel R., and Rekers, George A. "A Proposal for Lay Mobilization in Evangelism Utilizing Behavioral Technology." Journal of Psychology and Theology. 1 (July 1973): 42-49.

Smith, Cliff. "The Encounter." Review and Herald, July 28, 1977, pp. 4,5 .

Stott, John R. W. "Unhooked Christians." Christianity Today, October 7, 1977, pp. 40-41.

van Kaam, Adrian. "Editorial." In Humanitas, June 13, 1977, p. 139. 
VITA

Name: John C. Palmer

Date and Place of Birth: January 2, 1924; Jamaica, West Indies

Undergraduate and Graduate Schools Attended:

West Indies College, Mandeville, Jamaica

Anarews University, Berrien Springs, Michigan

Degrees Awarded:

Ministerial Diploma, West Indies College, 1950

Bachelor of Theology, West Indies College, 1960

Master of Arts (Bible and Systematic Theology), Seventh-day Adventist Theological Seminary, Andrews University, Berrien Springs, Michigan, 1961

Master of Divinity, Andrews University Seminary, 1976

Doctor of Ministry, Andrews University Seminary, 1978.

Professional Experience:

1951-1958 Pastor-evangelist, West Jamaica Conference, Jamaica 1961-1971 Lay Activities Secretary, Sabbath School Secretary, Executive Secretary, and Conference Evangelist (consecutively), West Jamaica Conference, Jamaica

1972-1974 Ministerial Secretary and Union Evangelist, West Indies Union, Mandeville, Jamaica 